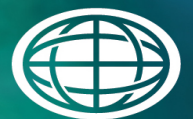

Savannah River

National Laboratory ${ }^{m}$

OPERATED BY SAVANNAH RIVER NUCLEAR SOLUTIONS

\title{
Cast Stone Formulation at Higher Sodium Concentrations
}

K. M. Fox

K. A. Roberts

T. B. Edwards

September 2013

SRNL-STI-2013-00499, Revision 0 
SRNL-STI-2013-00499

Revision 0

\section{DISCLAIMER}

This work was prepared under an agreement with and funded by the U.S. Government. Neither the U.S. Government or its employees, nor any of its contractors, subcontractors or their employees, makes any express or implied:

1. warranty or assumes any legal liability for the accuracy, completeness, or for the use or results of such use of any information, product, or process disclosed; or

2. representation that such use or results of such use would not infringe privately owned rights; or

3. endorsement or recommendation of any specifically identified commercial product, process, or service.

Any views and opinions of authors expressed in this work do not necessarily state or reflect those of the United States Government, or its contractors, or subcontractors.

\section{Printed in the United States of America \\ Prepared for \\ U.S. Department of Energy}


SRNL-STI-2013-00499

Revision 0

Keywords: Cast Stone, Hanford, LAW

Retention: Permanent

\section{Cast Stone Formulation at Higher Sodium Concentrations}

K. M. Fox

K. A. Roberts

T. B. Edwards

September 2013

Prepared for the U.S. Department of Energy under contract number DE-AC09-08SR22470.

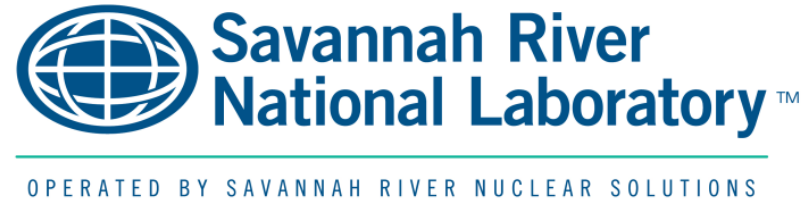




\section{REVIEWS AND APPROVALS}

\section{AUTHORS:}

K. A. Roberts, Environmental Restoration Technology

\section{TECHNICAL REVIEW:}

A. D. Cozzi, Engineering Process Development

Date

\section{APPROVAL:}

E. N. Hoffman, Manager

Date

Engineering Process Development

C. C. Herman, Manager

Date

Hanford Strategic Initiatives

S. L. Marra, Manager

Date

Environmental \& Chemical Process Technology Research Programs 


\section{ACKNOWLEDGEMENTS}

The authors would like to thank Alex Cozzi for his guidance on the design of experiments, interpretation of results, and technical review of this document. Thanks are also due to Christine Langton and Russ Eibling for their expert guidance and helpful discussions. Dr. Eibling developed the simulated salt solutions used in these experiments.

Thanks are due to many others as well. Dave Swanberg at Washington River Protection Services (WRPS) and Joe Westsik and Jeff Serne at Pacific Northwest National Laboratory (PNNL) provided helpful guidance on the Hanford Low Activity Waste (LAW) waste form program. Whitney Riley and David Best led the chemical analysis of several hundred samples for this study. Bridget Miller, Frances Williams, and Holly Hall coordinated and assisted with the laboratory experiments. Young Kim carried out the density gradient measurements. Vickie Williams, Phyllis Workman, Kim Wyszynski, Beverly Wall, Steve Crump, and Steve Moody were instrumental in completing the laboratory work. Jake Amoroso, Erich Hansen, Gene Daniel, Fabienne Johnson, and Marissa Reigel provided independent reviews of the data and calculations in this study.

Funding for this report was provided by the Department of Energy - Office of River Protection under Inter-Entity Work Order (IEWO) M0SRV00091. 


\section{EXECUTIVE SUMMARY}

A low temperature waste form known as Cast Stone is being considered to provide supplemental Low Activity Waste (LAW) immobilization capacity for the Hanford site. Formulation of Cast Stone at high sodium concentrations is of interest since a significant reduction in the necessary volume of Cast Stone and subsequent disposal costs could be achieved if an acceptable waste form can be produced with a high sodium molarity salt solution combined with a high water to premix (or dry blend) ratio. The objectives of this study were to evaluate the factors involved with increasing the sodium concentration in Cast Stone, including production and performance properties and the retention and release of specific components of interest. Three factors were identified for the experimental matrix: the concentration of sodium in the simulated salt solution, the water to premix ratio, and the blast furnace slag portion of the premix. The salt solution simulants used in this study were formulated to represent the overall average waste composition. The cement, blast furnace slag, and fly ash were sourced from a supplier in the Hanford area in order to be representative.

The test mixes were prepared in the laboratory and fresh properties were measured. Fresh density increased with increasing sodium molarity and with decreasing water to premix ratio, as expected given the individual densities of these components. Rheology measurements showed that all of the test mixes produced very fluid slurries. The fresh density and rheology data are of potential value in designing a future Cast Stone production facility. Standing water and density gradient testing showed that settling is not of particular concern for the high sodium compositions studied. Heat of hydration measurements may provide some insight into the reactions that occur within the test mixes, which may in turn be related to the properties and performance of the waste form. These measurements showed that increased sodium concentration in the salt solution reduced the time to peak heat flow, and reducing the amount of slag in the premix increased the time to peak heat flow. These observations may help to describe some of the cured properties of the samples, in particular the differences in compressive strength observed after 28 and 90 days of curing.

Samples were cured for at least 28 days at ambient temperature in the laboratory prior to cured properties analyses. The low activity waste form for disposal at the Hanford Site is required to have a compressive strength of at least 500 psi. After 28 days of curing, several of the test mixes had mean compressive strengths that were below the $500 \mathrm{psi}$ requirement. Higher sodium concentrations and higher water to premix ratios led to reduced compressive strength. Higher fly ash concentrations decreased the compressive strength after 28 days of curing. This may be explained in that the cementitious phases matured more quickly in the mixes with higher concentrations of slag, as evidenced by the data for the time to peak heat generation. All of the test mixes exhibited higher mean compressive strengths after 90 days of curing, with only one composition having a mean compressive strength of less than 500 psi. Leach indices were determined for the test mixes for contaminants of interest. The leaching performance of the mixes evaluated in this study was not particularly sensitive to the factors used in the experimental design. This may be beneficial in demonstrating that the performance of the waste form is robust with respect to changes in the mix composition.

The results of this study demonstrate the potential to achieve significantly higher waste loadings in Cast Stone and other low temperature, cementitious waste forms. Additional work is needed to elucidate the hydration mechanisms occurring in Cast Stone formulated with highly concentrated salt solutions since these reactions are responsible for determining the performance of the cured waste form. The thermal analyses completed in this study provide some preliminary insight, although the limited range of the factors in the test matrix hindered the identification of individual component effects. Future work should involve broader factor ranges to identify the roles played by each of the components in the mix via thermal analyses, analytical microscopy, and characterization of phase formation. 


\section{TABLE OF CONTENTS}

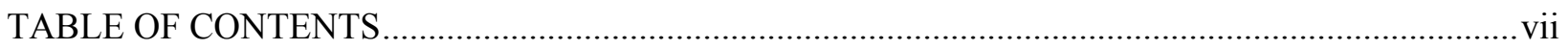

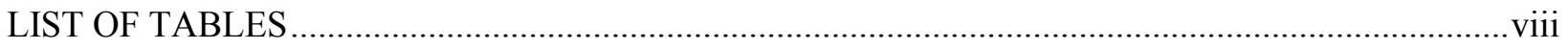

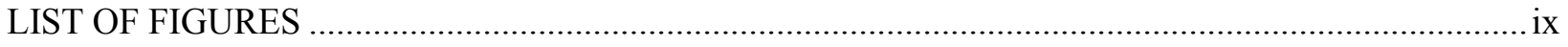

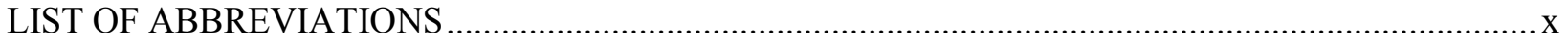

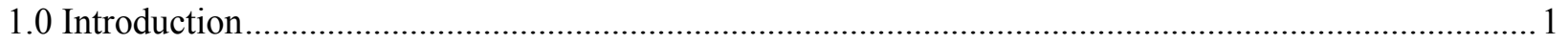

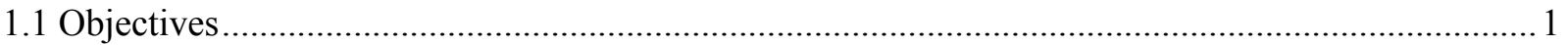

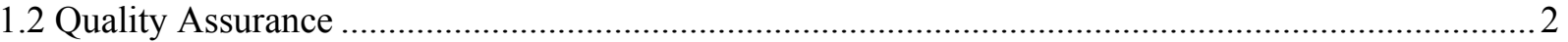

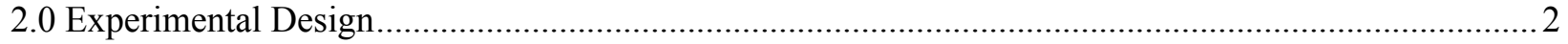

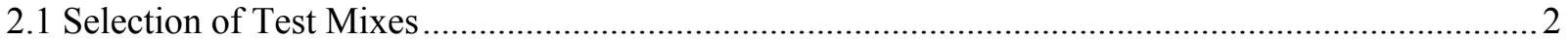

2.2 Selection, Fabrication, and Characterization of Simulants............................................................ 3

2.3 Selection, Sourcing, and Characterization of Premix .................................................................. 5

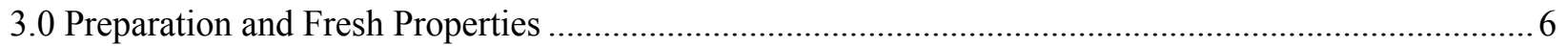

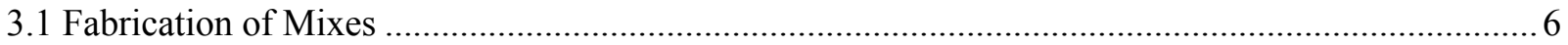

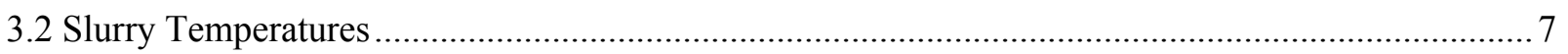

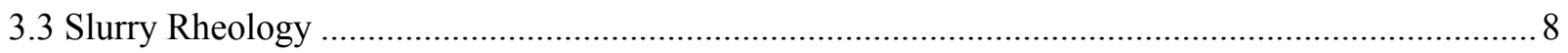

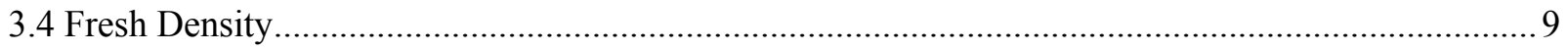

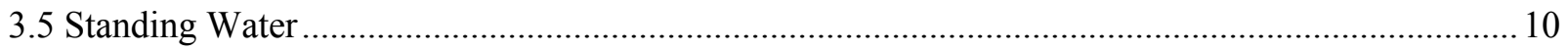

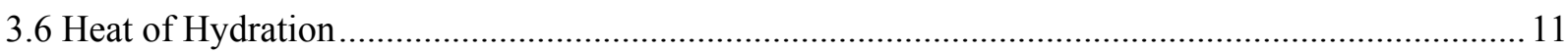

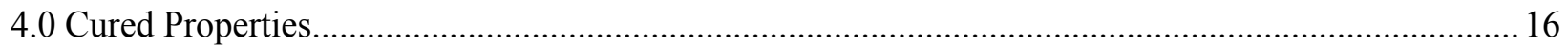

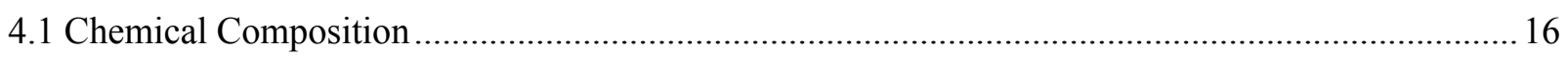

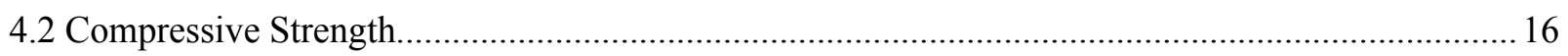

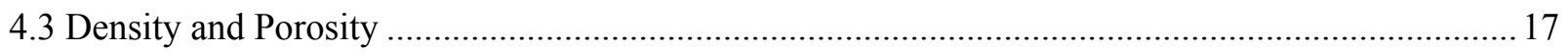

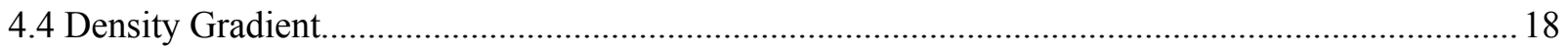

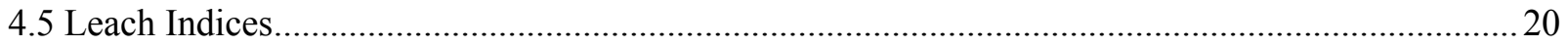

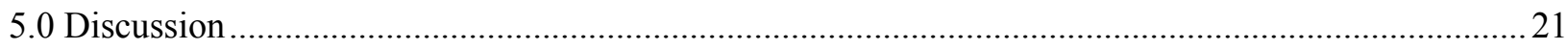

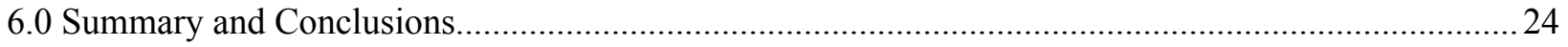

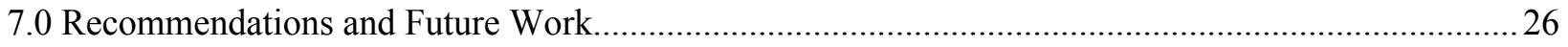

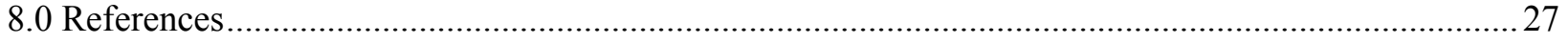

Appendix A . Chemical Composition Data for the Cured Test Mixes ..................................................A-1

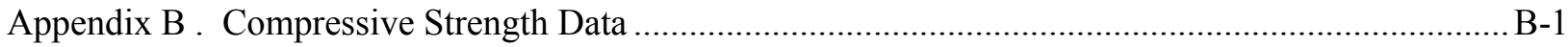

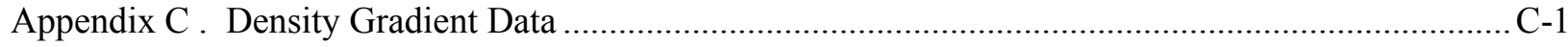

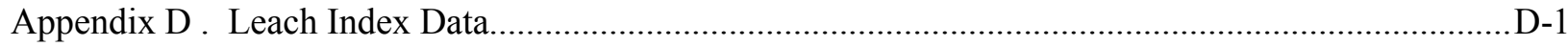

Appendix E . Least Squares Regression Analyses............................................................................ E-1 


\section{LIST OF TABLES}

Table 2-1. Factor Levels for Design of Experiments......................................................................... 3

Table 2-2. Test Mixes for High Sodium Cast Stone Study................................................................ 3

Table 2-3. HTWOS Overall Average Salt Solution Simulant. ................................................................ 4

Table 2-4. Targeted and Measured Salt Solution Simulant Compositions (mg/L)................................. 5

Table 2-5. Density and Total Solids Values for Simulated Salt Solutions. .............................................. 5

Table 2-6. Weight Percent Solids Analysis of Premix Components....................................................... 6

Table 2-7. Measured Compositions of Premix Components (wt \%) ....................................................... 6

Table 3-1. Slurry Temperature Data for Test Mixes.......................................................................... 7

Table 3-2. Flow Curve Profile Using MV2 Geometry. ....................................................................... 8

Table 3-3. Rheological Properties of the Fresh Test Mixes.................................................................. 9

Table 3-4. Measured Fresh Density Values for the Test Mixes............................................................. 10

Table 3-5. Standing Water Measurements for Test Mixes that Exhibited Free Liquids........................... 11

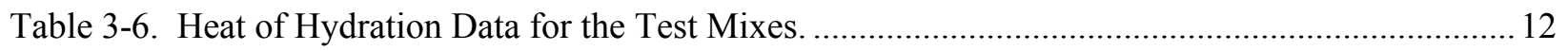

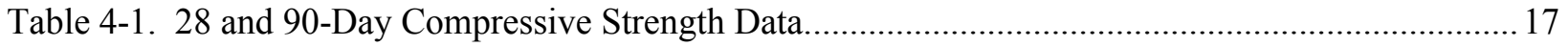

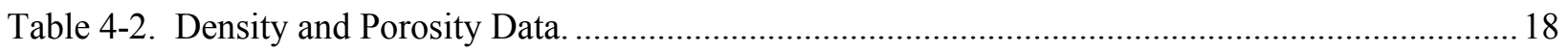

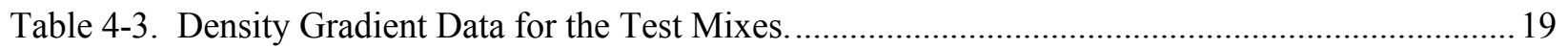

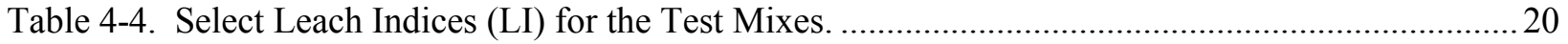




\section{LIST OF FIGURES}

Figure 1-1. Calculated grout volume as a function of sodium molarity and water to premix ratio............2

Figure 3-1. Time to Peak Heat Flow as a Function of Mix Composition................................................ 13

Figure 3-2. Peak Normalized Heat Flow as a Function of Mix Composition......................................... 14

Figure 3-3. Normalized Heat as a Function of Mix Composition......................................................... 15

Figure 5-1. Illustration of the Use of JMP's Fit Model Platform........................................................... 21 


\section{LIST OF ABBREVIATIONS}

$\begin{array}{ll}\text { GC-MS } & \text { Gas Chromatography - Mass Spectroscopy } \\ \text { HTWOS } & \text { Hanford Tank Waste Operation Simulator } \\ \text { IC } & \text { Ion Chromatography } \\ \text { ICP-OES } & \text { Inductively Coupled Plasma - Optical Emission Spectroscopy } \\ \text { LAW } & \text { Low Activity Waste } \\ \text { LI } & \text { Leach Index } \\ \text { NIST } & \text { National Institute of Standards and Technology } \\ \text { PNNL } & \text { Pacific Northwest National Laboratory } \\ \text { SPF } & \text { Saltstone Production Facility } \\ \text { SRNL } & \text { Savannah River National Laboratory } \\ \text { SRS } & \text { Savannah River Site } \\ \text { WRPS } & \text { Washington River Protection Systems } \\ \text { WTP } & \text { Hanford Waste Treatment and Immobilization Plant }\end{array}$




\subsection{Introduction}

The U.S. Department of Energy Office of Environmental Management has tasked the Savannah River National Laboratory (SRNL) and the Pacific Northwest National Laboratory (PNNL) to jointly coordinate the engagement of the broader national laboratory community to bring the scientific and technological rigor needed to evaluate and prioritize alternatives, define and execute technology development opportunities, and inform decisions that will reduce technical and programmatic risks. Through a series of meetings among the national laboratories, site field offices, and site contractors, four initiative areas were identified for possible national laboratory involvement, and these areas were prioritized such that Low-Temperature Waste Forms/Technetium Removal and Waste Feed Acceptance were the highest rated initiatives and would be started with fiscal year 2012 and 2013 funding.

A low temperature waste form known as Cast Stone is being considered to provide supplemental Low Activity Waste (LAW) immobilization capacity for the Hanford site. The Cast Stone waste form and immobilization process must be tested to demonstrate compliance with the waste acceptance criteria for the disposal facility and to demonstrate that the immobilization processes can be controlled to consistently provide an acceptable waste form product. Further, Cast Stone must be tested to provide the technical basis for understanding the long-term performance of the waste form in the disposal environment. SRNL and PNNL recently issued an assessment of the state of low temperature waste form development for Hanford and identified approaches for addressing technology needs. ${ }^{1}$ This program enhances the existing Washington River Protection Solutions (WRPS) research and development program with the national laboratories to understand the performance of Cast Stone as a LAW waste form. ${ }^{2,3}$

The flow sheet projected for Cast Stone utilizes dry reagents (collectively referred to as premix) including ordinary portland cement (binding material), fly ash, and blast furnace slag (promotes reducing environment ${ }^{4}$ ). The LAW feed is to be mixed with the solid reagents and gravity-fed into containers for curing and disposal. To date, the testing performed with either simulated waste or actual waste had a sodium concentration of around $5 \mathrm{M}^{\mathrm{a}}{ }^{\mathrm{T}}$ The Savannah River Site (SRS) Saltstone Production Facility (SPF) originally operated between 3 and $7 \mathrm{M}$ sodium. Recent proposed changes in the salt processing flow sheets could further increase the sodium concentration for low temperature waste forms. ${ }^{1}$ The current WRPS study is investigating simulated salt solutions at $5.0 \mathrm{M}$ and $7.8 \mathrm{M}$ sodium. ${ }^{2,3}$ Increasing the sodium concentration in Cast Stone has the potential to significantly reduce the overall volume of the waste form, increase waste throughput rates, and reduce the time and expense needed to complete cleanup missions.

\subsection{Objectives}

The objectives of this study were to evaluate the factors involved with increasing the sodium concentration in Cast Stone, including production and performance properties and the retention and release of specific components of interest.

The anticipated volume of the Cast Stone waste form necessary to immobilize a given mass of salt can be calculated as a function of salt solution sodium molarity and the water to premix ratio (mass basis), as shown in Figure 1-1. As the plot illustrates, a significant reduction in the

\footnotetext{
${ }^{\text {a }}$ The sodium concentration in the Waste Treatment Plant feed is limited to 4-10 M for Envelopes A, B, and C, and 2$5 \mathrm{M}$ for AZ-101 and AZ-102 supernatant. See contract between Bechtel National, Inc. and the U.S. Department of Energy, Office of River Protection, "Waste Treatment and Immobilization Plant (WTP) Contract," Contract No. DEAC27-01RV14136, Section C, Modification No. 215. The flowsheet bases for WTP state that the sodium concentration from the waste feed evaporator is about $5 \mathrm{M}$ sodium. ${ }^{5}$
} 
necessary volume of Cast Stone (and associated disposal costs) could be achieved if an acceptable waste form can be produced with a high sodium molarity salt solution combined with a high water to premix ratio. Therefore, this study targeted the compositional region shaded in Figure 1-1.

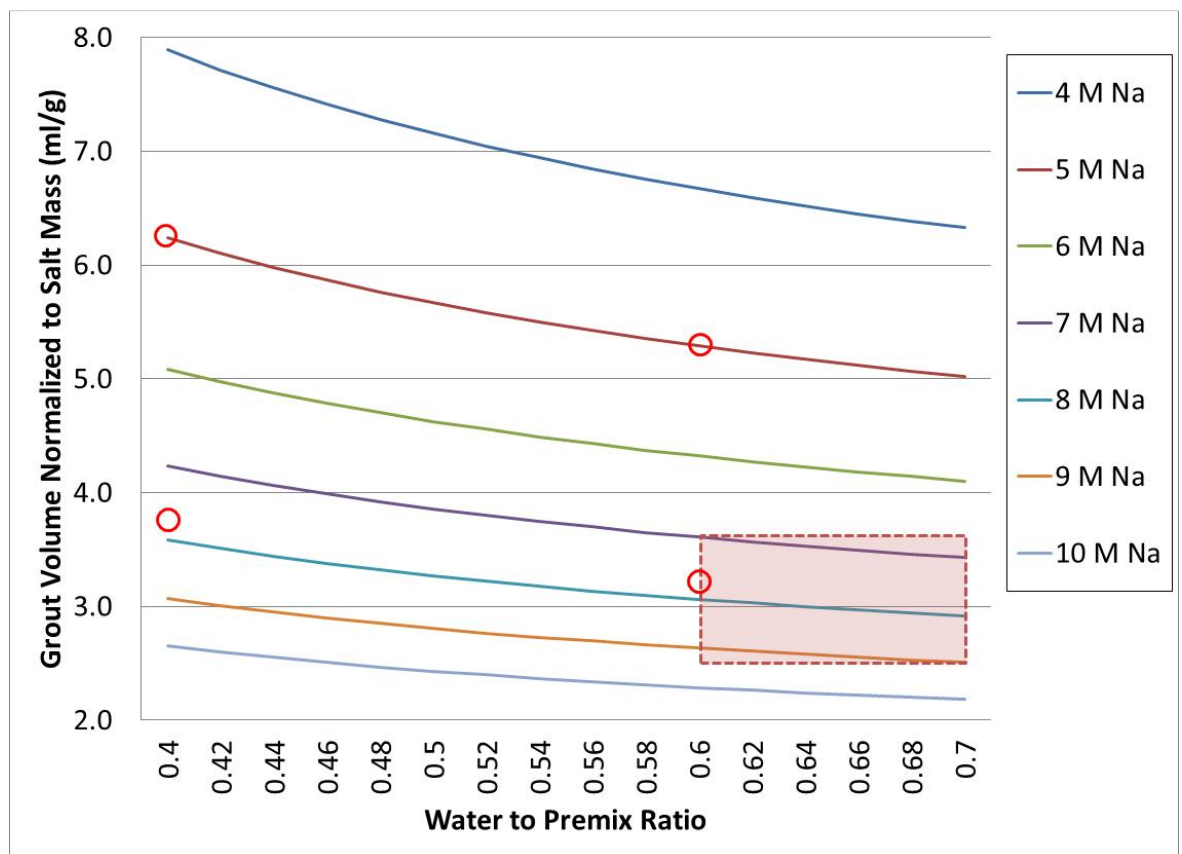

Figure 1-1. Calculated grout volume as a function of sodium molarity and water to premix ratio. Circles indicate compositions targeted as part of the concurrent SRNL/PNNL cast stone screening matrix study. ${ }^{2,3}$ Shaded area indicates region of interest for this study.

\subsection{Quality Assurance}

Requirements for performing reviews of technical reports and the extent of review are established in manual E7 2.60. SRNL documents the extent and type of review using the SRNL Technical Report Design Checklist contained in WSRC-IM-2002-00011, Rev. 2.

\subsection{Experimental Design}

\subsection{Selection of Test Mixes}

Based on the potential for Cast Stone volume reduction shown in Figure 1-1 and preliminary results of the concurrent SRNL/PNNL cast stone screening matrix study, ${ }^{2,3}$ a series of Cast Stone test mixes was selected for this high sodium concentration study. Note that the experimental matrix originally outlined in the Task Technical and Quality Assurance Plan ${ }^{6}$ was revised to allow for an improved statistical design of experiments, as described below.

Three factors were identified for the experimental matrix, as shown in Table 2-1. The concentration of sodium in the simulated salt solution was varied between 7 and $10 \mathrm{M}$, which has the largest impact on reducing Cast Stone volume for a given amount of LAW (Figure 1-1). Water to premix ratio was varied from 0.6 (current SRS SPF baseline) up to 0.7. The blast furnace slag portion of the premix was varied from the Cast Stone baseline of $47 \mathrm{wt} \%$ to a reduced level of $25 \mathrm{wt} \%$. Removal of technetium from the waste stream prior to immobilization 
is being considered in conjunction with supplemental LAW technologies to enhance the baseline Hanford Waste Treatment and Immobilization Plant (WTP) flowsheet, ${ }^{1}$ therefore, a waste form with less reducing capacity (less slag) may be both acceptable and less expensive. Additional fly ash was used when the amount of slag in the premix was reduced, and the amount of cement was held constant.

Table 2-1. Factor Levels for Design of Experiments.

\begin{tabular}{|c|c|c|c|}
\hline \hline Factor & $\begin{array}{c}\text { Salt Solution Sodium } \\
\text { Concentration (M) }\end{array}$ & $\begin{array}{c}\text { Water to Premix } \\
\text { Ratio (mass basis) }\end{array}$ & $\begin{array}{c}\text { Slag Portion of } \\
\text { Premix (wt \%) }\end{array}$ \\
\hline Low & 7.0 & 0.6 & 25 \\
\hline High & 10.0 & 0.7 & 47 \\
\hline
\end{tabular}

The factors shown in Table 2-1 were used to develop a central composite experimental design, which is shown in Table 2-2. This design utilizes the three factors each at three values. It also includes six replicates of the centroid test mix, highlighted in the table, which will allow for an analysis of the reproducibility of the fabrication and characterization methods used in the study.

Table 2-2. Test Mixes for High Sodium Cast Stone Study.

\begin{tabular}{|c|c|c|c||}
\hline Identifier & $\begin{array}{c}\text { Sodium } \\
\text { Molarity (M) }\end{array}$ & $\begin{array}{c}\text { Water to } \\
\text { Premix Ratio }\end{array}$ & $\begin{array}{c}\text { Dry Blend (wt \%) } \\
\text { Cement:Fly Ash:Slag }\end{array}$ \\
\hline NWS-01 & 8.5 & 0.65 & $8: 56: 36$ \\
\hline NWS-02 & 7.0 & 0.65 & $8: 56: 36$ \\
\hline NWS-03 & 10.0 & 0.70 & $8: 67: 25$ \\
\hline NWS-04 & 10.0 & 0.60 & $8: 45: 47$ \\
\hline NWS-05 & 8.5 & 0.65 & $8: 56: 36$ \\
\hline NWS-06 & 7.0 & 0.70 & $8: 45: 47$ \\
\hline NWS-07 & 10.0 & 0.60 & $8: 67: 25$ \\
\hline NWS-08 & 8.5 & 0.65 & $8: 56: 36$ \\
\hline NWS-09 & 7.0 & 0.70 & $8: 67: 25$ \\
\hline NWS-10 & 8.5 & 0.60 & $8: 56: 36$ \\
\hline NWS-11 & 8.5 & 0.70 & $8: 56: 36$ \\
\hline NWS-12 & 8.5 & 0.65 & $8: 56: 36$ \\
\hline NWS-13 & 10.0 & 0.65 & $8: 56: 36$ \\
\hline NWS-14 & 8.5 & 0.65 & $8: 45: 47$ \\
\hline NWS-15 & 10.0 & 0.70 & $8: 45: 47$ \\
\hline NWS-16 & 8.5 & 0.65 & $8: 56: 36$ \\
\hline NWS-17 & 8.5 & 0.65 & $8: 67: 25$ \\
\hline NWS-18 & 7.0 & 0.60 & $8: 45: 47$ \\
\hline NWS-19 & 7.0 & 0.60 & $8: 67: 25$ \\
\hline NWS-20 & 8.5 & 0.65 & $8: 56: 36$ \\
\hline * Replicates & \multicolumn{2}{|l}{} \\
\hline
\end{tabular}

\subsection{Selection, Fabrication, and Characterization of Simulants}

The salt solution simulants used in this study were derived from the Hanford Tank Waste Operation Simulator (HTWOS) to represent the overall average composition. The HTWOS overall average composition ${ }^{2}$ is given in Table 2-3 using concentrations in terms of moles of species per mole of Na. This salt simulant composition was modified to produce 7.0, 8.5, and 
10.0 M Na simulants. The phosphate and fluoride levels were reduced to minimize the amount of insoluble fluorophosphate formation.

Table 2-3. HTWOS Overall Average Salt Solution Simulant. ${ }^{2}$

\begin{tabular}{|c|c|}
\hline $\begin{array}{c}\text { Waste } \\
\text { Constituent }\end{array}$ & $\begin{array}{c}\text { Concentration } \\
\text { (moles / mole Na) }\end{array}$ \\
\hline $\mathrm{Al}$ & 0.061 \\
\hline $\mathrm{K}$ & 0.007 \\
\hline $\mathrm{Na}$ & 1.000 \\
\hline $\mathrm{Cl}^{-}$ & 0.008 \\
\hline $\mathrm{CO}_{3}{ }^{2-}$ & 0.056 \\
\hline $\mathrm{F}^{-}$ & 0.006 \\
\hline $\mathrm{NO}_{2}{ }^{-}$ & 0.113 \\
\hline $\mathrm{NO}_{3}{ }^{-}$ & 0.324 \\
\hline $\mathrm{PO}_{4}{ }^{3-}$ & 0.010 \\
\hline $\mathrm{SO}_{4}{ }^{2-}$ & 0.017 \\
\hline $\mathrm{TOC} \mathrm{Total}_{\mathrm{Free} \mathrm{OH}}$ & 0.015 \\
\hline $\mathrm{Cr}$ & 0.312 \\
\hline $\mathrm{Ni}$ & $4.31 \mathrm{E}-03$ \\
\hline $\mathrm{Pb}$ & $6.47 \mathrm{E}-04$ \\
\hline $\mathrm{Cd}$ & $5.12 \mathrm{E}-05$ \\
\hline $\mathrm{I}$ & $3.20 \mathrm{E}-05$ \\
\hline \multicolumn{2}{|l}{} \\
\hline
\end{tabular}

Chromium and iodine concentrations in the salt solution simulants were adjusted to support leaching experiments. Targeted concentrations were selected such that measureable values were expected to result (i.e., measured values would be above detection limits) while attempting to avoid unrealistically high concentrations that may falsely represent waste form performance. Chromium concentrations that corresponded to the HTWOS $95^{\text {th }}$ percentile composition were selected $\left(4.3 \times 10^{-3} \mathrm{M} / \mathrm{M} \mathrm{Na}\right)$ for both this study and the concurrent screening matrix study. ${ }^{2,3}$ Iodine concentrations were selected based on an anticipated detection limit of $0.5 \mathrm{ppb}$ in the leachate and to allow the reporting of a leach index for iodine of at least 11 at this detection limit. Note however that these limitations resulted in a targeted iodine concentration in the simulated salt solutions that was approximately two orders of magnitude higher than the expected concentration. ${ }^{2}$ Future testing at more realistic iodine concentrations may be beneficial.

The simulated salt solutions were prepared using the method described in Appendix A of Russell et al. ${ }^{7}$ The presence of undissolved solids was observed in all of the simulants due to their high salt concentrations. It was assumed that the future Cast Stone production facility would have the ability to process this material. Impacts of the undissolved solids on the performance of the Cast Stone waste form were evaluated as part of this study.

Targeted and measured compositions of the salt solution simulants are given in Table 2-4. Compositions were measured using Inductively Coupled Plasma - Optical Emission Spectroscopy (ICP-OES) analyses for cations and Ion Chromatography (IC) analyses for anions. Analyses of the total solutions were performed using samples diluted with deionized water such that the solids were dissolved. Analyses of the supernatants were performed using decanted and filtered samples. A review of the data presented in Table 2-4 shows that the measured 
concentrations met their targeted values within reason for the purposes of this study. The density and total solids values for each simulated salt solution are reported in Table 2-5.

Table 2-4. Targeted and Measured Salt Solution Simulant Compositions (mg/L).

\begin{tabular}{|c|c|c|c|c|c|c|c|}
\hline \multicolumn{2}{|c|}{ Total } & $\overline{\mathrm{Al}}$ & $\mathrm{Cr}$ & $\bar{K}$ & $\bar{P}$ & $\bar{S}$ & Si \\
\hline \multirow{2}{*}{$7.0 \mathrm{M} \mathrm{Na}$} & Targeted & 11600 & 1565 & 1795 & 2125 & 3860 & 0 \\
\hline & Measured & 11450 & 1025 & 2180 & 2015 & 2965 & 1 \\
\hline \multirow{2}{*}{$8.5 \mathrm{M} \mathrm{Na}$} & Targeted & 14080 & 1900 & 2180 & 2580 & 4687 & 0 \\
\hline & Measured & 12950 & 1210 & 2485 & 2195 & 3530 & 2 \\
\hline \multirow{2}{*}{$10.0 \mathrm{M} \mathrm{Na}$} & Targeted & 16570 & 2236 & 2565 & 3035 & 5514 & 0 \\
\hline & Measured & 15350 & 1290 & 2885 & 2565 & 3850 & $<1$ \\
\hline \multicolumn{2}{|c|}{ Total } & $\mathbf{F}^{-}$ & $\mathrm{Cl}^{-}$ & $\mathrm{NO}_{2}^{-}$ & $\mathrm{NO}_{3}^{-}$ & $\mathrm{SO}_{4}{ }^{2-}$ & $\mathrm{PO}_{4}^{3-}$ \\
\hline \multirow{2}{*}{$7.0 \mathrm{M} \mathrm{Na}$} & Targeted & 840 & 2095 & 36380 & 140800 & 11565 & 6515 \\
\hline & Measured & $<100$ & 2050 & 37250 & 139000 & 11150 & 734 \\
\hline \multirow{2}{*}{$8.5 \mathrm{M} \mathrm{Na}$} & Targeted & 1021 & 2543 & 44180 & 170970 & 14040 & 7910 \\
\hline & Measured & $<100$ & 2490 & 45050 & 168000 & 13550 & 1094 \\
\hline \multirow{2}{*}{$10.0 \mathrm{M} \mathrm{Na}$} & Targeted & 1201 & 2992 & 51980 & 201140 & 16520 & 9310 \\
\hline & Measured & $<100$ & 3060 & 54700 & 199500 & 14850 & 2170 \\
\hline \multicolumn{2}{|c|}{ Supernatant } & $\mathbf{A l}$ & $\mathrm{Cr}$ & $\bar{K}$ & $\mathbf{P}$ & $\mathrm{S}$ & $\overline{\mathrm{Si}}$ \\
\hline \multirow{2}{*}{$7.0 \mathrm{M} \mathrm{Na}$} & Targeted & 11600 & 1565 & 1795 & 2125 & 3860 & 0 \\
\hline & Measured & 11450 & 1380 & 2855 & 597 & 4365 & 4 \\
\hline \multirow{2}{*}{$8.5 \mathrm{M} \mathrm{Na}$} & Targeted & 14080 & 1900 & 2180 & 2580 & 4687 & 0 \\
\hline & Measured & 13600 & 1725 & 3480 & 644 & 4665 & 5 \\
\hline \multirow{2}{*}{$10.0 \mathrm{M} \mathrm{Na}$} & Targeted & 16570 & 2236 & 2565 & 3035 & 5514 & 0 \\
\hline & Measured & 16150 & 2060 & 4265 & 579 & 3400 & 6 \\
\hline \multicolumn{2}{|c|}{ Supernatant } & $\mathrm{F}^{-}$ & $\mathrm{Cl}^{-}$ & $\mathrm{NO}_{2}^{-}$ & $\mathrm{NO}_{3}^{-}$ & $\mathrm{SO}_{4}{ }^{2-}$ & $\mathrm{PO}_{4}^{3-}$ \\
\hline \multirow{2}{*}{$7.0 \mathrm{M} \mathrm{Na}$} & Targeted & 840 & 2095 & 36380 & 140800 & 11565 & 6515 \\
\hline & Measured & $<100$ & 2100 & 38050 & 142500 & 11450 & 738 \\
\hline \multirow{2}{*}{$8.5 \mathrm{M} \mathrm{Na}$} & Targeted & 1021 & 2543 & 44180 & 170970 & 14040 & 7910 \\
\hline & Measured & $<100$ & 2565 & 46400 & 174500 & 12400 & 762 \\
\hline \multirow{2}{*}{$10.0 \mathrm{M} \mathrm{Na}$} & Targeted & 1201 & 2992 & 51980 & 201140 & 16520 & 9310 \\
\hline & Measured & $<100$ & 3090 & 55950 & 203500 & 8960 & 559 \\
\hline
\end{tabular}

Table 2-5. Density and Total Solids Values for Simulated Salt Solutions.

\begin{tabular}{|c|c|c|}
\hline $\begin{array}{c}\text { Salt } \\
\text { Solution }\end{array}$ & $\begin{array}{c}\text { Density } \\
(\mathbf{g} / \mathbf{m L})\end{array}$ & $\begin{array}{c}\text { Total Solids } \\
\text { (wt \%) }\end{array}$ \\
\hline $7.0 \mathrm{M} \mathrm{Na}$ & 1.31 & 35.4 \\
\hline $8.5 \mathrm{M} \mathrm{Na}$ & 1.37 & 41.2 \\
\hline $10.0 \mathrm{M} \mathrm{Na}$ & 1.42 & 46.4 \\
\hline
\end{tabular}

\subsection{Selection, Sourcing, and Characterization of Premix}

The cement, blast furnace slag, and fly ash used in this study were sourced from a supplier in the Hanford area via PNNL and shipped to SRNL for use. The materials were characterized by heating at $800{ }^{\circ} \mathrm{C}$ for one hour to determine weight percent solids (Table 2-6), and by dissolution and ICP-OES elemental analysis to determine composition (Table 2-7). The results are typical of 
these materials and are reported here for reference. ${ }^{a}$ The premix materials were batched at the appropriate ratios for each mix in the test matrix and stored in sealed plastic bags. The premix was blended by manually shaking the bags.

Table 2-6. Weight Percent Solids Analysis of Premix Components.

\begin{tabular}{|c|c|}
\hline Component & wt \% Solids \\
\hline Cement & $97.5 \%$ \\
\hline Fly Ash & $99.6 \%$ \\
\hline Slag & $98.2 \%$ \\
\hline
\end{tabular}

Table 2-7. Measured Compositions of Premix Components (wt \%).

\begin{tabular}{|c|c|c|c|c|c|c|}
\hline \hline Component & $\mathbf{A l}_{2} \mathbf{O}_{3}$ & $\mathbf{B a O}$ & $\mathbf{C a O}$ & $\mathbf{C r}_{2} \mathbf{O}_{3}$ & $\mathbf{C u O}$ & $\mathbf{F e}_{2} \mathbf{O}_{3}$ \\
\hline Cement & 4.7 & 0.04 & 65.9 & 0.02 & 0.04 & 3.45 \\
\hline Fly Ash & 16.6 & 0.56 & 12.1 & - & 0.02 & 6.00 \\
\hline Slag & 12.7 & 0.04 & 43.2 & - & 0.00 & 0.82 \\
\hline Component & $\mathbf{K}_{2} \mathbf{O}$ & $\mathbf{M g O}$ & $\mathbf{M n O}_{2}$ & $\mathbf{N a}_{2} \mathbf{O}$ & $\mathbf{P}_{2} \mathbf{O}_{5}$ & $\mathbf{S O}_{4}{ }^{2-}$ \\
\hline Cement & 0.33 & 0.64 & 0.08 & 0.33 & 0.06 & 3.56 \\
\hline Fly Ash & 1.82 & 4.15 & 0.08 & 3.89 & 0.27 & 0.67 \\
\hline Slag & 0.52 & 3.90 & 0.23 & 0.21 & 0.00 & 4.56 \\
\hline Component & $\mathrm{SiO}_{2}$ & $\mathrm{SrO}$ & $\mathbf{T i O}_{2}$ & $\mathbf{Z n O}$ & $\mathbf{Z r O}_{2}$ & Total \\
\hline Cement & 20.2 & 0.15 & 0.24 & 0.17 & 0.00 & 99.9 \\
\hline Fly Ash & 51.9 & 0.30 & 0.81 & - & 0.03 & 99.2 \\
\hline Slag & 33.0 & 0.06 & 0.39 & - & 0.02 & 99.6 \\
\hline
\end{tabular}

(-) indicates below detection limit

\subsection{Preparation and Fresh Properties}

\subsection{Fabrication of Mixes}

The test mixes were prepared by mixing the appropriate masses of simulated salt solution and premix in the laboratory. ${ }^{b}$ The salt solution was batched into a three liter plastic pitcher. The pitcher was set under a mixer (Caframo, Ltd.) with an impeller consisting of four elliptical blades. The impeller was placed as close as practical to the bottom and side of the pitcher without making contact. The mixer was started at a speed of $400 \mathrm{rpm}$, and the premix was gradually added from its bag to the salt solution over a period of 1-2 minutes. Agglomerates of the premix material were observed on the bottom of the pitcher after mixing NWS-01. Therefore, for the remaining mixes, the mixer speed was increased incrementally as the premix was added, up to a final speed of $850-950 \mathrm{rpm}$. This was successful in minimizing unincorporated solids. Mixing continued for a total of about 10 minutes for each composition. A paddle was used as a baffle to break the vortex at higher mixing speeds in order to minimize air entrainment.

\footnotetext{
${ }^{a}$ Note that while the compositions are reported here as common oxides, these representations may not be the actual forms (e.g., iron may be reduced, sulfur may be sulfides, etc.).

${ }^{\mathrm{b}}$ Details of all the laboratory work are recorded in laboratory notebook SRNL-NB-2013-00013.
} 
Immediately after mixing, samples were poured for rheology, density, and heat of hydration measurements, ${ }^{a}$ and a series of plastic molds was filled to support measurements of bleed water, compressive strength, and leach indices. The samples for cured properties measurements were placed into zip top plastic bags containing a moist towel to maintain a humid curing environment.

The samples were cured for at least 28 days at ambient temperature in the laboratory prior to cured properties analyses. Measurements of the fresh and cured properties of the test mixes are described in the following sections. In each case, the data presented will be further reviewed as part of the statistical analysis later in this report.

\subsection{Slurry Temperatures}

An increase in temperature of the slurry may indicate early hydration reactions, and can potentially be linked to other properties of the waste form. The temperature of the salt solution for each test mix was measured with an immersed Type $\mathrm{K}$ thermocouple prior to adding the premix. The temperature was measured again while mixing after all of the premix had been added to the salt solution. A third temperature measurement was taken at the end of the 10 minute mixing cycle.

Temperature data for the test mixes are shown in Table 3-1. Temperature increases were generally small: on the order of $2{ }^{\circ} \mathrm{C}$.

Table 3-1. Slurry Temperature Data for Test Mixes.

\begin{tabular}{||c|c|c|c||}
\hline Identifier & $\begin{array}{c}\text { Salt Solution } \\
\text { Temp. }\left({ }^{\circ} \mathbf{C}\right)\end{array}$ & $\begin{array}{c}\text { Slurry Temp. After Dry } \\
\text { Feeds Addition }\left({ }^{\circ} \mathbf{C}\right)\end{array}$ & $\begin{array}{c}\text { Slurry Temp. After } \\
\text { Mixing }\left({ }^{\circ} \mathbf{C}\right)\end{array}$ \\
\hline NWS-01 & 21.5 & 22.4 & 23.8 \\
\hline NWS-02 & 20.9 & 22.0 & 23.6 \\
\hline NWS-03 & 20.8 & 21.5 & 23.4 \\
\hline NWS-04 & 20.9 & 22.2 & 25.0 \\
\hline NWS-05 & 21.3 & 22.5 & 23.6 \\
\hline NWS-06 & 21.0 & 22.3 & 24.0 \\
\hline NWS-07 & 21.0 & 22.0 & 24.4 \\
\hline NWS-08 & 21.9 & 22.9 & 24.8 \\
\hline NWS-09 & 21.2 & 22.3 & 23.8 \\
\hline NWS-10 & 22.2 & 23.2 & 25.3 \\
\hline NWS-11 & 21.2 & 22.4 & 23.9 \\
\hline NWS-12 & 21.3 & 22.8 & 24.1 \\
\hline NWS-13 & 21.1 & 22.2 & 24.3 \\
\hline NWS-14 & 21.5 & 22.9 & 24.8 \\
\hline NWS-15 & 21.2 & 22.4 & 24.6 \\
\hline NWS-16 & 21.8 & 23.1 & 24.8 \\
\hline NWS-17 & 21.8 & 23.0 & 24.8 \\
\hline NWS-18 & 21.3 & 23.0 & 24.9 \\
\hline NWS-19 & 21.4 & 22.8 & 24.6 \\
\hline NWS-20 & 21.5 & 22.8 & 24.5 \\
\hline \hline
\end{tabular}

Replicates

\footnotetext{
${ }^{a}$ The calorimeter used for heat of hydration mixes can support eight simultaneous measurements. Therefore, only the first eight test mixes could be measured after fabrication of the large batches. Smaller batches of the targeted compositions were later fabricated for the remaining heat of hydration measurements using a vibratory mixer (Resodyn $^{\mathrm{TM}}$ Acoustic Mixers, Inc.).
} 


\subsection{Slurry Rheology}

Flow behavior of the fresh Cast Stone slurry will be an important parameter in designing a production facility, and will dictate the way the material is transported and fills a container or tank. Rheological properties of the freshly prepared test mixes were measured with a Haake VT550 rotoviscometer. The VT550 was used to obtain a flow curve (shear stress versus shear rate data) using a concentric geometry, cylindrical bob and cup (model MV2). The MV2 bob was selected given its range of measurement and design (e.g., the only shearing surface is the cylinder itself). Measurements were obtained at the temperature of the slurry (i.e., the temperature as measured at the end of the mixing activities).

The functionality of the VT550 was checked using a National Institute of Standards and Technology (NIST)-traceable N35 Newtonian viscosity oil standard at $25{ }^{\circ} \mathrm{C}$ at the beginning of each day. The VT550 was considered functional if the resulting flow curve, analyzed as a Newtonian fluid, was within $\pm 10 \%$ of the NIST viscosity value.

The flow curve used for the measurements is shown in Table 3-2. This flow curve was developed for the SRS saltstone slurries analyzed by SRNL given gel time issues, hence the short time used in obtaining the flow curve profile. Potential issues are over-estimation of the properties on the up curve and under-estimation of the properties on the down curve if the fluid is very thin, due to the MV2 inertia effects. However, these issues were not observed for these test mixes.

Table 3-2. Flow Curve Profile Using MV2 Geometry.

\begin{tabular}{||c|c|c|c||}
\hline \hline & Up Curve & Hold & Down Curve \\
\hline $\begin{array}{c}\text { Shear Rate and Time } \\
\text { of Measurement }\end{array}$ & $\begin{array}{c}0 \text { to } 300 \mathrm{~s}^{-1} \text { linearly } \\
\text { in } 2 \text { minutes }\end{array}$ & $\begin{array}{c}300 \mathrm{~s}^{-1} \text { for } \\
30 \mathrm{~seconds}\end{array}$ & $\begin{array}{c}300 \text { to } 0 \mathrm{~s}^{-1} \text { linearly } \\
\text { in } 2 \text { minutes }\end{array}$ \\
\hline
\end{tabular}

The data were analyzed using a Bingham Plastic rheological model, providing yield stress and plastic viscosity values. The Haake software converts the rotational rate of the rotating surface of the bob into a shear rate assuming the material being measured is a Newtonian fluid. This shear rate is used when modeling the flow curve as a Bingham Plastic fluid. Both the up and down curves were fitted to the Bingham Plastic rheological model. ${ }^{8}$

Results of the rheology measurements are given in Table 3-3. In general, all of the slurries were very flowable, which should aid in the design of production and disposal facilities. 
SRNL-STI-2013-00499

Revision 0

Table 3-3. Rheological Properties of the Fresh Test Mixes.

\begin{tabular}{|c|c|c|}
\hline Identifier $^{*}$ & Yield Stress (Pa) & Plastic Viscosity (cP) \\
\hline NWS-01 $^{*}$ & 2.34 & 83.4 \\
\hline NWS-02 & 2.91 & 51.8 \\
\hline NWS-03 & 1.68 & 73.1 \\
\hline NWS-04 & 4.05 & 117.1 \\
\hline NWS-05 & 2.31 & 72.1 \\
\hline NWS-06 & 2.77 & 49.5 \\
\hline NWS-07 & 2.48 & 97.2 \\
\hline NWS-08 & 2.50 & 62.7 \\
\hline NWS-09 & 1.86 & 41.0 \\
\hline NWS-10 & 4.00 & 85.3 \\
\hline NWS-11 & 1.96 & 57.5 \\
\hline NWS-12 & 2.54 & 67.4 \\
\hline NWS-13 & 2.42 & 93.5 \\
\hline NWS-14 & 3.27 & 72.9 \\
\hline NWS-15 & 2.50 & 90.2 \\
\hline NWS-16 & 2.57 & 65.7 \\
\hline NWS-17 & 2.07 & 59.5 \\
\hline NWS-18 & 4.87 & 71.8 \\
\hline NWS-19 & 3.03 & 54.8 \\
\hline NWS-20 & 2.41 & 65.5 \\
\hline \hline
\end{tabular}

Replicates

\subsection{Fresh Density}

Density of the fresh Cast Stone slurry is a property of importance in designing a production facility. The densities of the freshly prepared mixes were measured with weight per gallon sample cups (Paul N. Gardner Company, Inc.) using a simplified version of ASTM D 1475, Standard Test Method For Density of Liquid Coatings, Inks, and Related Products. ${ }^{9}$ Prior to testing, the volume of the sample cup with the cap in place was verified with ASTM Type I water at room temperature following the calibration steps in the ASTM D 1475 method. To measure each sample, the container was filled with fresh slurry to form a meniscus. The container was capped and the excess material expressed from the overflow was wiped away. The container was wiped to remove any grout from the outer surfaces and then placed on a balance to obtain the mass of the sample. The fresh density was then calculated from the mass of the sample divided by the known volume of the container.

The measured fresh density values for each test mix are given in Table 3-4. These values are consistent with the fresh densities measured for the Cast Stone screening matrix study performed at SRNL and PNNL. ${ }^{10}$ 
SRNL-STI-2013-00499

Revision 0

Table 3-4. Measured Fresh Density Values for the Test Mixes.

\begin{tabular}{|c|c|}
\hline Identifier & $\begin{array}{c}\text { Fresh Density } \\
(\mathbf{g} / \mathbf{m l})\end{array}$ \\
\hline NWS-01 $^{*}$ & 1.82 \\
\hline NWS-02 & 1.77 \\
\hline NWS-03 & 1.79 \\
\hline NWS-04 & 1.84 \\
\hline NWS-05 $^{*}$ & 1.78 \\
\hline NWS-06 & 1.75 \\
\hline NWS-07 & 1.83 \\
\hline NWS-08 & 1.79 \\
\hline NWS-09 & 1.76 \\
\hline NWS-10 & 1.81 \\
\hline NWS-11 & 1.77 \\
\hline NWS-12 & 1.79 \\
\hline NWS-13 & 1.81 \\
\hline NWS-14 & 1.80 \\
\hline NWS-15 & 1.80 \\
\hline NWS-16 & 1.81 \\
\hline NWS-17 & 1.79 \\
\hline NWS-18 & 1.82 \\
\hline NWS-19 & 1.80 \\
\hline NWS-20 & 1.80 \\
\hline \hline
\end{tabular}

Replicates

\subsection{Standing Water}

The presence of standing water is a preliminary indication that settling may have occurred in the mix and is also of interest for disposal facility design. Settling is of potential concern at the higher water to premix ratios investigated in this study due to the lower viscosity of the mixes. Observations of free liquids or standing water were made for each of the test mixes following the method described by Harbour, et al. ${ }^{11}$

The volume percentage of standing water was determined by measuring the residual liquid remaining atop samples cast into 1 inch diameter by 4 inch cylindrical plastic molds. The measurements were made after about 24 hours from mixing and again after about 72 hours to check for reabsorption. The amount of the liquid was measured as a mass due to the minimal volumes. The density of the liquid was assumed to be the same as that of the simulated salt solution used to prepare the mix in order to convert to a volume basis.

The standing water is reported as the percentage volume of fluid measured relative to the volume of hardened Cast Stone. As shown in Table 3-5, only three of the test mixes exhibited measureable standing water after 24 hours, and in each case the volume of liquid was small. Mix NWS-09 was the only composition with standing water remaining after 72 hours from mixing. Mix NWS-09 was also one of the most fluid slurries, with the lowest measured plastic viscosity and the second lowest yield strength (see Section 3.3). It may be hypothesized that the combination of relatively low salt solution concentration $(7.0 \mathrm{M} \mathrm{Na})$, high water to premix ratio (0.70), and low slag content (25 wt \% of the premix) of mix NWS-09 led to the observation of free liquid remaining after 72 hours. The relatively low volume of standing water would have to be evaluated to determine whether it would be of concern to the design of a Cast Stone disposal 
facility. Settling of the mixes was further investigated via density gradient measurements of cured samples, described later in Section 4.4.

Table 3-5. Standing Water Measurements for Test Mixes that Exhibited Free Liquids.

\begin{tabular}{||c|c|c|c|c||}
\hline \hline Identifier & $\begin{array}{c}\text { Day 1, Replicate 1 } \\
\text { (vol \%) }\end{array}$ & $\begin{array}{c}\text { Day 1, Replicate 2 } \\
\text { (vol \%) }\end{array}$ & $\begin{array}{c}\text { Day 2, Replicate 1 } \\
\text { (vol \%) }\end{array}$ & $\begin{array}{c}\text { Day 2, Replicate 2 } \\
\text { (vol \%) }\end{array}$ \\
\hline NWS-09 & 0.54 & 0.57 & 0.35 & 0.39 \\
\hline NWS-17 & 0.17 & 0.15 & 0 & 0 \\
\hline NWS-19 & 0.18 & 0.21 & 0 & 0 \\
\hline
\end{tabular}

\subsection{Heat of Hydration}

Heat of hydration data were collected for each test mix using a Thermometric TAM Air Isothermal Calorimeter (TA Instruments) at a constant temperature of $25^{\circ} \mathrm{C}$ following ASTM C1679. ${ }^{12}$ Sample size was approximately $18 \mathrm{~g}$. Each sample was run for about 300 hours to capture as much data as practical, since hydration continues almost indefinitely. The calorimeter allows for eight samples to be measured concurrently.

The data collected were reviewed to determine the total heat generated normalized to the amount of dry blend materials in the sample, the time to peak heat flow, and the peak normalized heat flow. The data are shown in Table 3-6. Graphic representations of these data are shown in Figure 3-1 through Figure 3-3. In general, the time to peak heat flow is shorter for the mixes fabricated with the $10.0 \mathrm{M}$ sodium salt solution (Figure 3-1). Other conclusions related to the peak normalized heat flow (Figure 3-2) and the normalized heat (Figure 3-3) are difficult to draw based on the spread of the data. A further review of these data is provided in Section 5.0. 
Table 3-6. Heat of Hydration Data for the Test Mixes.

\begin{tabular}{|c|c|c|c|}
\hline Identifier & $\begin{array}{c}\text { Normalized } \\
\text { Heat }(\mathrm{J} / \mathrm{g})\end{array}$ & $\begin{array}{c}\text { Time to Peak } \\
\text { Heat Flow (hr) }\end{array}$ & $\begin{array}{l}\text { Peak Normalized } \\
\text { Heat Flow }(\mathrm{mW} / \mathrm{g})\end{array}$ \\
\hline NWS-01" & 293 & 66.6 & 2.4 \\
\hline NWS-02 & 338 & 68.6 & 1.5 \\
\hline NWS-03 & 310 & 50.1 & 2.1 \\
\hline NWS-04 & 315 & 38.9 & 3.8 \\
\hline NWS-05" & 304 & 66.2 & 2.6 \\
\hline NWS-06 & 362 & 60.2 & 1.6 \\
\hline NWS-07 & 295 & 46.0 & 2.3 \\
\hline NWS-08* & 305 & 65.2 & 2.7 \\
\hline NWS-09 & 289 & 84.6 & 1.0 \\
\hline NWS-10 & 284 & 69.2 & 1.7 \\
\hline NWS-11 & 285 & 73.3 & 1.4 \\
\hline NWS-12 & 284 & 73.0 & 1.6 \\
\hline NWS-13 & 282 & 45.9 & 2.1 \\
\hline NWS-14 & 299 & 59.3 & 1.9 \\
\hline NWS-15 & 290 & 44.3 & 2.2 \\
\hline NWS-16 & 284 & 72.9 & 1.6 \\
\hline NWS-17 & 267 & 77.5 & 1.4 \\
\hline NWS-18 & 335 & 58.1 & 1.4 \\
\hline NWS-19 & 294 & 75.8 & 1.4 \\
\hline NWS-20 & 283 & 69.1 & 2.0 \\
\hline
\end{tabular}

*Replicates 


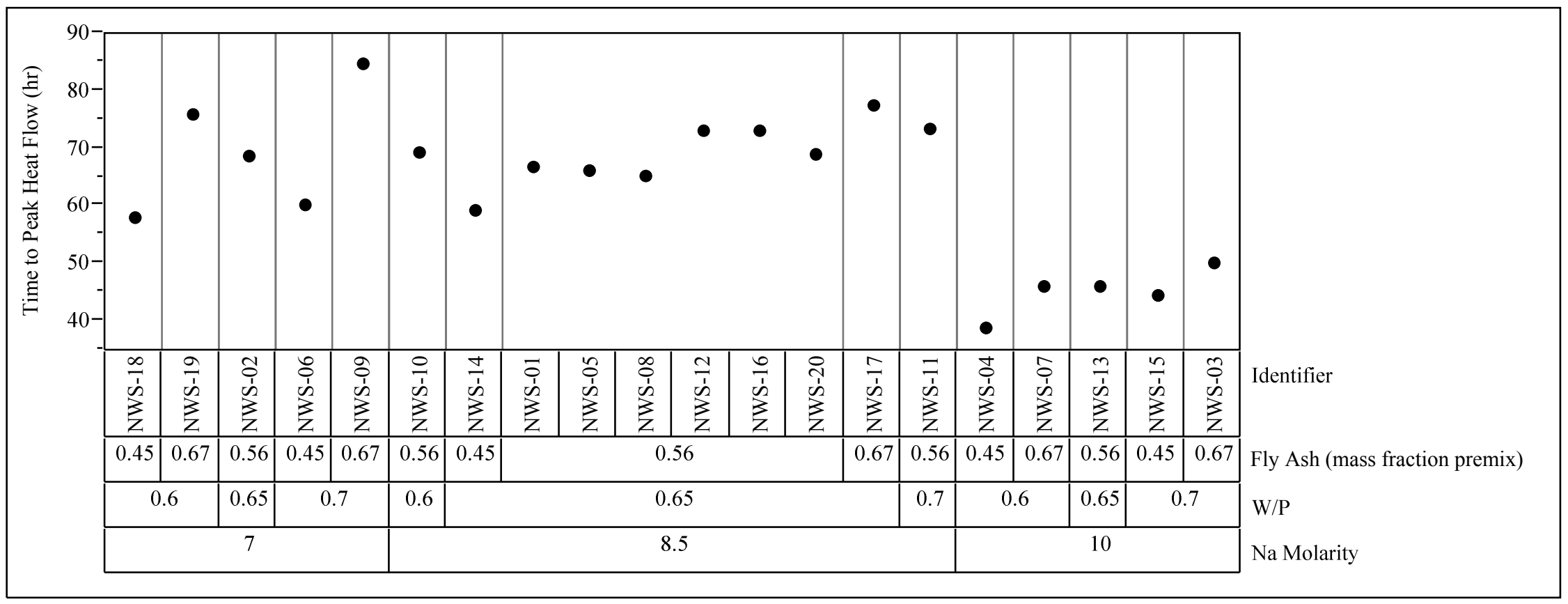

Figure 3-1. Time to Peak Heat Flow as a Function of Mix Composition. 


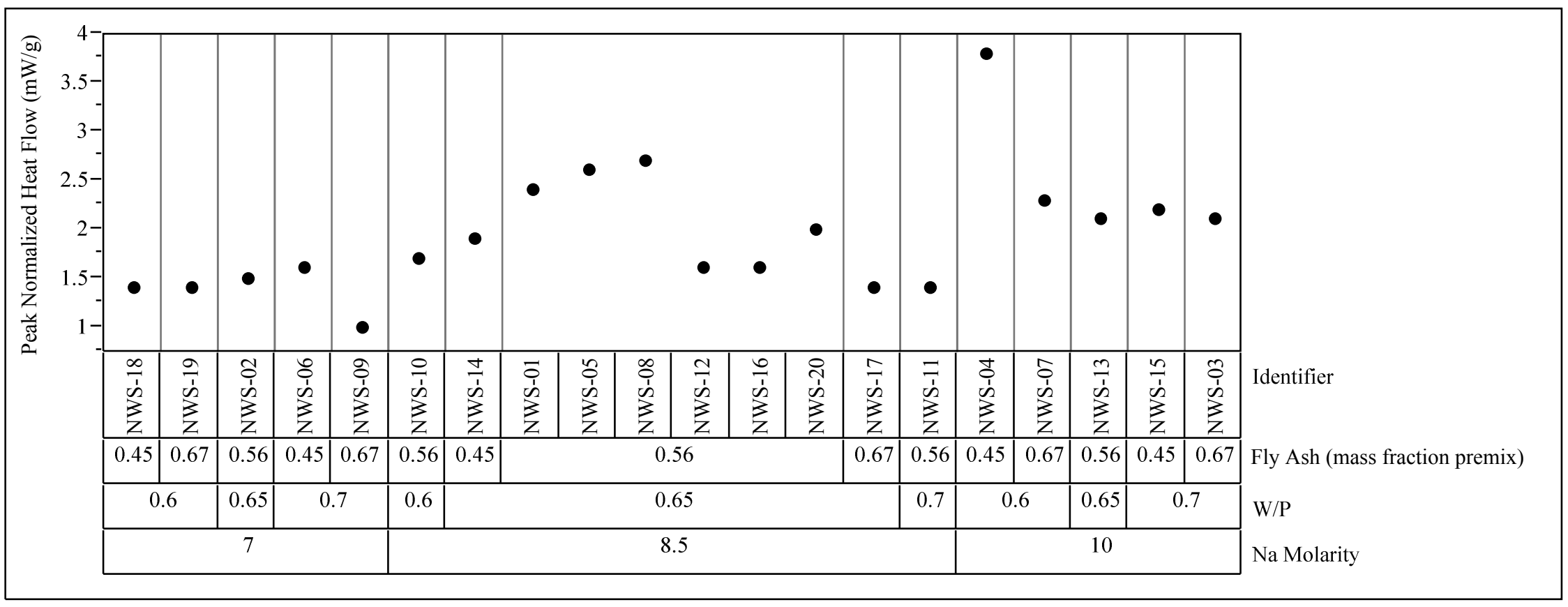

Figure 3-2. Peak Normalized Heat Flow as a Function of Mix Composition. 


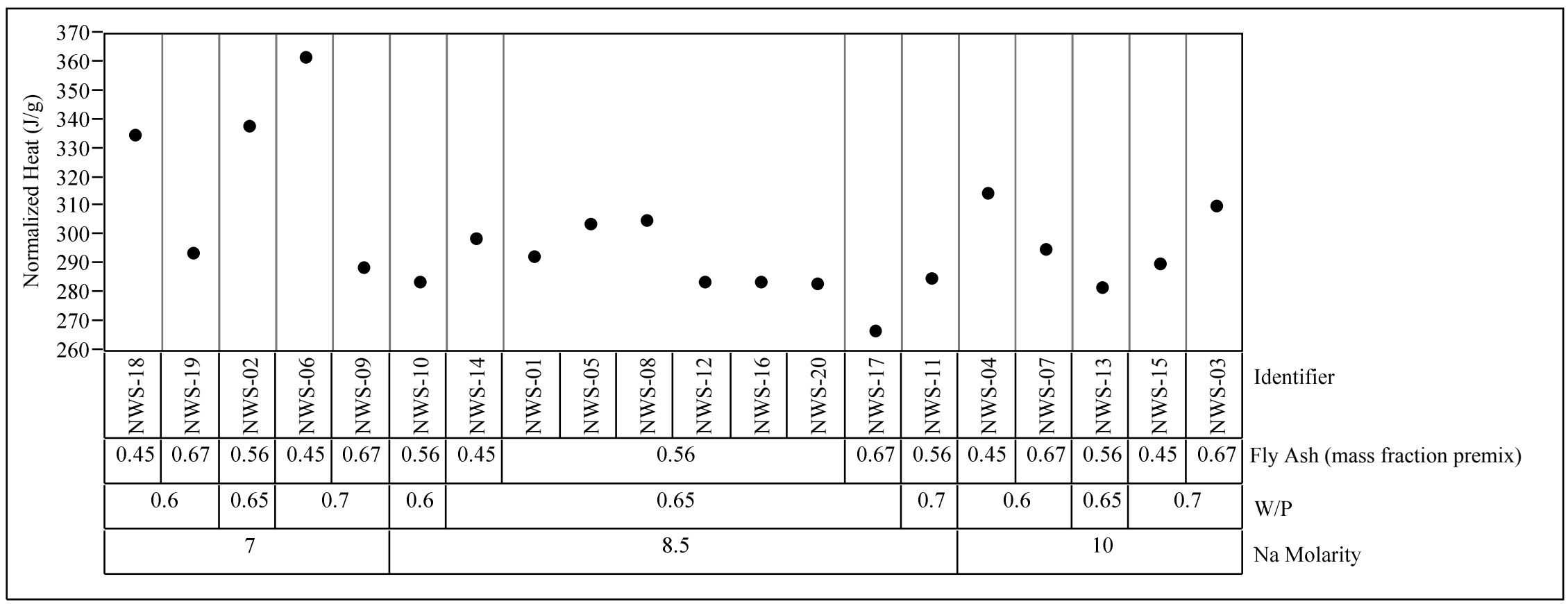

Figure 3-3. Normalized Heat as a Function of Mix Composition. 
SRNL-STI-2013-00499

Revision 0

\subsection{Cured Properties}

\subsection{Chemical Composition}

Samples of each of the test mixes after at least 28 days of curing were chemically digested to determine their elemental compositions. Samples were pulverized using a Wig L Bug grinding mill with agate grinding media. The samples were ground to a fine powder to increase the

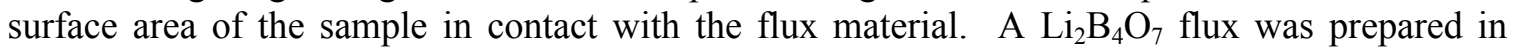
$50 \mathrm{ml}$ platinum crucibles by adding $0.1 \mathrm{~g}$ of sample to the crucible and $0.5 \mathrm{~g}$ of $\mathrm{Li}_{2} \mathrm{~B}_{4} \mathrm{O}_{7}$. The material was mixed and another $0.5 \mathrm{~g}$ of sample was added on top of the mixed material in the crucible. The crucible was then placed in a furnace at $1000^{\circ} \mathrm{C}$ for 30 minutes and taken out to cool. A magnetic stir bar was added to the crucible after cooling and $20 \mathrm{ml}$ of $4 \%$ nitric acid and $2 \mathrm{ml}$ of concentrated $\mathrm{HCl}$ were added to the crucible. The sample was placed on a heated stir plate set at $90^{\circ} \mathrm{C}$. After the sample dissolved, the contents were poured into a $100 \mathrm{ml}$ volumetric flask and brought to volume with deionized water.

To prepare the samples for anion analyses, $1 \mathrm{~g}$ of the pulverized sample was added to a $50 \mathrm{ml}$ platinum crucible. Three grams of $\mathrm{KOH}$ were added to the crucible. The crucible was then placed in a heating block set at $360^{\circ} \mathrm{C}$. The heating block was placed on a gyratory shaker set at $125 \mathrm{rpm}$. The flux was heated and shaken for at least 1 hour or until the sample solidified. The crucible was then removed, allowed to cool, and a magnetic stir bar was added. Ten milliliters of deionized water were added to the crucible and the sample was stirred for about 30 minutes at $90{ }^{\circ} \mathrm{C}$. The sample digestion was then transferred to a $50 \mathrm{ml}$ volumetric flask and brought to volume with deionized water.

The compositions of the prepared solutions were determined using ICP-OES analyses for cations and IC analyses for anions. Chemical composition data for each of the mixes are included in Table A-1 of Appendix A for reference. Note that the total recovery is about 85 to $90 \mathrm{wt} \%$ on an oxide basis. This is likely due to the loss of hydroxide and carbonate during the dissolutions.

\subsection{Compressive Strength}

The uniaxial compressive strength of each text mix was measured in triplicate after 28 and 90 days of curing following ASTM C 39/39M. ${ }^{13}$ Compressive strength is commonly used as an indication of the overall quality (mix design and preparation) of the sample. The LAW waste form for disposal at the Hanford Site is required to have a compressive strength of at least 500 psi. $^{14}$

Triplicate samples of each test mix were cast into two inch diameter by four inch cylindrical plastic molds. After the curing period, the molds were removed with an oscillating saw. The sample mass was measured with a laboratory balance and its dimensions (length and diameter) were measured with calipers. It was then placed into a hydraulic load frame for uniaxial compression testing. Unbonded neoprene pad caps were used on both ends of the specimens to account for the uneven surfaces. ${ }^{15}$ The loading rate was set to approximately $35 \mathrm{psi} / \mathrm{s}$ per the ASTM procedure. The data logging threshold was set to $400 \mathrm{lb}$ and the break threshold was set to $500 \mathrm{lb}$. The maximum load at fracture was recorded. Most of the samples broke in the side fracture manner - identified as Type 5 in ASTM C39/39M - which is noted to be common with the use of unbonded caps.

A compressive strength value was calculated for each specimen, and the mean of the triplicate values for each of the test mixes for each of the curing periods is reported in Table 4-1. After 28 
days of curing, several of the test mixes had mean compressive strengths that were below the 500 psi requirement. Those test mixes with higher mean compressive strengths after 28 days of curing tended to be those made with the 7.0 M Na salt solution.

All of the test mixes exhibited higher mean compressive strengths after 90 days of curing. NWS-03 was the only test mix with a mean compressive strength below 500 psi. Mix NWS-03 had a combination of high sodium molarity $(10.0 \mathrm{M})$, high water to premix ratio $(0.70)$, and low slag content ( $25 \mathrm{wt} \%$ of premix). As will be shown below, this mix also had the highest measured porosity and a gradient in cured density. It is hypothesized that these factors led to the relatively low compressive strength of this mix.

Mix NWS-16 also had a relatively low mean compressive strength. Note however that the standard deviation of the triplicate measurements of this mix was $604 \mathrm{psi}$, which is greater than the mean value. Also note that mix NWS-16 was one of the centroid replicates, the others of which had much higher compressive strength values after 90 days of curing. It is possible that some of the NWS-16 triplicate specimens contained flaws that led to an unusually low mean measurement. These experiments should be repeated before further conclusions are drawn. Complete data for the compressive strength measurements are included in Appendix B.

Table 4-1. 28 and 90-Day Compressive Strength Data.

\begin{tabular}{||c|c|c||}
\hline Identifier & $\begin{array}{c}\text { 28-Day Compressive } \\
\text { Strength (psi) }\end{array}$ & $\begin{array}{c}\text { 90-Day Compressive } \\
\text { Strength (psi) }\end{array}$ \\
\hline NWS-01 & 490 & 1100 \\
\hline NWS-02 & 1350 & 2690 \\
\hline NWS-03 & 170 & 460 \\
\hline NWS-04 & 700 & 1200 \\
\hline NWS-05 & 490 & 1200 \\
\hline NWS-06 & 1430 & 2310 \\
\hline NWS-07 & 270 & 800 \\
\hline NWS-08 & 560 & 1280 \\
\hline NWS-09 & 680 & 2200 \\
\hline NWS-10 & 830 & 1540 \\
\hline NWS-11 & 320 & 1040 \\
\hline NWS-12 & 550 & 1220 \\
\hline NWS-13 & 300 & 810 \\
\hline NWS-14 & 800 & 1350 \\
\hline NWS-15 & 380 & 690 \\
\hline NWS-16 & 480 & 540 \\
\hline NWS-17 & 400 & 1150 \\
\hline NWS-18 & 2200 & 3460 \\
\hline NWS-19 & 1070 & 3220 \\
\hline NWS-20 & 520 & 1230 \\
\hline${ }^{*}$ Replicates & & \\
\hline
\end{tabular}

\subsection{Density and Porosity}

Density and porosity of the cured Cast Stone can be used as inputs to predictions of the performance of the waste form. Densities of the cured samples were measured on pieces of samples tested for 28-day compressive strength. Portions of the failed compressive strength samples were collected from internal pieces of the primary sample to limit the extent of drying. 
Density was measured using a laboratory balance and helium pycnometry (triplicate volume measurements) following the SRNL procedure. ${ }^{16}$ The density data are reported in Table 4-2.

The porosity was also measured on pieces of samples tested for compressive strength. The porosity was measured following the SRNL procedure described elsewhere. ${ }^{16}$ The measurements took place immediately after the compression testing to minimize potential bias imparted by drying. The porosity data are also reported in Table 4-2. These properties will be further related to the compositions of the test mixes in Section 5.0.

Table 4-2. Density and Porosity Data.

\begin{tabular}{|c|c|c|}
\hline Identifier & $\begin{array}{c}\text { Density } \\
\left(\mathbf{g}^{\mathbf{2}} \mathbf{~}^{\mathbf{m}}\right.\end{array}$ & $\begin{array}{c}\text { Porosity } \\
\mathbf{( \% )}\end{array}$ \\
\hline NWS-01 $^{*}$ & 1.78 & 64.3 \\
\hline NWS-02 & 1.77 & 61.3 \\
\hline NWS-03 & 1.80 & 68.3 \\
\hline NWS-04 & 1.83 & 63.7 \\
\hline NWS-05 & 1.77 & 63.1 \\
\hline NWS-06 & 1.75 & 62.1 \\
\hline NWS-07 & 1.81 & 63.8 \\
\hline NWS-08 & 1.78 & 63.9 \\
\hline NWS-09 & 1.73 & 62.9 \\
\hline NWS-10 & 1.82 & 61.8 \\
\hline NWS-11 & 1.77 & 65.3 \\
\hline NWS-12 & 1.79 & 63.2 \\
\hline NWS-13 & 1.81 & 66.0 \\
\hline NWS-14 & 1.81 & 63.6 \\
\hline NWS-15 & 1.79 & 66.9 \\
\hline NWS-16 & 1.78 & 63.3 \\
\hline NWS-17 & 1.77 & 62.2 \\
\hline NWS-18 & 1.80 & 58.0 \\
\hline NWS-19 & 1.78 & 58.3 \\
\hline NWS-20 & 1.79 & 62.4 \\
\hline \hline
\end{tabular}

"Replicates

\subsection{Density Gradient}

As mentioned earlier, settling of the solid particles is of potential concern at the higher water to premix ratios investigated in this study due to the lower viscosity of the slurries. One way to determine whether settling has occurred is to measure the density of cured Cast Stone samples as a function of height. For this method, samples were cast into 1 inch diameter by 4 inch cylindrical plastic molds and cured for at least 28 days. Each mold containing the Cast Stone was then sectioned with a hacksaw into three pieces of approximately equal size representing the top, middle, and bottom of the sample. If settling occurred, the bottom section would be expected to have a higher density than the top section.

The density of each sample was determined as described in Section 4.3 after removing it from the plastic mold. Measurements were made as quickly as possible to minimize bias due to drying. The volume of each section (top, middle, and bottom) was measured three times using a helium pycnometer, with the average of these values used in calculating the density of the section. The individual density values are included in Table C-1 of Appendix C. 
An analysis of variance was conducted for the measurements of each text mix with the detailed results included in Exhibit C-1 of Appendix C. The mean values for the top, middle, and bottom sections of each test mix are tabulated in Table 4-3. Those mixes that are highlighted in Table 4-3 had differences in the means of the measured densities among the top, middle, and bottom sections that were statistically significant at the $95 \%$ confidence level. NWS-03 is the only mix that had a density at the bottom of the sample that was higher than that of the top of the sample with statistical significance. While some of the other mixes exhibited differences that were statistically significant, the magnitude of those differences is quite small, such that it would not be appropriate to draw further conclusions. Mix NWS-03 had a combination of high sodium molarity $(10.0 \mathrm{M})$, high water to premix ratio $(0.70)$, and low slag content ( $25 \mathrm{wt} \%$ of premix), and exhibited the lowest measured yield stress (Section 3.3). It is hypothesized that these factors led to a slurry that was fluid enough to allow for settling to occur. This may have also led to the relatively low compressive strength values for NWS-03 (Section 4.2).

Table 4-3. Density Gradient Data for the Test Mixes.

\begin{tabular}{|c|c|c|c|c|c|}
\hline Identifier & Location & $\begin{array}{c}\text { Density } \\
\text { (g/ml) }\end{array}$ & Identifier & Location & $\begin{array}{c}\text { Density } \\
\text { (g/ml) }\end{array}$ \\
\hline \multirow{3}{*}{ NWS-01* } & Top & 1.72 & \multirow{3}{*}{ NWS-11 } & Top & 1.80 \\
\hline & Middle & 1.75 & & Middle & 1.78 \\
\hline & Bottom & 1.62 & & Bottom & 1.80 \\
\hline \multirow{3}{*}{ NWS-02 } & Top & 1.33 & \multirow{3}{*}{ NWS-12* } & Top & 1.82 \\
\hline & Middle & 1.31 & & Middle & 1.81 \\
\hline & Bottom & 1.33 & & Bottom & 1.82 \\
\hline \multirow{3}{*}{ NWS-03 } & Top & 1.41 & \multirow{3}{*}{ NWS-13 } & Top & 1.84 \\
\hline & Middle & 1.74 & & Middle & 1.90 \\
\hline & Bottom & 1.82 & & Bottom & 1.82 \\
\hline \multirow{3}{*}{ NWS-04 } & Top & 1.76 & \multirow{3}{*}{ NWS-14 } & Top & 1.83 \\
\hline & Middle & 1.80 & & Middle & 1.84 \\
\hline & Bottom & 1.77 & & Bottom & 1.84 \\
\hline \multirow{3}{*}{ NWS- $05^{*}$} & Top & 1.77 & \multirow{3}{*}{ NWS-15 } & Top & 1.82 \\
\hline & Middle & 1.72 & & Middle & 1.83 \\
\hline & Bottom & 1.73 & & Bottom & 1.83 \\
\hline \multirow{3}{*}{ NWS-06 } & Top & 1.72 & \multirow{3}{*}{ NWS-16 } & Top & 1.80 \\
\hline & Middle & 1.72 & & Middle & 1.79 \\
\hline & Bottom & 1.72 & & Bottom & 1.79 \\
\hline \multirow{3}{*}{ NWS-07 } & Top & 1.74 & \multirow{3}{*}{ NWS-17 } & Top & 1.78 \\
\hline & Middle & 1.78 & & Middle & 1.78 \\
\hline & Bottom & 1.76 & & Bottom & 1.80 \\
\hline \multirow{3}{*}{ NWS-08* } & Top & 1.79 & \multirow{3}{*}{ NWS-18 } & Top & 1.82 \\
\hline & Middle & 1.75 & & Middle & 1.82 \\
\hline & Bottom & 1.69 & & Bottom & 1.82 \\
\hline \multirow{3}{*}{ NWS-09 } & Top & 1.75 & \multirow{3}{*}{ NWS-19 } & Top & 1.81 \\
\hline & Middle & 1.77 & & Middle & 1.81 \\
\hline & Bottom & 1.75 & & Bottom & 1.81 \\
\hline \multirow{3}{*}{ NWS-10 } & Top & 1.84 & \multirow{3}{*}{ NWS-20* } & Top & 1.81 \\
\hline & Middle & 1.85 & & Middle & 1.79 \\
\hline & Bottom & 1.85 & & Bottom & 1.81 \\
\hline
\end{tabular}

Replicates 


\subsection{Leach Indices}

The determination of leach indices is a potential method of providing empirical data for use in modeling contaminant release from the waste form to the environment. After curing for approximately 28 days, cylindrical samples of each of the test mixes were removed from their molds and leached following the EPA 1315 procedure. ${ }^{17}$ The testing was performed in duplicate. The leachates were analyzed via ICP-OES for cations, IC for anions, and Gas Chromatography Mass Spectroscopy (GC-MS) for iodine. Initial concentrations of the contaminants in the waste form were determined via the chemical composition measurements of the cured samples described in Section 4.1. The targeted iodine concentrations were used as the initial concentrations of iodine since the preparation for chemical analysis resulted in a significant loss of iodine. Leach indices were determined for several of the components of the waste form, in particular nitrate, nitrite, iodine, chromium, and sodium. The average of the two duplicate leach indices for each contaminant is reported. In cases where the concentration of the contaminant in the leachate was below the method detection limit, that detection limit was used in calculating the leach index, with the leach index reported as being greater than the calculated value. When duplicate analyses both produced a greater than value, the lesser of the two values was reported as an arbitrary measure of conservatism. In no case did the cumulative amount of a contaminant leached from a text mix exceed $20 \%$ of the initial concentration of that contaminant. All of the calculated leach index values are given in Table D-1 of Appendix D for reference.

Select leach indices for the test mixes are reported in Table 4-4. The chromium concentrations in the leachates were below the method detection limit for many of the leaching intervals, resulting in leach indices being reported as greater than values. The leach indices for iodine, sodium, nitrite, and nitrate were generally similar. Any relationship between the values reported in Table 4-4 and the compositions of the test mixes is not readily obvious. These results will be further reviewed in Section 5.0.

Table 4-4. Select Leach Indices (LI) for the Test Mixes.

\begin{tabular}{||c|c|c|c|c|c||}
\hline \hline Identifier & LI (Cr) & LI (I) & LI (Na) & LI (NO $\left.{ }^{-}\right)^{-}$ & LI (NO ${ }_{3}{ }^{-1}$ \\
\hline NWS-01 & $>12.7$ & 9.1 & 9.4 & 9.3 & 9.3 \\
\hline NWS-02 & $>12.5$ & 9.1 & 9.3 & 9.3 & 9.1 \\
\hline NWS-03 & $>12.0$ & 9.5 & 9.2 & 9.3 & 9.0 \\
\hline NWS-04 & $>12.4$ & 9.4 & 9.5 & 9.6 & 9.4 \\
\hline NWS-05 & $>12.6$ & 9.1 & 9.4 & 9.4 & 9.2 \\
\hline NWS-06 & $>12.6$ & 9.2 & 9.4 & 9.3 & 9.2 \\
\hline NWS-07 & $>12.5$ & 8.7 & 9.2 & 8.8 & 8.8 \\
\hline NWS-08 & $>12.6$ & 9.1 & 9.3 & 9.4 & 9.2 \\
\hline NWS-09 & $>12.7$ & 8.8 & 9.3 & 9.0 & 9.0 \\
\hline NWS-10 & $>12.8$ & 9.3 & 9.5 & 9.6 & 9.3 \\
\hline NWS-11 & $>12.7$ & 9.1 & 9.4 & 9.4 & 9.2 \\
\hline NWS-12 & $>12.6$ & 9.3 & 9.5 & 9.6 & 9.4 \\
\hline NWS-13 & $>12.8$ & 9.0 & 9.4 & 9.2 & 9.2 \\
\hline NWS-14 & $>12.6$ & 9.4 & 9.5 & 9.6 & 9.5 \\
\hline NWS-15 & $>12.8$ & 9.3 & 9.6 & 9.6 & 9.5 \\
\hline NWS-16 & $>12.7$ & 9.2 & 9.6 & 9.4 & 9.5 \\
\hline NWS-17 & $>12.5$ & 8.9 & 9.1 & 9.0 & 9.0 \\
\hline NWS-18 & $>12.5$ & 9.4 & 9.4 & 9.5 & 9.3 \\
\hline NWS-19 & $>12.7$ & 8.8 & 9.4 & 9.1 & 9.0 \\
\hline NWS-20 & $>12.6$ & 9.2 & 9.5 & 9.4 & 9.4 \\
\hline \hline
\end{tabular}

"Replicates 


\subsection{Discussion}

JMP Version $9.0 .0^{18}$ was used to conduct the statistical analyses of the data collected in this study, following the design of experiments outlined in Section 2.0. As indicated by Figure 5-1, the Stepwise routine within JMP's Fit Model Platform was utilized to investigate for significant effects among the terms in a candidate response surface model consisting of linear terms, quadratic terms, and terms representing possible pair-wise interactions in the three factors under study: sodium molarity (labeled "Na Molarity"), premix composition, ${ }^{\text {a }}$ and water to premix ratio (labeled "W/P"). The discussion that follows will be limited to the linear terms of the model fits in an attempt to relate the results most directly to the compositions of the test mixes. Data for the more complex model terms are included in the exhibits of Appendix E.

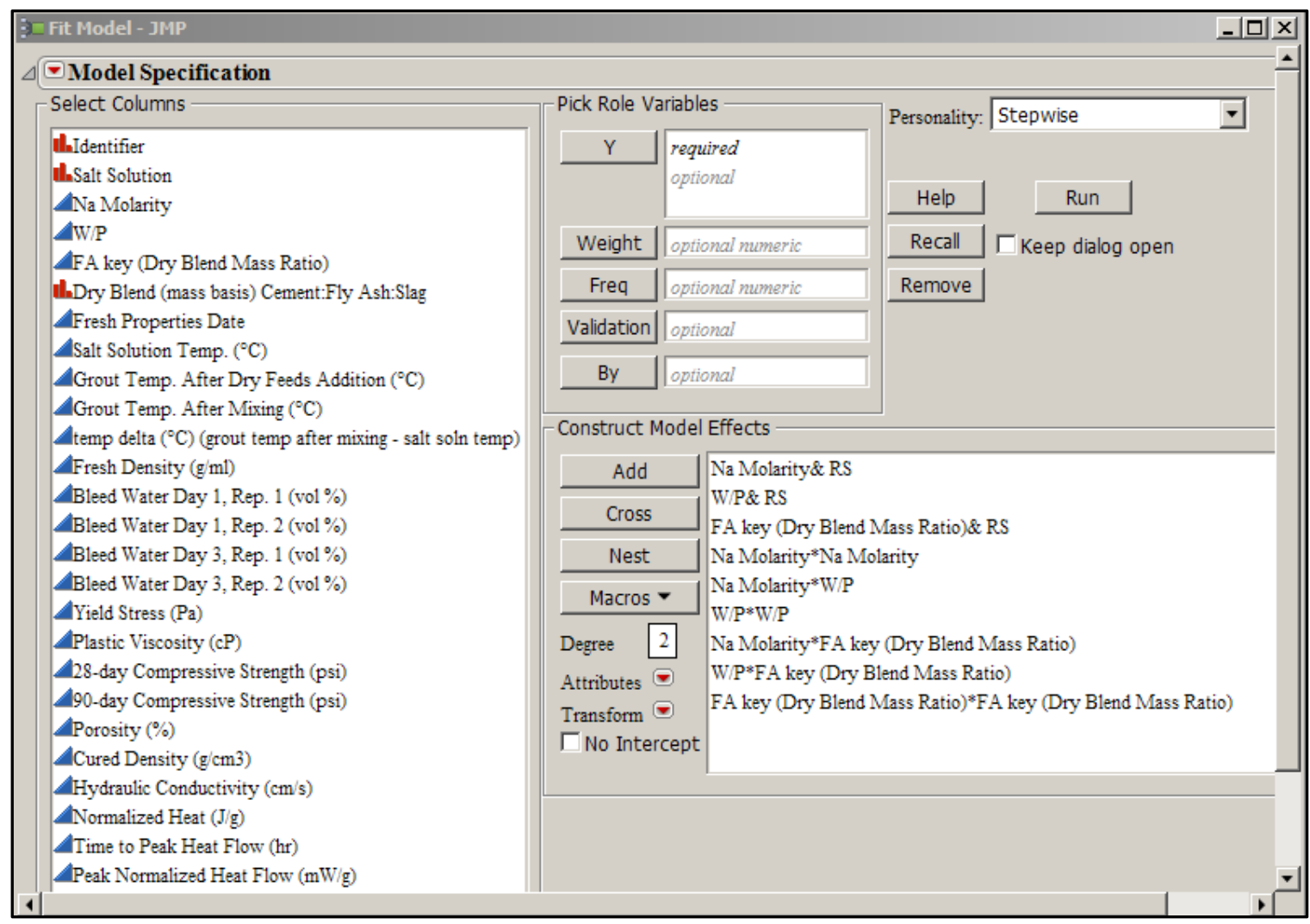

Figure 5-1. Illustration of the Use of JMP's Fit Model Platform

The difference in temperature between the salt solution at the start of the mixing and after about 10 minutes of mixing was measured for each test mix. An increase in temperature of the slurry during mixing may indicate early hydration reactions, and can potentially be linked to other properties of the waste form. The results of the least squares regression analysis of the temperature changes are given in Exhibit E-1 in Appendix E. An increase in water to premix ratio is shown to result in a smaller temperature rise during mixing. Increasing sodium molarity and increasing slag concentrations also led to an increase in temperature rise, although these effects were relatively weak. In general, the temperature rises for the test mixes were on the

\footnotetext{
a The premix composition factor was labeled as "FA key (Dry Blend Mass Ratio)" for the JMP analyses. The values
} used for this factor are the mass fraction of Fly Ash in the premix. 
order of $2{ }^{\circ} \mathrm{C}$, making it difficult to draw any strong conclusions about the influence of mix composition on temperature rise for these experiments.

The results of the least squares regression analyses for the rheology measurements are shown in Exhibit E-2 (yield stress) and Exhibit E-3 (plastic viscosity) in Appendix E. The analysis of the yield stress data shows that increasing the water to premix ratio decreased the yield stress. Increasing the concentration of slag in the premix increased the yield stress. The model showed that increasing sodium molarity increased yield stress, although this was a weaker effect. The analysis of the plastic viscosity data shows that increasing water to premix ratio decreased the plastic viscosity. Increasing sodium molarity increased the plastic viscosity. Increasing the concentration of slag in the premix increased the plastic viscosity, although this was a weaker effect. In general, all of the slurries were very fluid. These data are of potential value in designing a Cast Stone production facility.

Exhibit E-4 in Appendix E shows the results of the least squares regression analysis of the fresh density data. Fresh density is shown to increase with increasing sodium molarity, which is expected since higher sodium concentrations increase the density of the salt solution. Fresh density is also shown to decrease with increasing water to premix ratio, which is expected since the density of the premix materials is higher than that of the salt solution. Note that there is a spread of fresh density values for the six replicates in the study, which has some impact on the ability of the model to fit the study data. Exhibit E-5 in Appendix E shows the results of the least squares regression analysis for the cured density data. Similar to the results for the fresh density data, higher sodium molarity and lower water to premix ratios are shown to lead to higher cured density values. This information is of potential use for the design of a Cast Stone processing facility.

The least squares regression analysis for the porosity data is summarized in Exhibit E-6 of Appendix E. Increasing the water to premix ratio and increasing sodium molarity are shown to increase porosity. The increased water to premix ratio likely leads to a higher volume of pore water, resulting in the higher porosity measurements. The reasoning behind the sodium molarity effect on porosity is not clear from these experiments. The porosity of the waste form can potentially impact its hydraulic properties and other performance criteria.

Heat of hydration measurements may provide some insight into the reactions that occur within the test mixes, which may in turn be related to the properties and performance of the waste form. Exhibit E-7 in Appendix E summarizes the least squares regression analysis for the time to peak heat flow data. The analysis shows that increased sodium concentration in the salt solution reduced the time to peak heat flow. Reducing the amount of slag in the premix increased the time to peak heat flow. Higher water to premix ratios also increased the time to peak heat flow, although this was a weaker relationship. These observations may help to describe some of the cured properties of the samples, such as compressive strength as described below. Exhibit E-8 in Appendix E summarizes the least squares regression analysis for the peak normalized heat flow data. The model fit was poor due to scatter in the data, thus conclusions regarding the normalized heat flow data cannot be drawn. Exhibit E-9 in Appendix E summarizes the least squares regression analysis for the normalized heat data. The model fit was not particularly good ( $\mathrm{R}$ squared value of 0.79), although the results indicate a weak relation to the composition of the premix. Higher slag concentrations appeared to increase the normalized heat. This may indicate that more energy is released due to hydration reactions involving slag as opposed to those involving fly ash. 
The LAW waste form for disposal at the Hanford Site is required to have a compressive strength of at least $500 \mathrm{psi}^{14}$ The results of the least squares regression analyses for the compressive strength measurements are shown in Exhibit E-10 (after 28 days of curing) and Exhibit E-11 (after 90 days of curing) in Appendix E. After 28 days of curing, the analysis shows that higher sodium concentrations and higher water to premix ratios led to reduced compressive strength. This may be due to the larger amounts of porosity in these mixes, as described above. Higher fly ash concentrations decreased the compressive strength after 28 days of curing. This may be explained in that the cementitious phases matured more quickly in the mixes with higher concentrations of slag, as evidenced by the data for the time to peak heat generation, also described above. After 90 days of curing, the analysis shows that higher sodium concentrations and higher water to premix ratios again led to reduced compressive strength. Interestingly, the premix composition did not have a significant effect on compressive strength after 90 days of curing. It is possible that further curing over this extended time period negated any influence of the premix composition.

Three contaminants were selected for the least squares regression analysis of the leaching data: nitrate, iodine, and sodium. The results for the nitrate leach indices are shown in Exhibit E-12 of Appendix E. There is a potential relationship between nitrate and premix composition, in that a higher concentration of fly ash led to a lower LI for nitrate, although there was scatter among the replicates. This may be related to faster maturation of the cementitious phases in the samples containing more slag, as described in the previous paragraphs. The models were poor fits for both the iodine and sodium leaching data, indicating that the results for these contaminants were fairly consistent, regardless of the mix composition. These results show that the leaching performance of the mixes evaluated in this study was not particularly sensitive to the factors used in this experimental design. This may be beneficial in demonstrating that the performance of the waste form is robust with respect to changes in the mix composition. Iodine was above the detection limit for all of the leachates. This indicates that lower, more realistic iodine concentrations could be used for future testing. 


\subsection{Summary and Conclusions}

Formulation of Cast Stone at high sodium concentrations is of interest since a significant reduction in the necessary volume of Cast Stone and subsequent disposal costs could be achieved if an acceptable waste form can be produced with a high sodium molarity salt solution combined with a high water to premix ratio.

The objectives of this study were to evaluate the factors involved with increasing the sodium concentration in Cast Stone, including production and performance properties and the retention and release of specific components of interest.

Three factors were identified for the experimental matrix: the concentration of sodium in the simulated salt solution was varied between 7 and $10 \mathrm{M}$, the water to premix (or dry blend) ratio was varied from 0.6 to 0.7 , and the blast furnace slag portion of the premix was varied from the Cast Stone baseline of $47 \mathrm{wt} \%$ to a reduced level of $25 \mathrm{wt} \%$.

Removal of technetium from the waste stream prior to immobilization is being considered in conjunction with supplemental LAW technologies to enhance the baseline WTP flowsheet; ${ }^{1}$ therefore, a waste form with less reducing capacity (less slag) may be both acceptable and less expensive. Additional fly ash was used when the amount of slag in the premix was reduced, and the amount of cement was held constant. A central composite experimental design was developed utilizing the three factors each at three values, and including six replicates of the centroid test mix to allow for an analysis of the reproducibility of the fabrication and characterization methods used in the study.

The salt solution simulants used in this study were derived from HTWOS to represent the overall average composition.

Chromium and iodine concentrations in the salt solution simulants were adjusted to support leaching experiments. The cement, blast furnace slag, and fly ash used in this study were sourced from a supplier in the Hanford area in order to be representative.

The test mixes were prepared in the laboratory and fresh properties were measured.

Fresh density increased with increasing sodium molarity and with decreasing water to premix ratio, as expected given the individual densities of these components. Rheology measurements showed that all of the test mixes produced very fluid slurries. The fresh density and rheology data are of potential value in designing a future Cast Stone production facility.

Settling was not of particular concern for the high sodium compositions studied.

The presence of standing water is a preliminary indication that settling may have occurred in the mix and is also of interest for disposal facility design. Settling is of potential concern at the higher water to premix ratios investigated in this study due to the lower viscosity of the mixes. Only one of the twenty test mixes (mix NWS-09) exhibited standing water after 72 hours, and the amount of liquid was small. Settling of the mixes was further investigated via density gradient measurements of the cured samples. These measurements identified only one test mix where some settling appeared to have occurred (mix NWS-03), which corresponded to the lowest measured yield stress of the fresh slurries.

Calorimetry indicated that more energy is released due to hydration reactions involving slag than fly ash.

Heat of hydration measurements may provide some insight into the reactions that occur within the test mixes, which may in turn be related to the properties and performance of 
the waste form. These measurements showed that increased sodium concentration in the salt solution reduced the time to peak heat flow, and increasing the amount of fly ash in the premix increased the time to peak heat flow. These observations may help to describe some of the cured properties of the samples, in particular the differences in compressive strength observed after 28 and 90 days of curing. Higher fly ash concentrations appeared to decrease the normalized heat.

Samples were cured for at least 28 days at ambient temperature in the laboratory prior to cured properties analyses.

Cured density measurements were similar to the results for fresh density in that higher sodium molarity and lower water to premix ratios led to higher cured density values. Porosity measurements of the cured samples showed that increasing the water to premix ratio and increasing sodium molarity increased porosity. The increased water to premix ratio likely leads to a higher volume of pore water, resulting in the higher porosity measurements. The reasoning behind the sodium molarity effect on porosity is not clear from these experiments. The porosity of the waste form can potentially impact its hydraulic properties and other performance criteria.

After 28 days of curing, several of the test mixes had mean compressive strengths that were below the 500 psi requirement.

The LAW waste form for disposal at the Hanford Site is required to have a compressive strength of at least $500 \mathrm{psi}^{14}$ Those test mixes with higher mean compressive strengths after 28 days of curing tended to be those made with the $7.0 \mathrm{M}$ Na salt solution. Higher sodium concentrations and higher water to premix ratios led to reduced compressive strength. This may be due to the larger amounts of porosity in these mixes. Lower fly ash concentrations increased the compressive strength after 28 days of curing. This may be explained in that the cementitious phases matured more quickly in the mixes with higher concentrations of slag, as evidenced by the data for the time to peak heat generation.

All of the test mixes exhibited higher mean compressive strengths after 90 days of curing, with only one composition having a mean compressive strength of less than 500 psi.

Mix NWS-03 had a combination of high sodium molarity $(10.0 \mathrm{M})$, high water to premix ratio $(0.70)$, and low slag content ( $25 \mathrm{wt} \%$ of premix), and also had the highest measured porosity and a gradient in cured density. It is hypothesized that these factors led to the relatively low compressive strength of this mix. In general, higher sodium concentrations and higher water to premix ratios again led to reduced compressive strength after 90 days of curing.

The measured leach indices for the various contaminants were fairly consistent among the twenty mixes, indicating that the leaching performance of the mixes evaluated in this study was not particularly sensitive to the factors used in the experimental design. This may be beneficial in demonstrating that the performance of the waste form is robust with respect to changes in the mix composition.

EPA Method 1315 was used to determine leach indices for the test mixes for contaminants of interest. A potential relationship between nitrate and premix composition was identified, in that a higher concentration of slag led to a higher LI for nitrate, although there was a lot of scatter among the replicates. This may be related to faster maturation of the cementitious phases in the samples containing more slag. 


\subsection{Recommendations and Future Work}

The results of this study demonstrate the potential to achieve significantly higher waste loadings in Cast Stone and other low temperature, cementitious waste forms.

Fresh property measurements, such as density and rheology, indicated no issues with respect to processing high sodium concentration Cast Stone through a future production facility. Standing water and settling occurred only at the highest waste loading mixes, which while potentially of concern of disposal facility design, were not seen to significantly impact leaching performance. Compressive strength appears to have the greatest potential to limit sodium concentration in Cast Stone. However, after 90 days of curing only one of the test mixes in this study failed to meet the 500 psi criterion.

Additional work is needed to elucidate the hydration mechanisms occurring in Cast Stone formulated with highly concentrated salt solutions and varying premix compositions, since these reactions are responsible for determining the performance of the cured waste form.

- The thermal analyses completed in this study provide some preliminary insight, although the limited range of the factors in the test matrix hindered the identification of individual component effects. Future work should involve test matrices with broader factor ranges geared toward the identification of the roles played by each of the components in the mix via thermal analyses, analytical microscopy, and characterization of phase formation.

- Salt solution concentrations beyond $10 \mathrm{M}$ sodium should be evaluated since formulation of Cast Stone at this concentration appears to be feasible, although water to premix ratio may become a performance limiting factor.

- Hydraulic properties of high sodium formulations are needed to support performance modeling efforts.

- Leaching experiments with lower, more realistic iodine concentrations in Cast Stone should be performed.

- A study of the performance of high sodium Cast Stone containing technetium would also be valuable, should technetium removal efforts not be implemented as well as for secondary waste immobilization. 
SRNL-STI-2013-00499

Revision 0

\subsection{References}

1. Wilmarth, W. R., D. J. McCabe, C. A. Nash, A. D. Cozzi, C. F. Brown, J. J. H. Westsik, R. J. Serne, and B. M. Rapko, "Preliminary Assessment of the Low-Temperature Waste Form Technology Coupled with Technetium Removal," U.S. Department of Energy Report SRNL-STI2013-00002/PNNL-22103, Savannah River National Laboratory, Aiken, SC (2013).

2. Westsik, J. H., Jr., "Supplemental Immobilization of Hanford Low Activity Waste: Project Test Plan," U.S. Department of Energy Report TP-62745-001 (DRAFT), Pacific Northwest National Laboratory, Richland, WA (2012).

3. Cozzi, A. D., "Task Technical and Quality Assurance Plan for Hanford Low Activity Waste Cast Stone Screening Test Matrix," U.S. Department of Energy Report SRNL-RP-2012-00816, Rev. 0, Savannah River National Laboratory, Aiken, SC (2012).

4. Langton, C. A., "Properties and Mix Design for Saltstone Slag Formulations," U.S. Department of Energy Report DPST-87-392, Savannah River Laboratory, Aiken, SC (1987).

5. Stone, I. Z., Jr., "Flowsheet Bases, Assumptions, and Requirements," U.S. Department of Energy Report 24590-WTP-RPT-PT-02-005, Rev. 6, Bechtel National, Inc., Richland, WA (2011).

6. Fox, K. M. and A. D. Cozzi, "Task Technical and Quality Assurance Plan for Cast Stone Formulation at Higher Sodium Concentrations," U.S. Department of Energy Report SRNL-RP2013-00111, Revision 0, Savannah River National Laboratory, Aiken, SC (2013).

7. Russell, R. L., J. H. Westsik, Jr., D. J. Swanberg, R. E. Eibling, A. D. Cozzi, M. J. Lindberg, G. B. Josephson, and D. E. Rinehart, "Letter Report: LAW Simulant Development for Cast Stone Screening Tests," U.S. Department of Energy Report PNNL-22352, Pacific Northwest National Laboratory, Richland, WA (2013).

8. Darby, R., Chemical Engineering Fluid Mechanics, Second Edition, Marcel Dekker, Inc., New York (2001).

9. ASTM, "Standard Test Method For Density of Liquid Coatings, Inks, and Related Products," ASTM D-1475, (2012).

10. Westsik, J. H., Jr., G. F. Piepel, M. J. Lindberg, P. G. Heasler, T. M. Mercier, R. L. Russell, A. D. Cozzi, W. E. Daniel, R. E. Eibling, E. K. Hansen, and M. M. Reigel, "Supplemental Immobilization of Hanford Low-Activity Waste: Cast Stone Screening Tests," U.S. Department of Energy Report SRNL-STI-2013-00465, Revision 0, Pacific Northwest National Laboratory, Richland, WA (2013).

11. Harbour, J. R., T. B. Edwards, E. K. Hansen, and V. J. Williams, "Variability Study for Saltstone," U.S. Department of Energy Report WSRC-TR-2005-00447, Rev. 0, Savannah River National Laboratory, Aiken, SC (2005).

12. ASTM, "Standard Practice for Measuring Hydration Kinetics of Hydraulic Cementitious Mixtures Using Isothermal Calorimetry," ASTM C-1679, (2009). 
13. ASTM, "Standard Test Method for Compressive Strength of Cylindrical Concrete Specimens," ASTM C39/39M, (2010).

14. U.S. Nuclear Regulatory Commission, "Technical Position on Waste Form (Revision 1)," Office of Nuclear Material Safety and Safeguards, Washington, D.C. (1991).

15. ASTM, "Standard Practice for Use of Unbonded Caps in Determination of Compressive Strength of Hardened Concrete Cylinders," ASTM C1231 / C1231M, (2012).

16. Harbour, J. R., V. J. Williams, T. B. Edwards, R. E. Eibling, and R. F. Schumacher, "Saltstone Variability Study - Measurement of Porosity," U.S. Department of Energy Report WSRC-STI-2007-00352, Rev. 0, Savannah River National Laboratory, Aiken, SC (2007).

17. U.S. Environmental Protection Agency, "Mass Transfer Rates of Constituents in Monolithic or Compacted Granular Materials Using a Semi-dynamic Tank Leaching Procedure," EPA 1315, (2013).

18. JMP®, Ver. 9.0.0, [Computer Software] SAS Institute Inc., Cary, NC (2010). 
SRNL-STI-2013-00499

Revision 0

Appendix A. Chemical Composition Data for the Cured Test Mixes 
Table A-1. Chemical Compositions of the Cured Test Mixes (wt \%).

\begin{tabular}{|c|c|c|c|c|c|c|c|c|c|c|}
\hline & " NWS-01 & " NWS-02 & " NWS-03 & " NWS-04 & " NWS-05 & " NWS-06 & " NWS-07 & " NWS-08 & " NWS-09 & " NWS-10 \\
\hline $\mathrm{Al}_{2} \mathbf{O}_{3}$ & 10.12 & 10.30 & 9.99 & 9.42 & 9.91 & 9.82 & 9.85 & 9.73 & 10.28 & 9.99 \\
\hline $\mathrm{BaO}$ & 0.21 & 0.25 & 0.23 & 0.17 & 0.21 & 0.21 & 0.23 & 0.20 & 0.31 & 0.24 \\
\hline $\mathrm{CaO}$ & 16.70 & 17.85 & 13.79 & 18.07 & 16.56 & 18.68 & 13.94 & 16.33 & 14.98 & 16.92 \\
\hline $\mathrm{Cr}_{2} \mathrm{O}_{3}$ & 0.12 & 0.11 & 0.15 & 0.13 & 0.12 & 0.12 & 0.13 & 0.12 & 0.13 & 0.15 \\
\hline $\mathrm{CuO}$ & 0.05 & 0.04 & 0.03 & 0.03 & 0.02 & 0.02 & 0.06 & 0.01 & 0.02 & 0.07 \\
\hline $\mathrm{Fe}_{2} \mathrm{O}_{3}$ & 2.59 & 2.60 & 2.65 & 2.08 & 2.56 & 2.23 & 2.62 & 2.40 & 3.05 & 2.59 \\
\hline $\mathrm{K}_{2} \mathrm{O}$ & 1.08 & 1.06 & 1.14 & 0.98 & 1.06 & 1.00 & 1.20 & 1.04 & 1.21 & 1.07 \\
\hline MgO & 1.94 & 2.34 & 1.87 & 1.89 & 1.98 & 2.33 & 1.92 & 1.94 & 2.62 & 2.27 \\
\hline $\mathrm{MnO}$ & 0.07 & 0.09 & 0.06 & 0.09 & 0.07 & 0.10 & 0.06 & 0.07 & 0.08 & 0.09 \\
\hline $\mathrm{Na}_{2} \mathrm{O}$ & 15.35 & 12.99 & 18.79 & 16.83 & 15.36 & 13.08 & 17.16 & 14.63 & 13.87 & 14.56 \\
\hline $\mathbf{P}_{2} \mathbf{O}_{5}$ & 0.33 & 0.37 & 0.45 & 0.39 & 0.33 & 0.40 & 0.44 & 0.27 & 0.55 & 0.49 \\
\hline $\mathrm{SO}_{3}$ & 1.61 & 2.17 & 1.63 & 1.99 & 1.93 & 2.44 & 1.56 & 1.76 & 2.13 & 1.90 \\
\hline $\mathrm{SiO}_{2}$ & 28.00 & 29.86 & 27.10 & 25.55 & 28.08 & 26.80 & 27.69 & 27.47 & 30.71 & 28.88 \\
\hline SrO & 0.14 & 0.15 & 0.15 & 0.12 & 0.14 & 0.13 & 0.16 & 0.14 & 0.16 & 0.14 \\
\hline $\mathrm{TiO}_{2}$ & 0.40 & 0.46 & 0.41 & 0.36 & 0.41 & 0.42 & 0.43 & 0.41 & 0.51 & 0.45 \\
\hline $\mathrm{ZnO}$ & 0.01 & 0.02 & 0.01 & 0.01 & 0.01 & 0.02 & 0.02 & 0.01 & 0.02 & 0.02 \\
\hline $\mathrm{ZrO}_{2}$ & 0.02 & 0.02 & 0.02 & 0.03 & 0.02 & 0.03 & 0.02 & 0.02 & 0.02 & 0.02 \\
\hline $\mathrm{Cl}^{-}$ & 0.14 & 0.13 & 0.18 & 0.17 & 0.15 & 0.14 & 0.16 & 0.15 & 0.13 & 0.14 \\
\hline $\mathrm{NO}_{2}^{-}$ & 2.93 & 2.69 & 3.65 & 3.50 & 2.99 & 2.72 & 3.33 & 3.02 & 2.39 & 3.04 \\
\hline $\mathrm{NO}_{3}^{-}$ & 8.02 & 6.13 & 9.97 & 8.49 & 7.63 & 6.67 & 8.95 & 7.82 & 7.09 & 7.21 \\
\hline Total & 89.86 & 89.61 & 92.28 & 90.29 & 89.54 & 87.35 & 89.91 & 87.55 & 90.27 & 90.25 \\
\hline
\end{tabular}


Table A-1. Chemical Compositions of the Cured Test Mixes (wt \%). (continued)

\begin{tabular}{|c|c|c|c|c|c|c|c|c|c|c|}
\hline & "NWS-11 & "NWS-12 & "NWS-13 & "NWS-14 & "NWS-15 & "NWS-16 & "NWS-17 & "NWS-18 & "NWS-19 & "NWS-20 \\
\hline $\mathbf{A l}_{2} \mathbf{O}_{3}$ & 9.65 & 9.74 & 9.48 & 9.50 & 8.98 & 9.82 & 9.93 & 10.56 & 9.75 & 9.61 \\
\hline $\mathrm{BaO}$ & 0.20 & 0.21 & 0.20 & 0.17 & 0.15 & 0.25 & 0.18 & 0.29 & 0.20 & 0.20 \\
\hline $\mathrm{CaO}$ & 15.73 & 16.43 & 15.44 & 18.36 & 16.21 & 14.14 & 20.00 & 15.79 & 16.37 & 16.26 \\
\hline $\mathrm{Cr}_{2} \mathrm{O}_{3}$ & 0.12 & 0.12 & 0.15 & 0.12 & 0.14 & 0.12 & 0.10 & 0.11 & 0.13 & 0.12 \\
\hline $\mathrm{CuO}$ & 0.03 & 0.05 & 0.03 & 0.04 & 0.03 & 0.03 & 0.06 & 0.03 & 0.02 & 0.02 \\
\hline $\mathrm{Fe}_{2} \mathrm{O}_{3}$ & 2.54 & 2.45 & 2.31 & 2.09 & 1.96 & 2.70 & 2.25 & 3.16 & 2.43 & 2.37 \\
\hline $\mathrm{K}_{2} \mathrm{O}$ & 1.01 & 1.06 & 1.03 & 0.98 & 0.94 & 1.17 & 1.00 & 1.23 & 1.06 & 1.06 \\
\hline MgO & 1.90 & 2.00 & 1.88 & 1.93 & 1.76 & 1.98 & 2.07 & 2.39 & 1.94 & 1.92 \\
\hline MnO & 0.07 & 0.07 & 0.07 & 0.08 & 0.07 & 0.06 & 0.09 & 0.08 & 0.07 & 0.07 \\
\hline $\mathrm{Na}_{2} \mathrm{O}$ & 15.43 & 15.09 & 17.98 & 15.32 & 17.96 & 15.63 & 11.84 & 12.47 & 14.95 & 14.97 \\
\hline $\mathbf{P}_{2} \mathbf{O}_{5}$ & 0.41 & 0.40 & 0.45 & 0.40 & 0.44 & 0.42 & 0.30 & 0.41 & 0.40 & 0.39 \\
\hline $\mathrm{SO}_{3}$ & 1.58 & 1.50 & 1.67 & 1.78 & 1.79 & 1.42 & 1.49 & 1.58 & 1.41 & 1.51 \\
\hline $\mathrm{SiO}_{2}$ & 27.58 & 27.41 & 26.12 & 26.48 & 23.15 & 28.36 & 28.52 & 32.05 & 28.07 & 27.58 \\
\hline SrO & 0.14 & 0.14 & 0.13 & 0.12 & 0.11 & 0.16 & 0.13 & 0.17 & 0.14 & 0.14 \\
\hline $\mathrm{TiO}_{2}$ & 0.45 & 0.42 & 0.39 & 0.37 & 0.35 & 0.44 & 0.40 & 0.50 & 0.39 & 0.40 \\
\hline $\mathrm{ZnO}$ & 0.01 & 0.02 & 0.01 & 0.01 & 0.01 & 0.01 & 0.02 & 0.02 & 0.01 & 0.01 \\
\hline $\mathrm{ZrO}_{2}$ & 0.02 & 0.02 & 0.02 & 0.03 & 0.02 & 0.02 & 0.02 & 0.02 & 0.03 & 0.02 \\
\hline $\mathrm{Cl}^{-}$ & 0.16 & 0.15 & 0.17 & 0.15 & 0.18 & 0.15 & 0.15 & 0.13 & 0.12 & 0.16 \\
\hline $\mathrm{NO}_{2}^{-}$ & 3.23 & 3.18 & 3.54 & 2.82 & 3.74 & 2.66 & 3.00 & 2.33 & 2.29 & 3.03 \\
\hline $\mathrm{NO}_{3}^{-}$ & 8.12 & 7.70 & 9.39 & 8.35 & 9.67 & 8.62 & 8.19 & 6.26 & 6.06 & 8.14 \\
\hline Total & 88.36 & 88.16 & 90.44 & 89.10 & 87.65 & 88.15 & 89.74 & 89.57 & 85.81 & 87.96 \\
\hline
\end{tabular}


SRNL-STI-2013-00499

Revision 0

Appendix B. Compressive Strength Data

B-1 
Table B-1. 28 Day Compressive Strength Data.

\begin{tabular}{|c|c|c|c|c|c|}
\hline Identifier & $\begin{array}{c}\text { Sample } \\
\text { Length (in.) }\end{array}$ & $\begin{array}{c}\text { Sample } \\
\text { Diameter (in.) }\end{array}$ & $\begin{array}{c}\text { Sample } \\
\text { Mass (g) }\end{array}$ & $\begin{array}{l}\text { Maximum } \\
\text { Load (lb) }\end{array}$ & $\begin{array}{l}\text { Compressive } \\
\text { Strength (psi) }\end{array}$ \\
\hline NWS-01A & 3.996 & 2.015 & 365.0 & 1401 & 440 \\
\hline NWS-01B & 3.974 & 2.004 & 364.7 & 1678 & 530 \\
\hline NWS-01C & 3.846 & 2.008 & 356.9 & 1622 & 510 \\
\hline NWS-02A & 3.971 & 2.003 & 361.4 & 4211 & 1340 \\
\hline NWS-02B & 4.000 & 2.010 & 363.1 & 4179 & 1320 \\
\hline NWS-02C & 3.979 & 2.005 & 361.1 & 4354 & 1380 \\
\hline NWS-03A & 3.973 & 2.014 & 364.8 & 524 & 160 \\
\hline NWS-03B & 3.934 & 1.965 & 364.4 & 480 & 160 \\
\hline NWS-03C & 3.985 & 2.010 & 366.9 & 572 & 180 \\
\hline NWS-04A & 4.001 & 2.007 & 377.9 & 2068 & 650 \\
\hline NWS-04B & 3.995 & 2.006 & 378.3 & 2334 & 740 \\
\hline NWS-04C & 3.996 & 2.011 & 397.7 & 2270 & 710 \\
\hline NWS-05A & 3.979 & 2.004 & 365.4 & 1509 & 480 \\
\hline NWS-05B & 4.001 & 2.012 & 368.5 & 1670 & 530 \\
\hline NWS-05C & 4.023 & 2.012 & 368.4 & 1509 & 470 \\
\hline NWS-06A & 3.955 & 2.014 & 351.8 & 4567 & 1430 \\
\hline NWS-06B & 3.975 & 2.006 & 354.3 & 4499 & 1420 \\
\hline NWS-06C & 3.947 & 1.974 & 359.9 & 4452 & 1450 \\
\hline NWS-07A & 3.989 & 2.007 & 370.5 & 750 & 240 \\
\hline NWS-07B & 4.006 & 2.011 & 373.0 & 871 & 270 \\
\hline NWS-07C & 4.005 & 2.006 & 374.3 & 909 & 290 \\
\hline NWS-08A & 3.985 & 2.015 & 364.8 & 1791 & 560 \\
\hline NWS-08B & 3.997 & 2.014 & 370.3 & 1692 & 530 \\
\hline NWS-08C & 3.989 & 2.004 & 367.7 & 1822 & 580 \\
\hline NWS-09A & 3.968 & 2.017 & 353.6 & 2176 & 680 \\
\hline NWS-09B & 3.968 & 2.022 & 355.4 & 2097 & 650 \\
\hline NWS-09C & 3.969 & 2.015 & 354.2 & 2241 & 700 \\
\hline NWS-10A & 4.000 & 2.007 & 368.3 & 2552 & 810 \\
\hline NWS-10B & 3.988 & 2.005 & 372.3 & 2556 & 810 \\
\hline NWS-10C & 3.970 & 2.010 & 371.9 & 2776 & 870 \\
\hline NWS-11A & 3.957 & 1.999 & 354.9 & 470 & 150 \\
\hline NWS-11B & 3.960 & 2.000 & 360.4 & 1396 & 440 \\
\hline NWS-11C & 3.962 & 1.999 & 357.8 & 1177 & 380 \\
\hline NWS-12A & 3.967 & 1.995 & 362.6 & 1839 & 590 \\
\hline NWS-12B & 3.977 & 2.004 & 364.0 & 1712 & 540 \\
\hline NWS-12C & 3.974 & 2.006 & 363.4 & 1653 & 520 \\
\hline NWS-13A & 3.978 & 2.000 & 364.8 & 889 & 280 \\
\hline NWS-13B & 3.984 & 2.000 & 367.6 & 952 & 300 \\
\hline NWS-13C & 3.970 & 1.998 & 367.7 & 989 & 320 \\
\hline NWS-14A & 3.967 & 2.000 & 366.6 & 2510 & 800 \\
\hline NWS-14B & 3.981 & 2.001 & 367.2 & 2481 & 790 \\
\hline NWS-14C & 3.971 & 2.004 & 366.5 & 2557 & 810 \\
\hline NWS-15A & 3.980 & 1.997 & 366.1 & 1158 & 370 \\
\hline NWS-15B & 3.997 & 1.995 & 365.1 & 1089 & 350 \\
\hline NWS-15C & 3.987 & 1.999 & 368.1 & 1308 & 420 \\
\hline NWS-16A & 3.966 & 2.004 & 360.2 & 1557 & 490 \\
\hline
\end{tabular}


Table B-1. 28 Day Compressive Strength Data. (continued)

\begin{tabular}{||c|c|c|c|c|c||}
\hline Identifier & $\begin{array}{c}\text { Sample } \\
\text { Length (in.) }\end{array}$ & $\begin{array}{c}\text { Sample } \\
\text { Diameter (in.) }\end{array}$ & $\begin{array}{c}\text { Sample } \\
\text { Mass (g) }\end{array}$ & $\begin{array}{c}\text { Maximum } \\
\text { Load (lb) }\end{array}$ & $\begin{array}{c}\text { Compressive } \\
\text { Strength (psi) }\end{array}$ \\
\hline NWS-16B & 3.977 & 2.013 & 360.6 & 1573 & 490 \\
\hline NWS-16C & 3.973 & 2.007 & 359.5 & 1433 & 450 \\
\hline NWS-17A & 3.968 & 2.014 & 357.8 & 1267 & 400 \\
\hline NWS-17B & 3.978 & 1.997 & 358.9 & 1198 & 380 \\
\hline NWS-17C & 3.970 & 2.008 & 363.9 & 1308 & 410 \\
\hline NWS-18A & 3.962 & 2.000 & 363.4 & 6925 & 2200 \\
\hline NWS-18B & 3.965 & 1.995 & 365.5 & 6767 & 2160 \\
\hline NWS-18C & 3.969 & 1.997 & 365.7 & 7023 & 2240 \\
\hline NWS-19A & 3.974 & 2.001 & 363.2 & 3303 & 1050 \\
\hline NWS-19B & 3.980 & 2.000 & 363.0 & 3474 & 1110 \\
\hline NWS-19C & 3.963 & 2.006 & 364.9 & 3319 & 1050 \\
\hline NWS-20A & 3.969 & 2.003 & 363.0 & 1595 & 510 \\
\hline NWS-20B & 3.965 & 2.003 & 363.5 & 1620 & 510 \\
\hline NWS-20C & 3.924 & 2.006 & 359.2 & 1741 & 550 \\
\hline
\end{tabular}


Table B-2. 90 Day Compressive Strength Data.

\begin{tabular}{|c|c|c|c|c|c|}
\hline Identifier & $\begin{array}{c}\text { Sample } \\
\text { Length (in.) }\end{array}$ & $\begin{array}{c}\text { Sample } \\
\text { Diameter (in.) }\end{array}$ & $\begin{array}{c}\text { Sample Mass } \\
\text { (g) }\end{array}$ & $\begin{array}{c}\text { Maximum } \\
\text { Load (lb) }\end{array}$ & $\begin{array}{l}\text { Compressive } \\
\text { Strength (psi) }\end{array}$ \\
\hline NWS-01A & 3.982 & 2.019 & 367.8 & 3512 & 1100 \\
\hline NWS-01B & 4.044 & 2.076 & 364.3 & 3661 & 1080 \\
\hline NWS-01C & 3.980 & 2.015 & 368.5 & 3591 & 1130 \\
\hline NWS-02A & 3.972 & 2.012 & 365.9 & 8643 & 2720 \\
\hline NWS-02B & 3.973 & 2.008 & 364.5 & 8552 & 2700 \\
\hline NWS-02C & 3.975 & 2.032 & 361.3 & 8568 & 2640 \\
\hline NWS-03A & 3.975 & 2.016 & 367.5 & 1397 & 440 \\
\hline NWS-03B & 3.968 & 2.010 & 369.1 & 1494 & 470 \\
\hline NWS-03C & 3.991 & 2.025 & 371.3 & 1556 & 480 \\
\hline NWS-04A & 3.999 & 2.021 & 379.4 & 3836 & 1200 \\
\hline NWS-04B & 3.998 & 2.011 & 380.9 & 4010 & 1260 \\
\hline NWS-04C & 3.995 & 2.008 & 381.3 & 3620 & 1140 \\
\hline NWS-05A & 3.998 & 2.017 & 367.1 & 3800 & 1190 \\
\hline NWS-05B & 4.021 & 2.010 & 372.6 & 3958 & 1250 \\
\hline NWS-05C & 3.975 & 2.036 & 368.1 & 3821 & 1170 \\
\hline NWS-06A & 3.962 & 2.037 & 358.5 & 7455 & 2290 \\
\hline NWS-06B & 3.954 & 2.023 & 355.2 & 7619 & 2370 \\
\hline NWS-06C & 3.974 & 2.037 & 359.8 & 7435 & 2280 \\
\hline NWS-07A & 3.992 & 2.043 & 375.6 & 2631 & 800 \\
\hline NWS-07B & 3.977 & 2.023 & 376.7 & 2598 & 810 \\
\hline NWS-07C & 3.995 & 2.029 & 375.2 & 2528 & 780 \\
\hline NWS-08A & 3.970 & 2.013 & 369.6 & 4021 & 1260 \\
\hline NWS-08B & 3.992 & 2.010 & 368.5 & 3959 & 1250 \\
\hline NWS-08C & 3.997 & 2.013 & 371.2 & 4201 & 1320 \\
\hline NWS-09A & 3.979 & 2.020 & 356.4 & 7090 & 2210 \\
\hline NWS-09B & 3.974 & 2.010 & 354.2 & 7101 & 2240 \\
\hline NWS-09C & 3.996 & 2.018 & 359.4 & 6909 & 2160 \\
\hline NWS-10A & 3.997 & 2.031 & 370.3 & 4966 & 1530 \\
\hline NWS-10B & 3.998 & 2.035 & 371.7 & 4978 & 1530 \\
\hline NWS-10C & 3.975 & 2.022 & 375.4 & 5046 & 1570 \\
\hline NWS-11A & 3.871 & 2.012 & 357.1 & 3192 & 1000 \\
\hline NWS-11B & 3.997 & 2.015 & 360.8 & 3307 & 1040 \\
\hline NWS-11C & 3.998 & 2.015 & 366.5 & 3454 & 1080 \\
\hline NWS-12A & 3.996 & 2.019 & 364.3 & 3720 & 1160 \\
\hline NWS-12B & 3.984 & 2.017 & 366.7 & 4099 & 1280 \\
\hline NWS-12C & 3.980 & 2.015 & 364.6 & 3878 & 1220 \\
\hline NWS-13A & 3.829 & 1.847 & 367.6 & 2215 & 830 \\
\hline NWS-13B & 3.775 & 1.815 & 371.2 & 2279 & 880 \\
\hline NWS-13C & 3.981 & 2.001 & 370.8 & 2278 & 720 \\
\hline NWS-14A & 3.880 & 2.026 & 364.3 & 4298 & 1330 \\
\hline NWS-14B & 3.977 & 2.013 & 366.1 & 4317 & 1360 \\
\hline NWS-14C & 3.989 & 2.007 & 368.0 & 4267 & 1350 \\
\hline NWS-15A & 3.976 & 2.015 & 366.2 & 2113 & 660 \\
\hline NWS-15B & 3.982 & 2.009 & 369.6 & 2305 & 730 \\
\hline NWS-15C & 3.973 & 2.013 & 368.1 & 2154 & 680 \\
\hline NWS-16A & 3.996 & 2.006 & 363.2 & 530 & 170 \\
\hline NWS-16B & 3.971 & 2.013 & 365.2 & 712 & 220 \\
\hline
\end{tabular}


SRNL-STI-2013-00499

Revision 0

Table B-2. 90 Day Compressive Strength Data. (continued)

\begin{tabular}{||c|c|c|c|c|c||}
\hline Identifier & $\begin{array}{c}\text { Sample } \\
\text { Length (in.) }\end{array}$ & $\begin{array}{c}\text { Sample } \\
\text { Diameter (in.) }\end{array}$ & $\begin{array}{c}\text { Sample Mass } \\
\text { (g) }\end{array}$ & $\begin{array}{c}\text { Maximum } \\
\text { Load (lb) }\end{array}$ & $\begin{array}{c}\text { Compressive } \\
\text { Strength (psi) }\end{array}$ \\
\hline NWS-16C & 3.979 & 2.017 & 367.1 & 3964 & 1240 \\
\hline NWS-17A & 3.979 & 2.012 & 364.4 & 3561 & 1120 \\
\hline NWS-17B & 3.963 & 2.005 & 363.0 & 3668 & 1160 \\
\hline NWS-17C & 3.980 & 2.021 & 368.0 & 3780 & 1180 \\
\hline NWS-18A & 3.985 & 2.007 & 364.7 & 11017 & 3480 \\
\hline NWS-18B & 3.987 & 2.013 & 366.7 & 10938 & 3440 \\
\hline NWS-18C & 3.972 & 2.002 & 368.2 & 10926 & 3470 \\
\hline NWS-19A & 3.958 & 2.010 & 364.3 & 10281 & 3240 \\
\hline NWS-19B & 3.819 & 2.016 & 352.9 & 10185 & 3190 \\
\hline NWS-19C & 3.965 & 2.003 & 364.6 & 10192 & 3230 \\
\hline NWS-20A & 3.994 & 2.011 & 367.3 & 3890 & 1220 \\
\hline NWS-20B & 3.986 & 2.008 & 367.1 & 3991 & 1260 \\
\hline NWS-20C & 3.992 & 2.016 & 366.4 & 3878 & 1210 \\
\hline
\end{tabular}


SRNL-STI-2013-00499

Revision 0

Appendix C. Density Gradient Data 
Table C-1. Measured Values for Density Gradient Samples.

\begin{tabular}{|c|c|c|c|c|c|}
\hline Identifier & Location & $\rho_{\mathrm{A}}\left(\mathrm{g} / \mathrm{cm}^{3}\right)$ & $\rho_{\mathrm{B}}\left(\mathrm{g} / \mathrm{cm}^{3}\right)$ & $\rho_{\mathrm{C}}\left(\mathrm{g} / \mathrm{cm}^{3}\right)$ & $\rho_{\text {Sample }}\left(\mathrm{g} / \mathrm{cm}^{3}\right)$ \\
\hline NWS-01 & Top & 1.73 & 1.71 & 1.71 & 1.72 \\
\hline NWS-01 & Middle & 1.74 & 1.75 & 1.76 & 1.75 \\
\hline NWS-01 & Bottom & 1.59 & 1.63 & 1.63 & 1.62 \\
\hline NWS-02 & Top & 1.33 & 1.33 & 1.33 & 1.33 \\
\hline NWS-02 & Middle & 1.30 & 1.31 & 1.31 & 1.31 \\
\hline NWS-02 & Bottom & 1.32 & 1.33 & 1.33 & 1.33 \\
\hline NWS-03 & Top & 1.40 & 1.41 & 1.41 & 1.41 \\
\hline NWS-03 & Middle & 1.73 & 1.73 & 1.75 & 1.74 \\
\hline NWS-03 & Bottom & 1.82 & 1.81 & 1.82 & 1.82 \\
\hline NWS-04 & Top & 1.76 & 1.76 & 1.76 & 1.76 \\
\hline NWS-04 & Middle & 1.78 & 1.80 & 1.81 & 1.80 \\
\hline NWS-04 & Bottom & 1.75 & 1.77 & 1.79 & 1.77 \\
\hline NWS-05 & Top & 1.76 & 1.77 & 1.77 & 1.77 \\
\hline NWS-05 & Middle & 1.70 & 1.72 & 1.73 & 1.72 \\
\hline NWS-05 & Bottom & 1.72 & 1.73 & 1.74 & 1.73 \\
\hline NWS-06 & Top & 1.72 & 1.73 & 1.73 & 1.72 \\
\hline NWS-06 & Middle & 1.71 & 1.72 & 1.73 & 1.72 \\
\hline NWS-06 & Bottom & 1.71 & 1.72 & 1.73 & 1.72 \\
\hline NWS-07 & Top & 1.74 & 1.74 & 1.75 & 1.74 \\
\hline NWS-07 & Middle & 1.77 & 1.78 & 1.79 & 1.78 \\
\hline NWS-07 & Bottom & 1.73 & 1.75 & 1.79 & 1.76 \\
\hline NWS-08 & Top & 1.78 & 1.78 & 1.79 & 1.79 \\
\hline NWS-08 & Middle & 1.74 & 1.75 & 1.75 & 1.75 \\
\hline NWS-08 & Bottom & 1.67 & 1.69 & 1.70 & 1.69 \\
\hline NWS-09 & Top & 1.75 & 1.75 & 1.75 & 1.75 \\
\hline NWS-09 & Middle & 1.76 & 1.77 & 1.78 & 1.77 \\
\hline NWS-09 & Bottom & 1.74 & 1.75 & 1.76 & 1.75 \\
\hline NWS-10 & Top & 1.84 & 1.85 & 1.84 & 1.84 \\
\hline NWS-10 & Middle & 1.83 & 1.85 & 1.87 & 1.85 \\
\hline NWS-10 & Bottom & 1.84 & 1.85 & 1.86 & 1.85 \\
\hline NWS-11 & Top & 1.79 & 1.80 & 1.80 & 1.80 \\
\hline NWS-11 & Middle & 1.76 & 1.79 & 1.79 & 1.78 \\
\hline NWS-11 & Bottom & 1.78 & 1.80 & 1.81 & 1.80 \\
\hline NWS-12 & Top & 1.82 & 1.82 & 1.82 & 1.82 \\
\hline NWS-12 & Middle & 1.80 & 1.80 & 1.81 & 1.81 \\
\hline NWS-12 & Bottom & 1.81 & 1.82 & 1.83 & 1.82 \\
\hline NWS-13 & Top & 1.85 & 1.84 & 1.84 & 1.84 \\
\hline NWS-13 & Middle & 1.91 & 1.90 & 1.91 & 1.90 \\
\hline NWS-13 & Bottom & 1.81 & 1.82 & 1.83 & 1.82 \\
\hline NWS-14 & Top & 1.82 & 1.83 & 1.84 & 1.83 \\
\hline NWS-14 & Middle & 1.83 & 1.84 & 1.84 & 1.84 \\
\hline NWS-14 & Bottom & 1.84 & 1.84 & 1.85 & 1.84 \\
\hline NWS-15 & Top & 1.82 & 1.82 & 1.83 & 1.82 \\
\hline NWS-15 & Middle & 1.82 & 1.83 & 1.83 & 1.83 \\
\hline NWS-15 & Bottom & 1.82 & 1.83 & 1.84 & 1.83 \\
\hline NWS-16 & Top & 1.79 & 1.80 & 1.80 & 1.80 \\
\hline NWS-16 & Middle & 1.79 & 1.79 & 1.80 & 1.79 \\
\hline
\end{tabular}


Table C-1. Measured Values for Density Gradient Samples. (continued)

\begin{tabular}{||c|c|c|c|c|c||}
\hline Identifier & Location & $\rho_{\mathbf{A}}\left(\mathbf{g} / \mathbf{c m}^{\mathbf{3}}\right)$ & $\rho_{\mathbf{B}}\left(\mathbf{g} / \mathbf{c m}^{\mathbf{3}}\right)$ & $\rho_{\mathbf{C}}\left(\mathbf{g} / \mathbf{c m}^{\mathbf{3}}\right)$ & $\rho_{\text {Sample }}\left(\mathbf{g} / \mathbf{c m}^{\mathbf{3}}\right)$ \\
\hline NWS-16 & Bottom & 1.79 & 1.79 & 1.80 & 1.79 \\
\hline NWS-17 & Top & 1.78 & 1.78 & 1.79 & 1.78 \\
\hline NWS-17 & Middle & 1.77 & 1.78 & 1.78 & 1.78 \\
\hline NWS-17 & Bottom & 1.79 & 1.80 & 1.80 & 1.80 \\
\hline NWS-18 & Top & 1.81 & 1.81 & 1.82 & 1.82 \\
\hline NWS-18 & Middle & 1.82 & 1.82 & 1.83 & 1.82 \\
\hline NWS-18 & Bottom & 1.81 & 1.81 & 1.83 & 1.82 \\
\hline NWS-19 & Top & 1.81 & 1.81 & 1.82 & 1.81 \\
\hline NWS-19 & Middle & 1.80 & 1.81 & 1.82 & 1.81 \\
\hline NWS-19 & Bottom & 1.80 & 1.81 & 1.81 & 1.81 \\
\hline NWS-20 & Top & 1.80 & 1.80 & 1.81 & 1.81 \\
\hline NWS-20 & Middle & 1.77 & 1.80 & 1.81 & 1.79 \\
\hline NWS-20 & Bottom & 1.79 & 1.82 & 1.83 & 1.81 \\
\hline
\end{tabular}


Exhibit C-1. Analysis of Variance for Density Gradient Measurements.

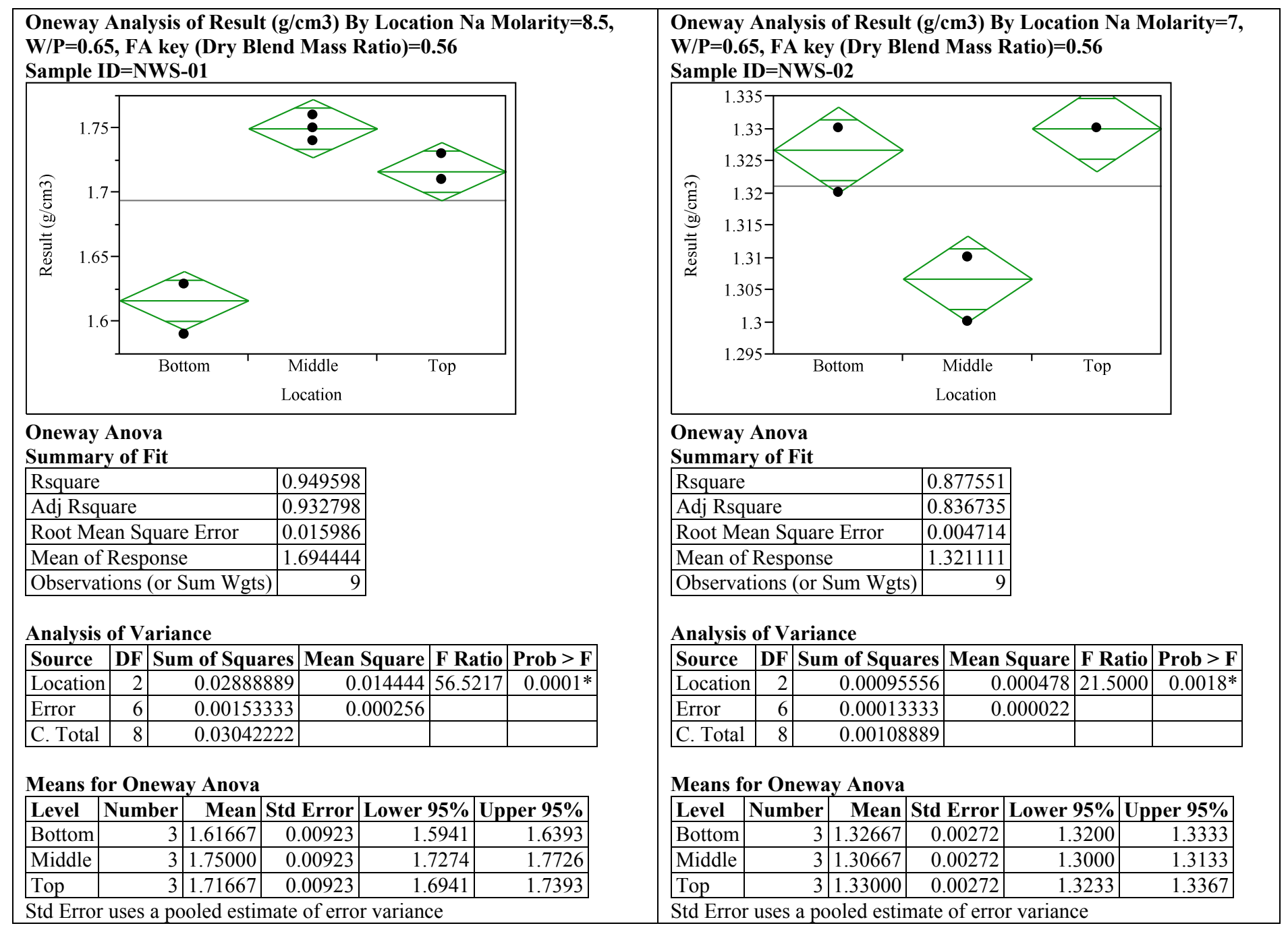


Exhibit C-1. Analysis of Variance for Density Gradient Measurements. (continued)

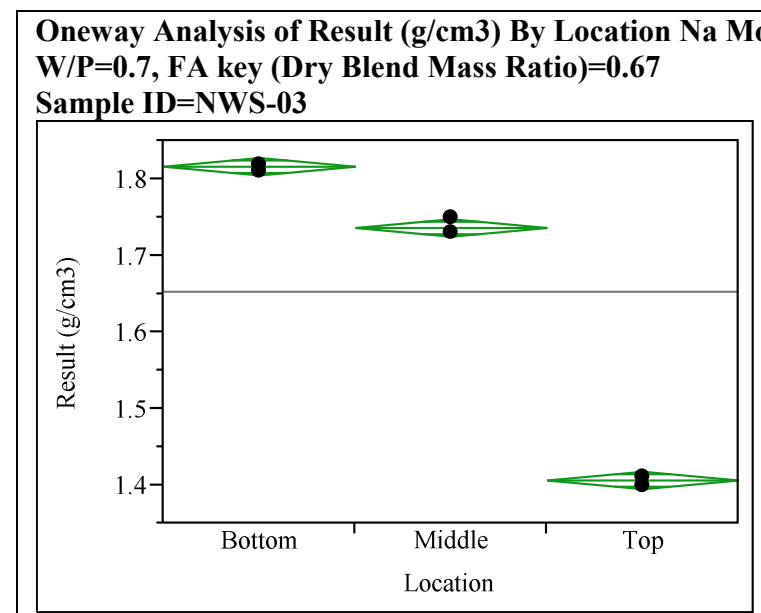

\section{Oneway Anova}

\section{Summary of Fit}

Rsquare

Adj Rsquare

Root Mean Square Error

Mean of Response

\begin{tabular}{|l|r|}
\hline Observations (or Sum Wgts) & 9 \\
\hline
\end{tabular}

Analysis of Variance

\begin{tabular}{|l|l|l|l|l|l|}
\hline Source & DF & Sum of Squares & Mean Square & F Ratio & Prob > F \\
\hline
\end{tabular}

\begin{tabular}{|l|r|r|r|r|r|}
\hline Location & 2 & 0.28340000 & 0.141700 & 2125.500 & $<.0001^{*}$ \\
\hline Error & 6 & 0.00040000 & 0.000067 & & \\
\hline C. Total & 8 & 0.28380000 & & & \\
\hline
\end{tabular}

Means for Oneway Anova

\begin{tabular}{|l|r|r|r|r|r|}
\hline Level & Number & Mean & Std Error & Lower 95\% & Upper 95\% \\
\hline
\end{tabular}

\begin{tabular}{|l|r|r|r|r|r|}
\hline Bottom & 3 & 1.81667 & 0.00471 & 1.8051 & 1.8282 \\
\hline Middle & 3 & 1.73667 & 0.00471 & 1.7251 & 1.7482 \\
\hline Top & 3 & 1.40667 & 0.00471 & 1.3951 & 1.4182 \\
\hline
\end{tabular}

Std Error uses a pooled estimate of error variance

Oneway Analysis of Result (g/cm3) By Location Na Molarity=10,

$\mathrm{W} / \mathrm{P}=0.6$, FA key (Dry Blend Mass Ratio) $=0.45$

Sample ID $=$ NWS-04

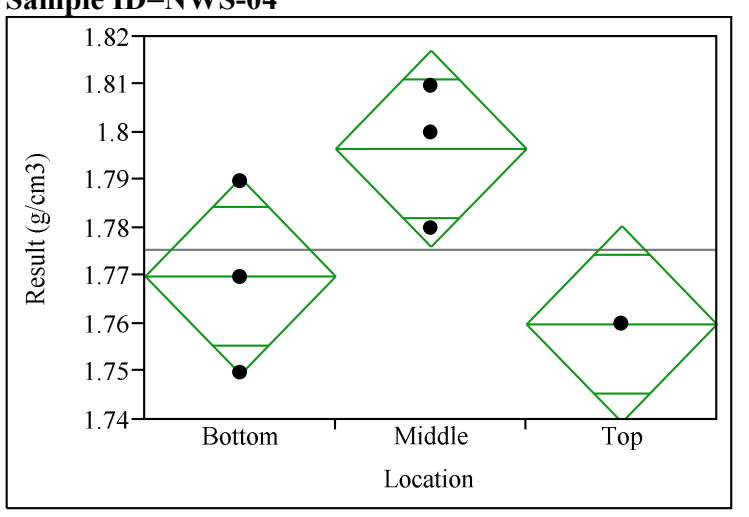

Oneway Anova

Summary of Fit

Rsquare

0.506494

\begin{tabular}{|l|r|}
\hline Root Mean Square Error & 0.01453 \\
\hline
\end{tabular}

Mean of Response

\begin{tabular}{|l|r|}
\hline Observations (or Sum Wgts) & 9 \\
\hline
\end{tabular}

Analysis of Variance

\begin{tabular}{|l|r|r|r|r|r|}
\hline Source & DF & Sum of Squares & Mean Square & F Ratio & Prob $>$ F \\
\hline
\end{tabular}

\begin{tabular}{|l|r|r|r|r|r|}
\hline Location & 2 & 0.00215556 & 0.001078 & 5.1053 & 0.0507 \\
\hline Error & 6 & 0.00126667 & 0.000211 & & \\
\hline C. Total & 8 & 0.00342222 & & & \\
\hline
\end{tabular}

Means for Oneway Anova

\begin{tabular}{|l|r|r|r|r|r|}
\hline Level & Number & Mean & Std Error & Lower 95\% & Upper 95\% \\
\hline
\end{tabular}

\begin{tabular}{|l|r|r|r|r|r|}
\hline Bottom & 3 & 1.77000 & 0.00839 & 1.7495 & 1.7905 \\
\hline Middle & 3 & 1.79667 & 0.00839 & 1.7761 & 1.8172 \\
\hline
\end{tabular}

\begin{tabular}{|l|l|l|l|l|l|}
\hline Middle & 3 & 1.79667 & 0.00839 & 1.7761 & 1.8172 \\
\hline Top & 3 & 1.76000 & 0.00839 & 1.7395 & 1.7805 \\
\hline
\end{tabular}

Std Error uses a pooled estimate of error variance 
Exhibit C-1. Analysis of Variance for Density Gradient Measurements. (continued)

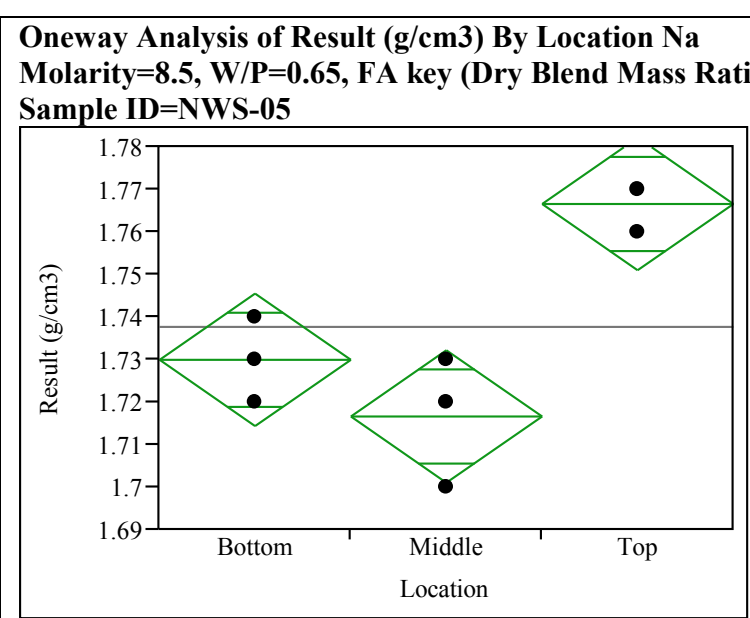

Oneway Anova

\section{Summary of Fit}

Rsquare

Adj Rsquare

Root Mean Square Error

Mean of Response

0.794393

1.737778

\begin{tabular}{|l|r|}
\hline Observations (or Sum Wgts) & 9 \\
\hline
\end{tabular}

Analysis of Variance

\begin{tabular}{|l|r|l|l|l|l|}
\hline Source & DF & Sum of Squares & Mean Square & F Ratio & Prob > F \\
\hline
\end{tabular} \begin{tabular}{|l|r|r|r|r|r|}
\hline Source & DF & Sum of Squares & Mean Square & F Ratio & Prob > F \\
\hline Location & 2 & 0.00402222 & 0.002011 & 16.4545 & $0.0037^{*}$ \\
\hline
\end{tabular} \begin{tabular}{ll|l|l|l|l}
\hline Error & 6 & 0.00073333 \\
\hline
\end{tabular}

\begin{tabular}{|l|r|r|r|r|r|}
\hline Error & 6 & 0.00073333 & 0.000122 & & \\
\hline C. Total & 8 & 0.00475556 & & & \\
\hline
\end{tabular}

Means for Oneway Anova

\begin{tabular}{|l|l|l|l|l|l|}
\hline Level & Number & Mean & Std Error & Lower 95\% & Upper 95\% \\
\hline
\end{tabular}

\begin{tabular}{|l|r|r|r|r|r|}
\hline Bottom & 3 & 1.73000 & 0.00638 & 1.7144 & 1.7456 \\
\hline Middle & 3 & 1.71667 & 0.00638 & 1.7010 & 1.7323 \\
\hline Top & 3 & 1.76667 & 0.00638 & 1.7510 & 1.7823 \\
\hline
\end{tabular}

\begin{tabular}{lr|r|r|r|}
\hline Top & 3 & 1.76667 & 0.00638 & 1.75 \\
\hline Std Error uses a pooled estimate of error variance
\end{tabular}

Oneway Analysis of Result (g/cm3) By Location Na Molarity=7, $\mathrm{W} / \mathrm{P}=\mathbf{0 . 7}$, FA key (Dry Blend Mass Ratio) $=0.45$ Sample ID=NWS-06

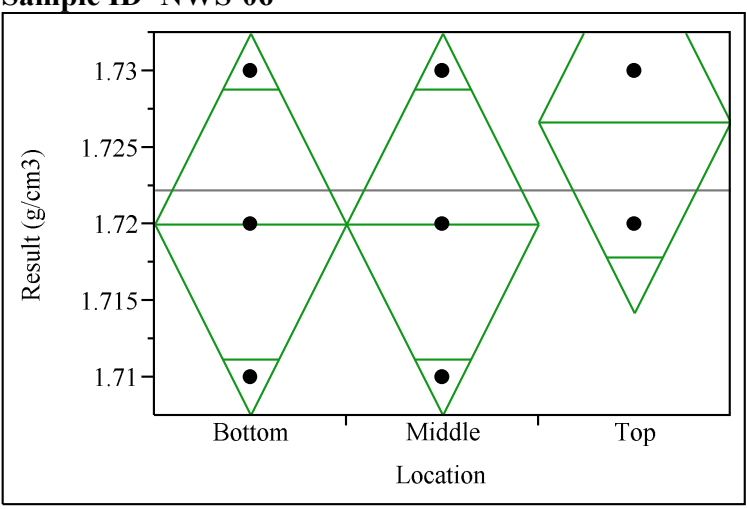

Oneway Anova

Summary of Fit

Rsquare

\begin{tabular}{|r|r|}
\hline Root Mean Square Error & -0.12 \\
\hline
\end{tabular}

Mean of Response

\begin{tabular}{|l|r|}
\hline Observations (or Sum Wgts) & 9 \\
\hline
\end{tabular}

Analysis of Variance

\begin{tabular}{|l|r|r|r|r|r|}
\hline Source & DF & Sum of Squares & Mean Square & F Ratio & Prob > F \\
\hline
\end{tabular}

\begin{tabular}{|l|r|r|r|r|r|}
\hline Location & 2 & 0.00008889 & 0.000044 & 0.5714 & 0.5927 \\
\hline Error & 6 & 0.00046667 & 0.000078 & & \\
\hline C. Total & 8 & 0.00055556 & & & \\
\hline
\end{tabular}

Means for Oneway Anova

\begin{tabular}{|l|r|r|r|r|r|}
\hline Level & Number & Mean & Std Error & Lower 95\% & Upper 95\% \\
\hline
\end{tabular}

\begin{tabular}{|l|r|r|r|r|r|}
\hline Bottom & 3 & 1.72000 & 0.00509 & 1.7075 & 1.7325 \\
\hline Middle & 3 & 1.72000 & 0.00509 & 1.7075 & 1.7325 \\
\hline Top & 3 & 1.72667 & 0.00509 & 1.7142 & 1.7391 \\
\hline
\end{tabular}

\begin{tabular}{|l|l|l|l|l|l|}
\hline Top & 3 & 1.72667 & 0.00509 & 1.7142 & 1.7391 \\
\hline
\end{tabular}

Std Error uses a pooled estimate of error variance 
Exhibit C-1. Analysis of Variance for Density Gradient Measurements. (continued)

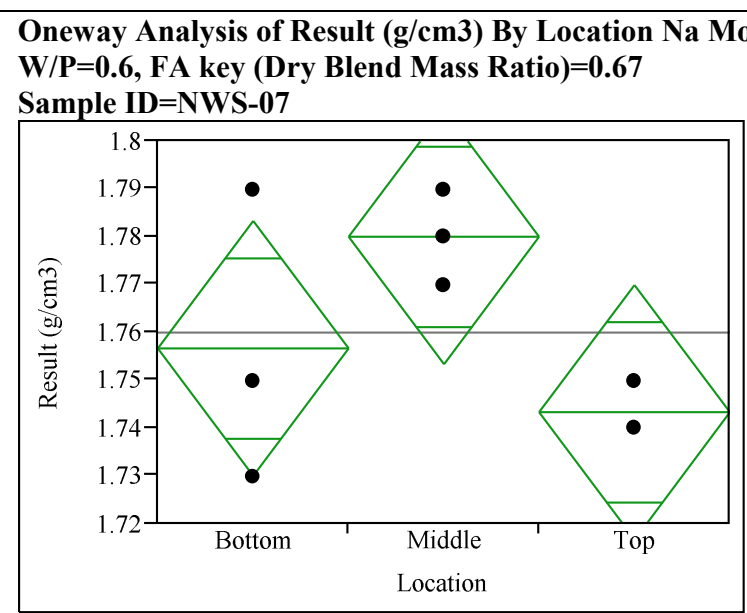

Oneway Anova

\section{Summary of Fit}

Rsquare

it

Adj Rsquare

0.492063

Root Mean Square Error

0.322751

Mean of Response

Observations (or Sum Wgts)

Analysis of Variance

\begin{tabular}{|l|r|l|l|l|l|}
\hline Source & DF & Sum of Squares & Mean Square & F Ratio & Prob > F \\
\hline
\end{tabular}

\begin{tabular}{|l|r|r|r|r|r|}
\hline Location & 2 & 0.00206667 & 0.001033 & 2.9062 & 0.1310 \\
\hline Error & 6 & 0.00213333 & 0.000356 & & \\
\hline C. Total & 8 & 0.00420000 & & & \\
\hline
\end{tabular}

\section{Means for Oneway Anova}

\begin{tabular}{|l|r|r|r|r|r|}
\hline Level & Number & Mean & Std Error & Lower 95\% & Upper 95\% \\
\hline
\end{tabular}

\begin{tabular}{|l|r|r|r|r|r|}
\hline Bottom & 3 & 1.75667 & 0.01089 & 1.7300 & 1.7833 \\
\hline Middle & 3 & 1.78000 & 0.01089 & 1.7534 & 1.8066 \\
\hline Top & 3 & 1.74333 & 0.01089 & 1.7167 & 1.7700 \\
\hline
\end{tabular}

Std Error uses a pooled estimate of error variance

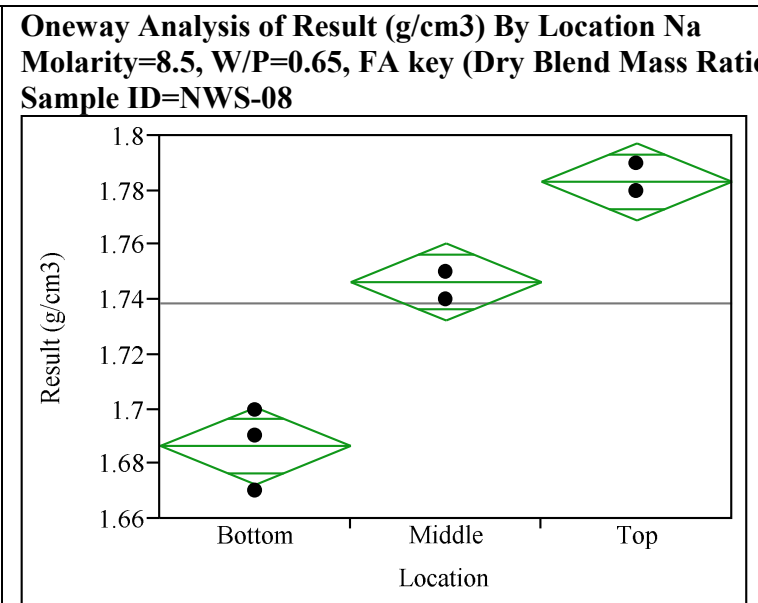

\section{Oneway Anova}

Summary of Fit

Rsquare

\begin{tabular}{|r|r|} 
& 0.959701 \\
\hline & 0.946269 \\
\hline
\end{tabular}

Root Mean Square Error

Mean of Response

\begin{tabular}{|l|r|}
\hline Observations (or Sum Wgts) & 1.738889 \\
\hline
\end{tabular}

\section{Analysis of Variance}

\begin{tabular}{|l|l|l|l|l|l|}
\hline Source & DF & Sum of Squares & Mean Square & F Ratio & Prob $>$ F \\
\hline
\end{tabular}

\begin{tabular}{|l|r|r|r|r|r|}
\hline Location & 2 & 0.01428889 & 0.007144 & 71.4444 & $<.0001^{*}$ \\
\hline Error & 6 & 0.00060000 & 0.000100 & & \\
\hline C. Total & 8 & 0.01488889 & & & \\
\hline
\end{tabular}

\section{Means for Oneway Anova}

\begin{tabular}{|l|r|r|r|r|r|}
\hline Level & Number & Mean & Std Error & Lower 95\% & Upper 95\% \\
\hline
\end{tabular}

\begin{tabular}{|l|r|r|r|r|r|}
\hline Bottom & 3 & 1.68667 & 0.00577 & 1.6725 & 1.7008 \\
\hline Middle & 3 & 1.74667 & 0.00577 & 1.7325 & 1.7608 \\
\hline Top & 3 & 1.78333 & 0.00577 & 1.7692 & 1.7975 \\
\hline
\end{tabular}

Std Error uses a pooled estimate of error variance 
Exhibit C-1. Analysis of Variance for Density Gradient Measurements. (continued)

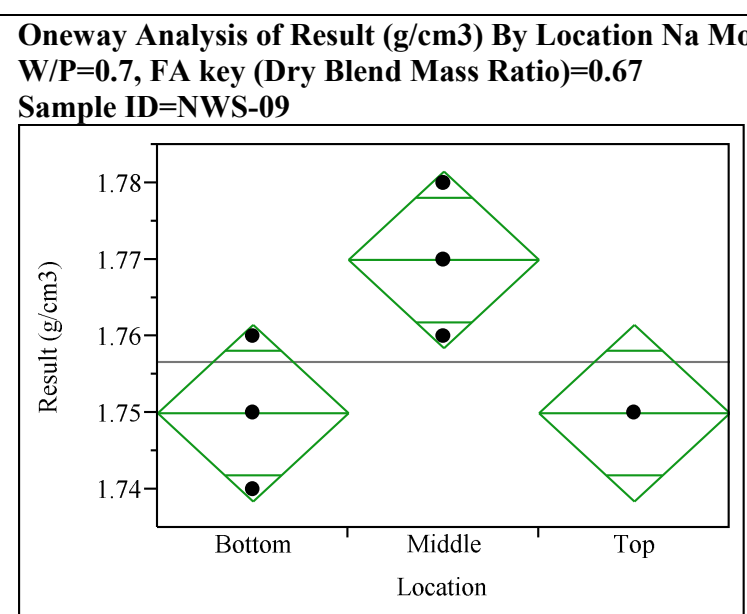

Oneway Anova

Summary of Fit

Rsquare

Adj Rsquare

Root Mean Square Error

Mean of Response

0.555556

1.756667

\begin{tabular}{|l|r|}
\hline Observations (or Sum Wgts) & 9 \\
\hline
\end{tabular}

Analysis of Variance

\begin{tabular}{|l|r|r|r|r|r|}
\hline Source & DF & Sum of Squares & Mean Square & F Ratio & Prob > F \\
\hline
\end{tabular}

\begin{tabular}{|l|r|r|r|r|r|}
\hline Source & DF & Sum of Squares & Mean Square & F Ratio & Prob > F \\
\hline Location & 2 & 0.00080000 & 0.000400 & 6.0000 & $0.0370^{*}$ \\
\hline
\end{tabular}

\begin{tabular}{l|r|r|r|}
\hline Error & 6 & 0.00040000 \\
\hline
\end{tabular}

\begin{tabular}{|l|r|r|r|r|r|}
\hline C. Total & 8 & 0.00120000 & & & \\
\hline
\end{tabular}

Means for Oneway Anova

\begin{tabular}{|l|r|r|r|r|r|}
\hline Level & Number & Mean & Std Error & Lower 95\% & Upper 95\% \\
\hline
\end{tabular}

\begin{tabular}{|l|r|r|r|r|r|}
\hline Bottom & 3 & 1.75000 & 0.00471 & 1.7385 & 1.7615 \\
\hline Middle & 3 & 1.77000 & 0.00471 & 1.7585 & 1.7815 \\
\hline Top & 3 & 1.75000 & 0.00471 & 1.7385 & 1.7615 \\
\hline
\end{tabular}

\begin{tabular}{lr|r|r|r|}
\hline Top & 3 & 1.75000 & 0.00471 & 1.7385 \\
\hline Std Error uses a pooled estimate of error variance
\end{tabular}

1.7615

Oneway Analysis of Result (g/cm3) By Location Na

Molarity $=8.5, W / P=0.6$, FA key (Dry Blend Mass Ratio) $=0.56$

Sample ID=NWS-10

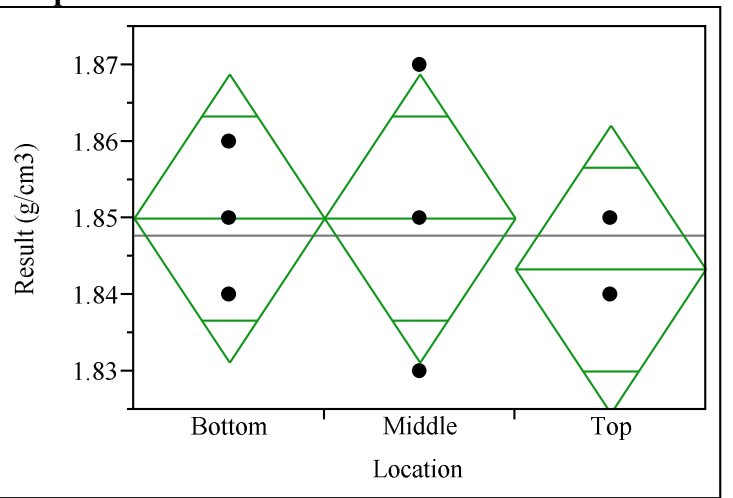

Oneway Anova

Summary of Fit

Rsquare

Adj Rsquare

\begin{tabular}{|l|l|}
\hline Root Mean Square Error & 0.013333 \\
\hline Mean of Response & 1.847778 \\
\hline
\end{tabular}

\begin{tabular}{|l|r|}
\hline Observations (or Sum Wgts) & 9 \\
\hline
\end{tabular}

Analysis of Variance

\begin{tabular}{|l|r|r|r|r|r|}
\hline Source & DF & Sum of Squares & Mean Square & F Ratio & Prob $>$ F \\
\hline
\end{tabular}

\begin{tabular}{|l|r|r|r|r|r|}
\hline Location & 2 & 0.00008889 & 0.000044 & 0.2500 & 0.7865 \\
\hline Error & 6 & 0.00106667 & 0.000178 & & \\
\hline C. Total & 8 & 0.00115556 & & & \\
\hline
\end{tabular}

Means for Oneway Anova

\begin{tabular}{|l|r|r|r|r|r|}
\hline Level & Number & Mean & Std Error & Lower 95\% & Upper 95\% \\
\hline
\end{tabular}

\begin{tabular}{|l|r|r|r|r|r|}
\hline Bottom & 3 & 1.85000 & 0.00770 & 1.8312 & 1.8688 \\
\hline Middle & 3 & 1.85000 & 0.00770 & 1.8312 & 1.8688 \\
\hline Top & 3 & 1.84333 & 0.00770 & 1.8245 & 1.8622 \\
\hline
\end{tabular}

\begin{tabular}{|l|l|l|l|l|l|}
\hline Top & 3 & 1.84333 & 0.00770 & 1.8245 & 1.8622 \\
\hline
\end{tabular}

Std Error uses a pooled estimate of error variance 
Exhibit C-1. Analysis of Variance for Density Gradient Measurements. (continued)

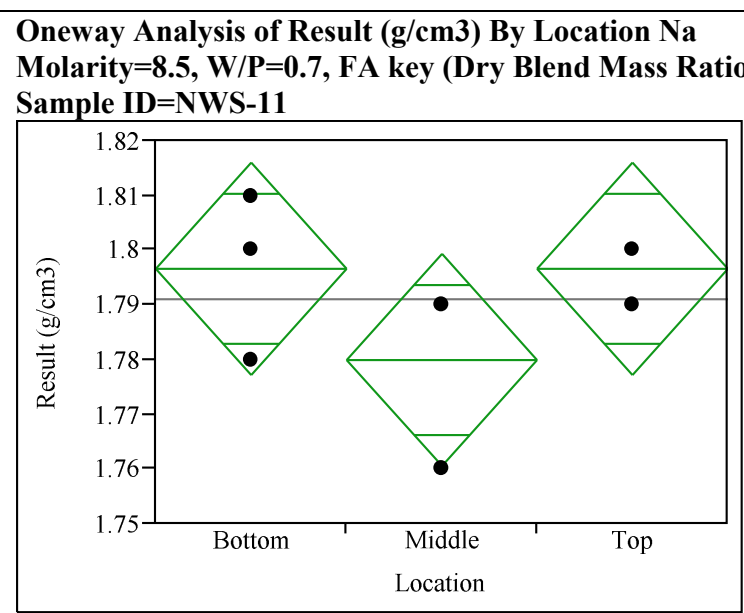

Oneway Anova

\section{Summary of Fit}

Rsquare

Adj Rsquare

Root Mean Square Error

Mean of Response

0.105263

\begin{tabular}{|l|r|}
\hline Observations (or Sum Wgts) & 9 \\
\hline
\end{tabular}

Analysis of Variance

\begin{tabular}{|l|r|r|r|r|r|}
\hline Source & DF & Sum of Squares & Mean Square & F Ratio & Prob > F \\
\hline
\end{tabular}

\begin{tabular}{|l|r|r|r|r|r|}
\hline Source & DF & Sum of Squares & Mean Square & F Ratio & Prob > F \\
\hline Location & 2 & 0.00055556 & 0.000278 & 1.4706 & 0.3022 \\
\hline
\end{tabular}

\begin{tabular}{|l|r|r|r|r|r|}
\hline Error & 6 & 0.00113333 & 0.000189 & & \\
\hline C. Total & 8 & 0.00168889 & & & \\
\hline
\end{tabular}

\begin{tabular}{|l|r|r|}
\hline C. Total & 8 & 0.00168889 \\
\hline
\end{tabular}

Means for Oneway Anova

\begin{tabular}{|l|r|r|r|r|r|}
\hline Level & Number & Mean & Std Error & Lower 95\% & Upper 95\% \\
\hline
\end{tabular}

\begin{tabular}{|l|r|r|r|r|r|}
\hline Bottom & 3 & 1.79667 & 0.00793 & 1.7773 & 1.8161 \\
\hline Middle & 3 & 1.78000 & 0.00793 & 1.7606 & 1.7994 \\
\hline Top & 3 & 1.79667 & 0.00793 & 1.7773 & 1.8161 \\
\hline
\end{tabular}

\begin{tabular}{lr|r|r|r|}
\hline Top & 3 & 1.79667 & 0.00793 & 1.7773 \\
\hline Std Error uses a pooled estimate of error variance
\end{tabular}

Oneway Analysis of Result (g/cm3) By Location Na

Molarity $=8.5, \mathrm{~W} / \mathrm{P}=0.65, \mathrm{FA}$ key $($ Dry Blend Mass Ratio $)=0.56$

Sample ID $=$ NWS-12

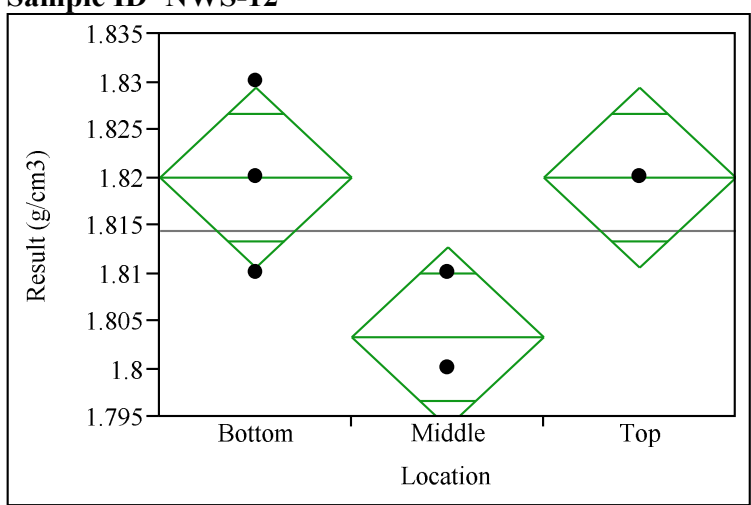

Oneway Anova

Summary of Fit

Rsquare

\begin{tabular}{l|l|}
0.567568 \\
\hline
\end{tabular}

\begin{tabular}{|l|l|}
\hline Root Mean Square Error & 0.006667 \\
\hline Mean of Response & 1.814444 \\
\hline
\end{tabular}

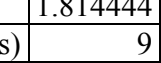

Analysis of Variance

\begin{tabular}{|l|l|l|l|l|l|}
\hline Source & DF & Sum of Squares & Mean Square & F Ratio & Prob $>$ F \\
\hline
\end{tabular}

\begin{tabular}{|l|r|r|r|r|r|}
\hline Location & 2 & 0.00055556 & 0.000278 & 6.2500 & $0.0341^{*}$ \\
\hline Error & 6 & 0.00026667 & 0.000044 & & \\
\hline C. Total & 8 & 0.00082222 & & & \\
\hline
\end{tabular}

Means for Oneway Anova

\begin{tabular}{|l|r|r|r|r|r|}
\hline Level & Number & Mean & Std Error & Lower 95\% & Upper 95\% \\
\hline
\end{tabular}

\begin{tabular}{|l|r|r|r|r|r|}
\hline Bottom & 3 & 1.82000 & 0.00385 & 1.8106 & 1.8294 \\
\hline
\end{tabular}

\begin{tabular}{|l|l|l|l|l|l|}
\hline Middle & 3 & 1.80333 & 0.00385 & 1.7939 & 1.8128 \\
\hline
\end{tabular}

\begin{tabular}{|l|r|r|r|r|r|}
\hline Top & 3 & 1.82000 & 0.00385 & 1.8106 & 1.8294 \\
\hline
\end{tabular}

Std Error uses a pooled estimate of error variance 
Exhibit C-1. Analysis of Variance for Density Gradient Measurements. (continued)

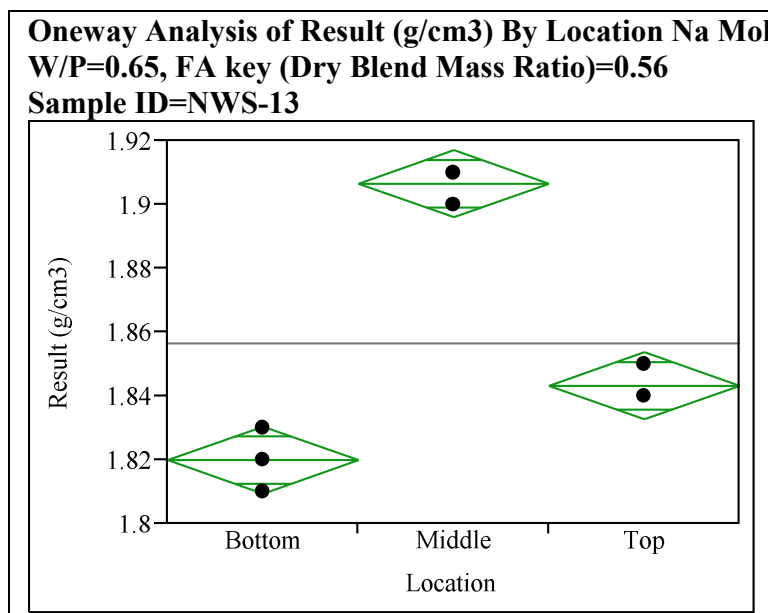

\section{Oneway Anova}

Summary of Fit

\begin{tabular}{|l|r|}
\hline Rsquare & 0.973118 \\
\hline Adj Rsquare & 0.964158 \\
\hline Root Mean Square Error & 0.007454 \\
\hline Mean of Response & 1.856667 \\
\hline Observations (or Sum Wgts) & 9 \\
\hline
\end{tabular}

Observations (or Sum

\begin{tabular}{|l|l|l|l|l|l|}
\hline Source & DF & Sum of Squares & Mean Square & F Ratio & Prob > F \\
\hline
\end{tabular}

\begin{tabular}{|l|r|r|r|r|r|}
\hline Source & DF & Sum of Squares & Mean Square & F Ratio & Prob > F \\
\hline Location & 2 & 0.01206667 & 0.006033 & 108.6000 & $<.0001^{*}$ \\
\hline Error & 6 & 0.00033333 & 0.000056 & & \\
\hline C. Total & 8 & 0.01240000 & & & \\
\hline
\end{tabular}

Means for Oneway Anova

\begin{tabular}{|l|r|r|r|r|r|}
\hline Level & Number & Mean & Std Error & Lower 95\% & Upper 95\% \\
\hline
\end{tabular}

\begin{tabular}{|l|r|r|r|r|r|}
\hline Level & Number & Mean & Std Error & Lower 95\% & Upper 95\% \\
\hline Bottom & 3 & 1.82000 & 0.00430 & 1.8095 & 1.8305 \\
\hline Middle & 3 & 1.90667 & 0.00430 & 1.8961 & 1.9172 \\
\hline Top & 3 & 1.84333 & 0.00430 & 1.8328 & 1.8539 \\
\hline
\end{tabular}

\begin{tabular}{|lr|r|r|r|}
\hline Top & 3 & 1.84333 & 0.00430 & 1.8328 \\
\hline Std Error uses a pooled estimate of error variance
\end{tabular}

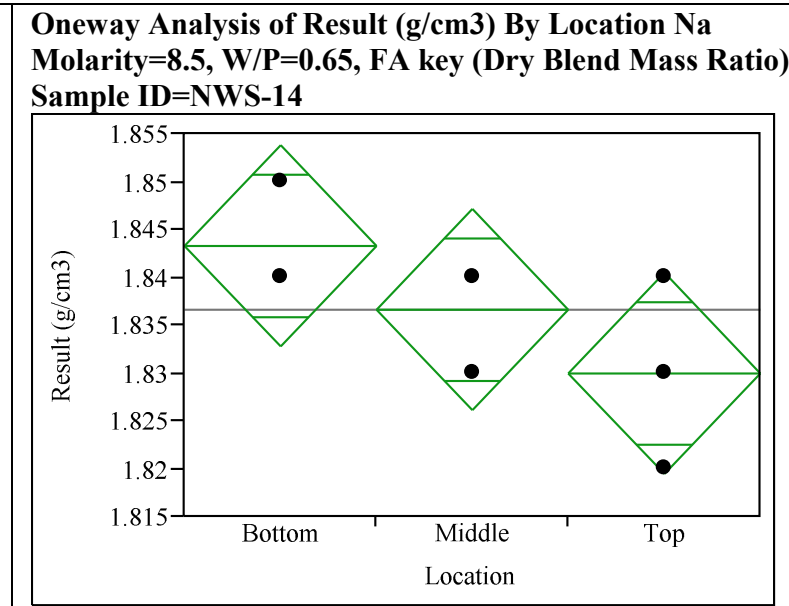

\section{Oneway Anova}

Summary of Fit

\begin{tabular}{|l|r|}
\hline Rsquare & 0.444444 \\
\hline Adj Rsquare & 0.259259 \\
\hline Root Mean Square Error & 0.007454 \\
\hline Mean of Response & 1.836667 \\
\hline Observations (or Sum Wgts) & 9 \\
\hline
\end{tabular}

Analysis of Variance

\begin{tabular}{|l|l|l|l|l|l|}
\hline Source & DF & Sum of Squares & Mean Square & F Ratio & Prob > F \\
\hline
\end{tabular} \begin{tabular}{|l|r|r|r|r|r|}
\hline Source & DF & Sum of Squares & Mean Square & F Ratio & Prob > F \\
\hline Location & 2 & 0.00026667 & 0.000133 & 2.4000 & 0.1715 \\
\hline
\end{tabular}

\begin{tabular}{|l|r|r|r|r|r|}
\hline Error & 6 & 0.00033333 & 0.000056 & & \\
\hline C. Total & 8 & 0.00060000 & & & \\
\hline
\end{tabular}

Means for Oneway Anova

\begin{tabular}{|l|r|r|r|r|r|}
\hline Level & Number & Mean & Std Error & Lower 95\% & Upper 95\% \\
\hline
\end{tabular}

\begin{tabular}{|l|r|r|r|r|r|}
\hline Level & Number & Mean & Std Error & Lower 95\% & Upper 95\% \\
\hline Bottom & 3 & 1.84333 & 0.00430 & 1.8328 & 1.8539 \\
\hline Middle & 3 & 1.83667 & 0.00430 & 1.8261 & 1.8472 \\
\hline Top & 3 & 1.83000 & 0.00430 & 1.8195 & 1.8405 \\
\hline
\end{tabular}

Std Error uses a pooled estimate of error variance 
Exhibit C-1. Analysis of Variance for Density Gradient Measurements. (continued)

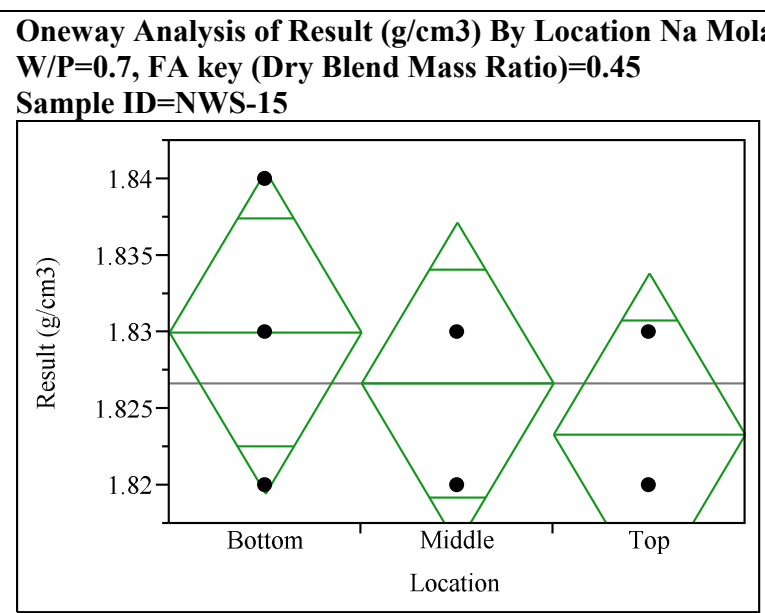

Oneway Anova

Summary of Fit

Rsquare

Adj Rsquare

$\mid 0.166667$

Root Mean Square Error

Mean of Response

$-0.11111$

\begin{tabular}{|c|c|}
\hline & 0.007454 \\
\hline
\end{tabular}

\begin{tabular}{|l|r|}
\hline Observations (or Sum Wgts) & 9 \\
\hline
\end{tabular}

Analysis of Variance

\begin{tabular}{|l|r|r|r|r|r|}
\hline Source & DF & Sum of Squares & Mean Square & F Ratio & Prob > F \\
\hline
\end{tabular}

\begin{tabular}{|l|r|r|r|r|r|}
\hline Location & 2 & 0.00006667 & 0.000033 & 0.6000 & 0.5787 \\
\hline Error & 6 & 0.00033333 & 0.000056 & & \\
\hline
\end{tabular}

\begin{tabular}{|l|r|r|r|}
\hline Error & 6 & 0.00033333 & 0.000056 \\
\hline
\end{tabular}

\begin{tabular}{|l|r|r|r|r|r|}
\hline C. Total & 8 & 0.00040000 & & & \\
\hline
\end{tabular}

Means for Oneway Anova

\begin{tabular}{|l|r|r|r|r|r|}
\hline Level & Number & Mean & Std Error & Lower 95\% & Upper 95\% \\
\hline
\end{tabular}

\begin{tabular}{|l|r|r|r|r|r|}
\hline Bottom & 3 & 1.83000 & 0.00430 & 1.8195 & 1.8405 \\
\hline Middle & 3 & 1.82667 & 0.00430 & 1.8161 & 1.8372 \\
\hline Top & 3 & 1.82333 & 0.00430 & 1.8128 & 1.8339 \\
\hline
\end{tabular}

\begin{tabular}{|lr|r|r|r|}
\hline Top & 3 & 1.82333 & 0.00430 & 1.8128 \\
\hline Std Error uses a pooled estimate of error variance
\end{tabular}

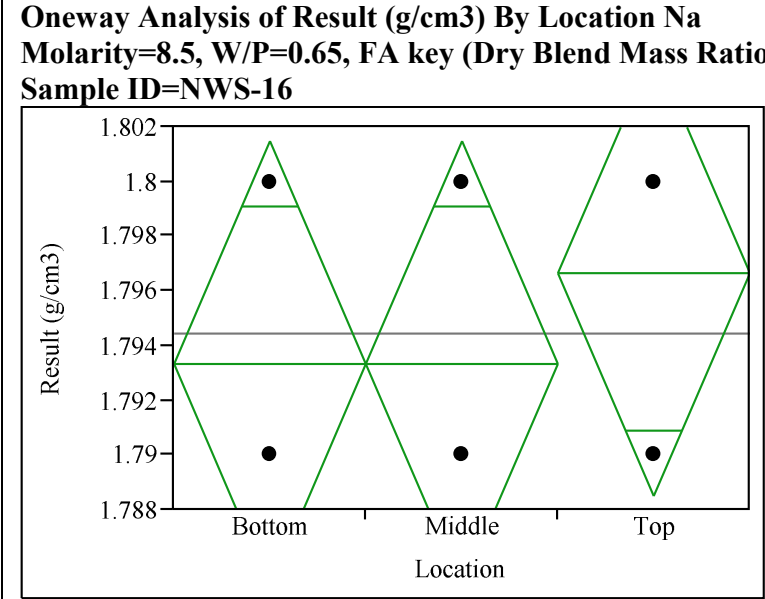

Oneway Anova

Summary of Fit

Rsquare

\begin{tabular}{|r|r|}
\hline Root Mean Square Error & -0.005774 \\
\hline
\end{tabular}

Mean of Response

\begin{tabular}{|l|r|}
\hline Observations (or Sum Wgts) & 9 \\
\hline
\end{tabular}

Analysis of Variance

\begin{tabular}{|l|l|l|l|l|l|}
\hline Source & DF & Sum of Squares & Mean Square & F Ratio & Prob $>$ F \\
\hline
\end{tabular}

\begin{tabular}{|l|r|r|r|r|r|}
\hline Location & 2 & 0.00002222 & 0.000011 & 0.3333 & 0.7290 \\
\hline Error & 6 & 0.00020000 & 0.000033 & & \\
\hline C. Total & 8 & 0.00022222 & & & \\
\hline
\end{tabular}

Means for Oneway Anova

\begin{tabular}{|l|r|r|r|r|r|}
\hline Level & Number & Mean & Std Error & Lower 95\% & Upper 95\% \\
\hline
\end{tabular}

\begin{tabular}{|l|r|r|r|r|r|}
\hline Level & Number & Mean & Std Error & Lower 95\% & Upper 95\% \\
\hline Bottom & 3 & 1.79333 & 0.00333 & 1.7852 & 1.8015 \\
\hline Middle & 3 & 1.79333 & 0.00333 & 1.7852 & 1.8015 \\
\hline Top & 3 & 1.79667 & 0.00333 & 1.7885 & 1.8048 \\
\hline
\end{tabular}

\begin{tabular}{|l|r|r|r|r}
\hline Top & 3 & 1.79667 & 0.00333 & 1.7885 \\
\hline Std Error uses a pooled estimate of error variance
\end{tabular} 
Exhibit C-1. Analysis of Variance for Density Gradient Measurements. (continued)

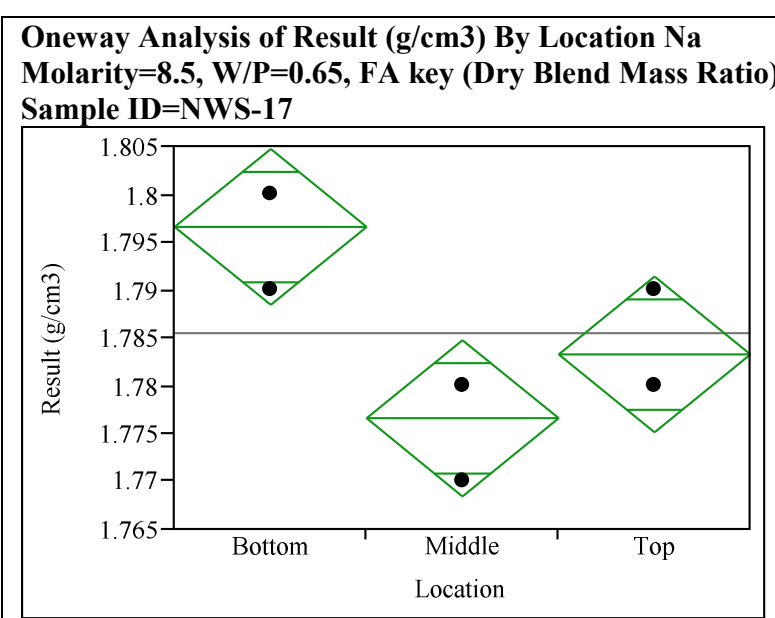

Oneway Anova

Summary of Fit

Rsquare

Adj Rsquare

\begin{tabular}{|l|l|}
\hline & 0.756757 \\
\hline & 0.675676 \\
\hline
\end{tabular}

Root Mean Square Error

Mean of Response

\begin{tabular}{|l|r|}
\hline Observations (or Sum Wgts) & 9 \\
\hline
\end{tabular}

Analysis of Variance

\begin{tabular}{|l|r|r|r|r|r|}
\hline Source & DF & Sum of Squares & Mean Square & F Ratio & Prob > F \\
\hline
\end{tabular}

\begin{tabular}{|l|r|r|r|r|r|}
\hline Location & 2 & 0.00062222 & 0.000311 & 9.3333 & $0.0144^{*}$ \\
\hline Error & 6 & 0.00020000 & 0.000033 & & \\
\hline C. Total & 8 & 0.00082222 & & & \\
\hline
\end{tabular}

Means for Oneway Anova

\begin{tabular}{|l|l|l|l|l|l|}
\hline Level & Number & Mean & Std Error & Lower 95\% & Upper 95\% \\
\hline
\end{tabular}

\begin{tabular}{|l|r|r|r|r|r|}
\hline Bottom & 3 & 1.79667 & 0.00333 & 1.7885 & 1.8048 \\
\hline Middle & 3 & 1.77667 & 0.00333 & 1.7685 & 1.7848 \\
\hline Top & 3 & 1.78333 & 0.00333 & 1.7752 & 1.7915 \\
\hline
\end{tabular}

\begin{tabular}{|l|l|l|l|l|r|}
\hline Middle & 3 & 1.77667 & 0.00333 & 1.7685 & 1.7848 \\
\hline Top & 3 & 1.78333 & 0.00333 & 1.7752 & 1.7915 \\
\hline
\end{tabular}

Std Error uses a pooled estimate of error variance

Oneway Analysis of Result (g/cm3) By Location Na Molarity=7,

$\mathrm{W} / \mathrm{P}=\mathbf{0 . 6}$, FA key (Dry Blend Mass Ratio) $=0.45$

Sample ID $=$ NWS-18

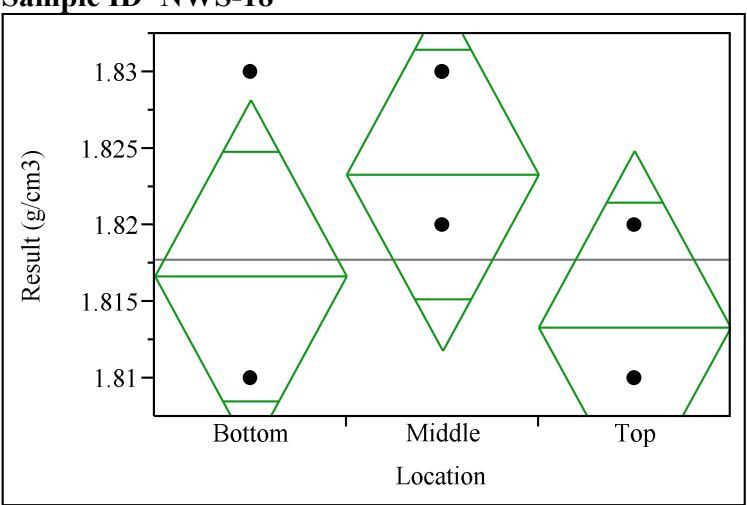

Oneway Anova

Summary of Fit

Rsquare

\begin{tabular}{|r|r|}
\hline Root Mean Square Error & 0.008165 \\
\hline
\end{tabular}

Mean of Response

\begin{tabular}{|l|r|}
\hline Observations (or Sum Wgts) & 9 \\
\hline
\end{tabular}

Analysis of Variance

\begin{tabular}{|l|r|r|r|r|r|}
\hline Source & DF & Sum of Squares & Mean Square & F Ratio & Prob > F \\
\hline
\end{tabular}

\begin{tabular}{|l|r|r|r|r|r|}
\hline Location & 2 & 0.00015556 & 0.000078 & 1.1667 & 0.3732 \\
\hline Error & 6 & 0.00040000 & 0.000067 & & \\
\hline C. Total & 8 & 0.00055556 & & & \\
\hline
\end{tabular}

Means for Oneway Anova

\begin{tabular}{|l|r|r|r|r|r|}
\hline Level & Number & Mean & Std Error & Lower 95\% & Upper 95\% \\
\hline Botom & & &
\end{tabular}

\begin{tabular}{|l|r|r|r|r|r|}
\hline Bottom & 3 & 1.81667 & 0.00471 & 1.8051 & 1.8282 \\
\hline Middle & 3 & 1.82333 & 0.00471 & 1.8118 & 1.8349 \\
\hline Top & 3 & 1.81333 & 0.00471 & 1.8018 & 1.8249 \\
\hline
\end{tabular}

\begin{tabular}{|l|l|l|l|l|l|}
\hline Middle & 3 & 1.82333 & 0.00471 & 1.8118 & 1.8349 \\
\hline Top & 3 & 1.81333 & 0.00471 & 1.8018 & 1.8249 \\
\hline
\end{tabular}

Std Error uses a pooled estimate of error variance 
Exhibit C-1. Analysis of Variance for Density Gradient Measurements. (continued)

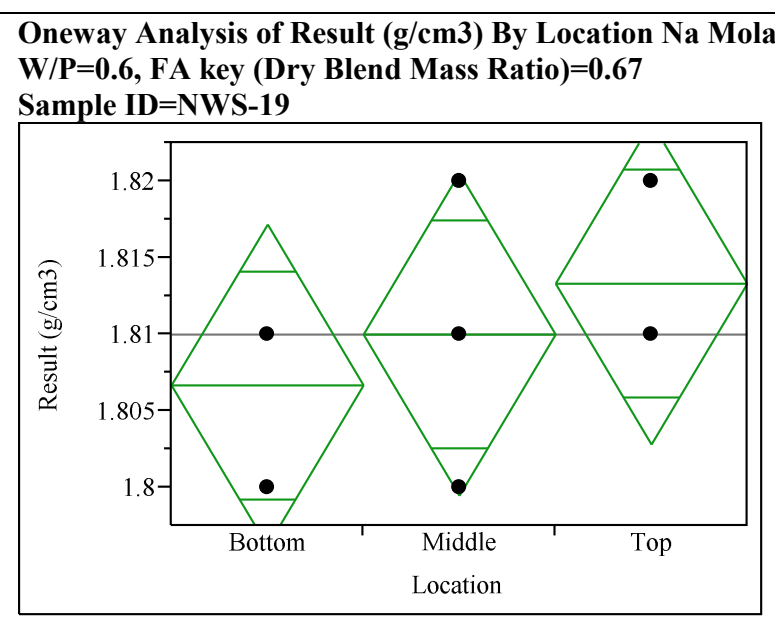

Oneway Anova

Summary of Fit

\begin{tabular}{|l|r|}
\hline Rsquare & 0.166667 \\
\hline Adj Rsquare & -0.11111 \\
\hline Root Mean Square Error & 0.007454 \\
\hline Mean of Response & 1.81 \\
\hline Observations (or Sum Wgts) & 9 \\
\hline
\end{tabular}

Analysis of Variance

\begin{tabular}{|l|r|r|r|r|r|}
\hline Source & DF & Sum of Squares & Mean Square & F Ratio & Prob > F \\
\hline
\end{tabular}

\begin{tabular}{|l|r|r|r|r|r|}
\hline Location & 2 & 0.00006667 & 0.000033 & 0.6000 & 0.5787 \\
\hline Error & 6 & 0.00033333 & 0.000056 & & \\
\hline C. Total & 8 & 0.00040000 & & & \\
\hline
\end{tabular}

\section{Means for Oneway Anova}

\begin{tabular}{|l|r|r|r|r|r|}
\hline Level & Number & Mean & Std Error & Lower 95\% & Upper 95\% \\
\hline
\end{tabular}

\begin{tabular}{|l|r|r|r|r|r|}
\hline Bottom & 3 & 1.80667 & 0.00430 & 1.7961 & 1.8172 \\
\hline Middle & 3 & 1.81000 & 0.00430 & 1.7995 & 1.8205 \\
\hline Top & 3 & 1.81333 & 0.00430 & 1.8028 & 1.8239 \\
\hline
\end{tabular}

\begin{tabular}{lr|r|r|r|}
\hline Top & 3 & 1.81333 & 0.00430 & 1.8028 \\
\hline Std Error uses a pooled estimate of error variance
\end{tabular}

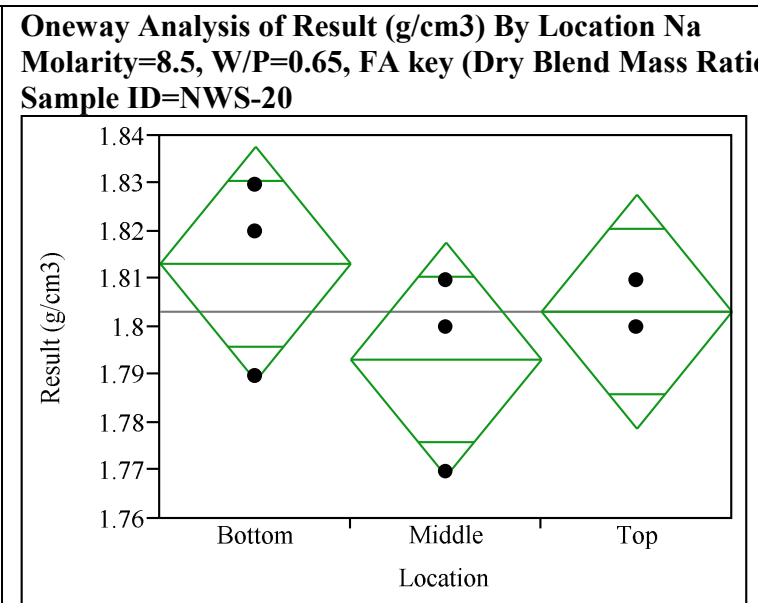

Oneway Anova

Summary of Fit

Rsquare

\begin{tabular}{l|r} 
& $-7.3 \mathrm{e}-15$ \\
\hline Root Mean Square Error & 0.017321 \\
\hline
\end{tabular}

\begin{tabular}{|l|r|}
\hline Root Mean Square Error & 0.017321 \\
\hline Mean of Response & 1.803333 \\
\hline
\end{tabular}

\begin{tabular}{|l|r|}
\hline Observations (or Sum Wgts) & 9 \\
\hline
\end{tabular}

Analysis of Variance

\begin{tabular}{|l|r|r|r|r|r|}
\hline Source & DF & Sum of Squares & Mean Square & F Ratio & Prob $>$ F \\
\hline
\end{tabular}

\begin{tabular}{|l|r|r|r|r|r|}
\hline Location & 2 & 0.00060000 & 0.000300 & 1.0000 & 0.4219 \\
\hline Error & 6 & 0.00180000 & 0.000300 & & \\
\hline C. Total & 8 & 0.00240000 & & & \\
\hline
\end{tabular}

Means for Oneway Anova

\begin{tabular}{|l|l|l|l|l|l|}
\hline Level & Number & Mean & Std Error & Lower 95\% & Upper 95\% \\
\hline
\end{tabular}

\begin{tabular}{|l|r|r|r|r|r|}
\hline Bottom & 3 & 1.81333 & 0.01000 & 1.7889 & 1.8378 \\
\hline Middle & 3 & 1.79333 & 0.01000 & 1.7689 & 1.8178 \\
\hline Top & 3 & 1.80333 & 0.01000 & 1.7789 & 1.8278 \\
\hline
\end{tabular}

Std Error uses a pooled estimate of error variance 
SRNL-STI-2013-00499

Revision 0

Appendix D. Leach Index Data

D-1 
Table D-1. Leach Index Data for the Test Mixes.

\begin{tabular}{|c|c|c|c|c|}
\hline Identifier & Component & $\begin{array}{c}\text { Leach Index, } \\
\text { Replicate } 1 \\
\end{array}$ & $\begin{array}{c}\text { Leach Index, } \\
\text { Replicate } 2 \\
\end{array}$ & Mean Leach Index \\
\hline NWS-01 & $\mathrm{Al}$ & 12.8 & 12.9 & 12.9 \\
\hline NWS-01 & $\mathrm{Ca}$ & 14.2 & 14.3 & 14.3 \\
\hline NWS-01 & $\mathrm{Cl}$ & $>9$ & $>9$ & $>9$ \\
\hline NWS-01 & $\mathrm{Cr}$ & $>12.7$ & $>12.7$ & $>12.7$ \\
\hline NWS-01 & I & 9.1 & 9.1 & 9.1 \\
\hline NWS-01 & $\mathrm{K}$ & 9.6 & 9.7 & 9.7 \\
\hline NWS-01 & $\mathrm{Na}$ & 9.3 & 9.4 & 9.4 \\
\hline NWS-01 & $\mathrm{NO} 2$ & 9.3 & 9.3 & 9.3 \\
\hline NWS-01 & NO3 & 9.2 & 9.3 & 9.3 \\
\hline NWS-01 & $\mathrm{S}$ & 9.2 & 9.3 & 9.3 \\
\hline NWS-01 & $\mathrm{Si}$ & 13.4 & 13.5 & 13.5 \\
\hline NWS-02 & $\mathrm{Al}$ & 12.6 & 12.7 & 12.7 \\
\hline NWS-02 & $\mathrm{Ca}$ & 14.1 & 14.2 & 14.2 \\
\hline NWS-02 & $\mathrm{Cl}$ & $>8.9$ & $>9$ & $>8.9$ \\
\hline NWS-02 & $\mathrm{Cr}$ & $>12.5$ & $>12.5$ & $>12.5$ \\
\hline NWS-02 & I & 9 & 9.1 & 9.1 \\
\hline NWS-02 & $\mathrm{K}$ & 9.6 & 9.7 & 9.7 \\
\hline NWS-02 & $\mathrm{Na}$ & 9.3 & 9.3 & 9.3 \\
\hline NWS-02 & $\mathrm{NO} 2$ & 9.3 & 9.3 & 9.3 \\
\hline NWS-02 & NO3 & 9 & 9.1 & 9.1 \\
\hline NWS-02 & $\mathrm{S}$ & 9.4 & 9.4 & 9.4 \\
\hline NWS-02 & $\mathrm{Si}$ & 13.6 & 13.7 & 13.7 \\
\hline NWS-03 & $\mathrm{Al}$ & 12.7 & 12.7 & 12.7 \\
\hline NWS-03 & $\mathrm{Ca}$ & 14.1 & 14.3 & 14.2 \\
\hline NWS-03 & $\mathrm{Cl}$ & $>8.6$ & $>8.7$ & $>8.6$ \\
\hline NWS-03 & $\mathrm{Cr}$ & $>12.3$ & $>12$ & $>12$ \\
\hline NWS-03 & $\mathrm{I}$ & 9.5 & 9.5 & 9.5 \\
\hline NWS-03 & $\mathrm{K}$ & 9.4 & 9.5 & 9.5 \\
\hline NWS-03 & $\mathrm{Na}$ & 9.2 & 9.2 & 9.2 \\
\hline NWS-03 & $\mathrm{NO} 2$ & 9.2 & 9.3 & 9.3 \\
\hline NWS-03 & NO3 & 9 & 9 & 9.0 \\
\hline NWS-03 & $\mathrm{S}$ & 8.8 & 8.8 & 8.8 \\
\hline NWS-03 & $\mathrm{Si}$ & 13 & 13.1 & 13.1 \\
\hline NWS-04 & $\mathrm{Al}$ & 12.7 & 12.8 & 12.8 \\
\hline NWS-04 & $\mathrm{Ca}$ & 14.5 & 14.5 & 14.5 \\
\hline NWS-04 & $\mathrm{Cl}$ & $>9.2$ & $>9.2$ & $>9.2$ \\
\hline NWS-04 & $\mathrm{Cr}$ & $>12.4$ & $>12.7$ & $>12.4$ \\
\hline NWS-04 & I & 9.3 & 9.4 & 9.4 \\
\hline NWS-04 & $\mathrm{K}$ & 9.6 & 9.7 & 9.7 \\
\hline NWS-04 & $\mathrm{Na}$ & 9.4 & 9.5 & 9.5 \\
\hline NWS-04 & $\mathrm{NO} 2$ & 9.5 & 9.6 & 9.6 \\
\hline NWS-04 & NO3 & 9.4 & 9.4 & 9.4 \\
\hline NWS-04 & $\mathrm{S}$ & 9.3 & 9.4 & 9.4 \\
\hline NWS-04 & $\mathrm{Si}$ & 13.3 & 13.4 & 13.4 \\
\hline NWS-05 & $\mathrm{Al}$ & 12.8 & 12.8 & 12.8 \\
\hline NWS-05 & $\mathrm{Ca}$ & 14.3 & 14.5 & 14.4 \\
\hline
\end{tabular}


Table D-1. Leach Index Data for the Test Mixes. (continued)

\begin{tabular}{|c|c|c|c|c|}
\hline Identifier & Component & $\begin{array}{c}\text { Leach Index, } \\
\text { Replicate } 1\end{array}$ & $\begin{array}{c}\text { Leach Index, } \\
\text { Replicate } 2\end{array}$ & Mean Leach Index \\
\hline NWS-05 & $\mathrm{Cl}$ & $>9$ & $>9$ & $>9$ \\
\hline NWS-05 & $\mathrm{Cr}$ & $>12.6$ & $>12.6$ & $>12.6$ \\
\hline NWS-05 & $\bar{I}$ & 9.1 & 9.1 & 9.1 \\
\hline NWS-05 & $\mathrm{K}$ & 9.6 & 9.6 & 9.6 \\
\hline NWS-05 & $\mathrm{Na}$ & 9.3 & 9.4 & 9.4 \\
\hline NWS-05 & NO2 & 9.4 & 9.3 & 9.4 \\
\hline NWS-05 & NO3 & 9.2 & 9.2 & 9.2 \\
\hline NWS-05 & $\mathrm{S}$ & 9.3 & 9.3 & 9.3 \\
\hline NWS-05 & $\mathrm{Si}$ & 13.4 & 13.4 & 13.4 \\
\hline NWS-06 & $\mathrm{Al}$ & 12.6 & 12.7 & 12.7 \\
\hline NWS-06 & $\mathrm{Ca}$ & 13.9 & 14 & 14.0 \\
\hline NWS-06 & $\mathrm{Cl}$ & $>9$ & $>9.1$ & $>9$ \\
\hline NWS-06 & $\mathrm{Cr}$ & $>12.6$ & $>12.6$ & $>12.6$ \\
\hline NWS-06 & $\mathrm{I}$ & 9.1 & 9.2 & 9.2 \\
\hline NWS-06 & $\mathrm{K}$ & 9.8 & 9.8 & 9.8 \\
\hline NWS-06 & $\mathrm{Na}$ & 9.4 & 9.3 & 9.4 \\
\hline NWS-06 & NO2 & 9.2 & 9.3 & 9.3 \\
\hline NWS-06 & $\mathrm{NO3}$ & 9.2 & 9.2 & 9.2 \\
\hline NWS-06 & $\mathrm{S}$ & 9.5 & 9.6 & 9.6 \\
\hline NWS-06 & $\mathrm{Si}$ & 13.7 & 13.7 & 13.7 \\
\hline NWS-07 & $\mathrm{Al}$ & 12.8 & 12.8 & 12.8 \\
\hline NWS-07 & $\mathrm{Ca}$ & 14.1 & 14.2 & 14.2 \\
\hline NWS-07 & $\mathrm{Cl}$ & $>8.7$ & $>8.7$ & $>8.7$ \\
\hline NWS-07 & $\mathrm{Cr}$ & $>12.6$ & $>12.5$ & $>12.5$ \\
\hline NWS-07 & I & 8.7 & 8.7 & 8.7 \\
\hline NWS-07 & $\mathrm{K}$ & 9.3 & 9.3 & 9.3 \\
\hline NWS-07 & $\mathrm{Na}$ & 9.2 & 9.2 & 9.2 \\
\hline NWS-07 & $\mathrm{NO} 2$ & 8.8 & 8.8 & 8.8 \\
\hline NWS-07 & NO3 & 8.8 & 8.8 & 8.8 \\
\hline NWS-07 & $\mathrm{S}$ & 8.8 & 8.9 & 8.9 \\
\hline NWS-07 & $\mathrm{Si}$ & 13.3 & 13.2 & 13.3 \\
\hline NWS-08 & $\mathrm{Al}$ & 12.8 & 12.8 & 12.8 \\
\hline NWS-08 & $\mathrm{Ca}$ & 14.2 & 14.2 & 14.2 \\
\hline NWS-08 & $\mathrm{Cl}$ & $>9.1$ & $>9.1$ & $>9.1$ \\
\hline NWS-08 & $\mathrm{Cr}$ & $>12.6$ & $>12.6$ & $>12.6$ \\
\hline NWS-08 & I & 9.1 & 9.1 & 9.1 \\
\hline NWS-08 & $\mathrm{K}$ & 9.6 & 9.6 & 9.6 \\
\hline NWS-08 & $\mathrm{Na}$ & 9.3 & 9.3 & 9.3 \\
\hline NWS-08 & NO2 & 9.4 & 9.4 & 9.4 \\
\hline NWS-08 & NO3 & 9.2 & 9.2 & 9.2 \\
\hline NWS-08 & $\mathrm{S}$ & 9.2 & 9.2 & 9.2 \\
\hline NWS-08 & $\mathrm{Si}$ & 13.4 & 13.5 & 13.5 \\
\hline NWS-09 & $\mathrm{Al}$ & 12.7 & 12.7 & 12.7 \\
\hline NWS-09 & $\mathrm{Ca}$ & 13.9 & 13.9 & 13.9 \\
\hline NWS-09 & $\mathrm{Cl}$ & $>8.8$ & $>8.8$ & $>8.8$ \\
\hline NWS-09 & $\mathrm{Cr}$ & $>12.7$ & $>12.7$ & $>12.7$ \\
\hline NWS-09 & I & 8.8 & 8.8 & 8.8 \\
\hline
\end{tabular}


Table D-1. Leach Index Data for the Test Mixes. (continued)

\begin{tabular}{|c|c|c|c|c|}
\hline Identifier & Component & $\begin{array}{c}\text { Leach Index, } \\
\text { Replicate } 1\end{array}$ & $\begin{array}{c}\text { Leach Index, } \\
\text { Replicate } 2\end{array}$ & Mean Leach Index \\
\hline NWS-09 & $\mathrm{K}$ & 9.6 & 9.5 & 9.6 \\
\hline NWS-09 & $\mathrm{Na}$ & 9.3 & 9.2 & 9.3 \\
\hline NWS-09 & $\mathrm{NO} 2$ & 9 & 9 & 9.0 \\
\hline NWS-09 & NO3 & 9 & 8.9 & 9.0 \\
\hline NWS-09 & $\mathrm{S}$ & 9.2 & 9.2 & 9.2 \\
\hline NWS-09 & $\mathrm{Si}$ & 13.6 & 13.6 & 13.6 \\
\hline NWS-10 & $\mathrm{Al}$ & 12.8 & 12.9 & 12.9 \\
\hline NWS-10 & $\mathrm{Ca}$ & 14.6 & 14.6 & 14.6 \\
\hline NWS-10 & $\mathrm{Cl}$ & $>9.1$ & $>9.1$ & $>9.1$ \\
\hline NWS-10 & $\mathrm{Cr}$ & $>12.8$ & $>12.8$ & $>12.8$ \\
\hline NWS-10 & $\mathrm{I}$ & 9.3 & 9.3 & 9.3 \\
\hline NWS-10 & $\mathrm{K}$ & 9.7 & 9.7 & 9.7 \\
\hline NWS-10 & $\mathrm{Na}$ & 9.5 & 9.5 & 9.5 \\
\hline NWS-10 & $\mathrm{NO} 2$ & 9.5 & 9.6 & 9.6 \\
\hline NWS-10 & NO3 & 9.3 & 9.3 & 9.3 \\
\hline NWS-10 & $\mathrm{S}$ & 9.4 & 9.4 & 9.4 \\
\hline NWS-10 & $\mathrm{Si}$ & 13.5 & 13.5 & 13.5 \\
\hline NWS-11 & $\mathrm{Al}$ & 12.9 & 12.9 & 12.9 \\
\hline NWS-11 & $\mathrm{Ca}$ & 14.3 & 14.3 & 14.3 \\
\hline NWS-11 & $\mathrm{Cl}$ & $>9$ & $>9$ & $>9$ \\
\hline NWS-11 & $\mathrm{Cr}$ & $>12.7$ & $>12.7$ & $>12.7$ \\
\hline NWS-11 & I & 9.1 & 9 & 9.1 \\
\hline NWS-11 & $\mathrm{K}$ & 9.6 & 9.6 & 9.6 \\
\hline NWS-11 & $\mathrm{Na}$ & 9.4 & 9.4 & 9.4 \\
\hline NWS-11 & $\mathrm{NO} 2$ & 9.4 & 9.3 & 9.4 \\
\hline NWS-11 & $\mathrm{NO3}$ & 9.2 & 9.2 & 9.2 \\
\hline NWS-11 & $\mathrm{S}$ & 9.1 & 9.2 & 9.2 \\
\hline NWS-11 & $\mathrm{Si}$ & 13.5 & 13.5 & 13.5 \\
\hline NWS-12 & $\mathrm{Al}$ & 12.9 & 12.9 & 12.9 \\
\hline NWS-12 & $\mathrm{Ca}$ & 14.3 & 14.5 & 14.4 \\
\hline NWS-12 & $\mathrm{Cl}$ & $>9.1$ & $>9.1$ & $>9.1$ \\
\hline NWS-12 & $\mathrm{Cr}$ & $>12.6$ & $>12.6$ & $>12.6$ \\
\hline NWS-12 & I & 9.3 & 9.3 & 9.3 \\
\hline NWS-12 & $\mathrm{K}$ & 9.7 & 9.7 & 9.7 \\
\hline NWS-12 & $\mathrm{Na}$ & 9.5 & 9.5 & 9.5 \\
\hline NWS-12 & NO2 & 9.5 & 9.6 & 9.6 \\
\hline NWS-12 & NO3 & 9.4 & 9.4 & 9.4 \\
\hline NWS-12 & $\mathrm{S}$ & 9.2 & 9.3 & 9.3 \\
\hline NWS-12 & $\mathrm{Si}$ & 13.5 & 13.6 & 13.6 \\
\hline NWS-13 & $\mathrm{Al}$ & 12.9 & 12.8 & 12.9 \\
\hline NWS-13 & $\mathrm{Ca}$ & 14.4 & 14.3 & 14.4 \\
\hline NWS-13 & $\mathrm{Cl}$ & $>9$ & $>9$ & $>9$ \\
\hline NWS-13 & $\mathrm{Cr}$ & $>12.8$ & $>12.8$ & $>12.8$ \\
\hline NWS-13 & I & 9 & 8.9 & 9.0 \\
\hline NWS-13 & $\mathrm{K}$ & 9.5 & 9.4 & 9.5 \\
\hline NWS-13 & $\mathrm{Na}$ & 9.4 & 9.3 & 9.4 \\
\hline NWS-13 & $\mathrm{NO} 2$ & 9.2 & 9.1 & 9.2 \\
\hline
\end{tabular}


Table D-1. Leach Index Data for the Test Mixes. (continued)

\begin{tabular}{|c|c|c|c|c|}
\hline Identifier & Component & $\begin{array}{c}\text { Leach Index, } \\
\text { Replicate } 1\end{array}$ & $\begin{array}{c}\text { Leach Index, } \\
\text { Replicate 2 }\end{array}$ & Mean Leach Index \\
\hline NWS-13 & NO3 & 9.1 & 9.2 & 9.2 \\
\hline NWS-13 & $\mathrm{S}$ & 9.1 & 9 & 9.1 \\
\hline NWS-13 & $\mathrm{Si}$ & 13.5 & 13.4 & 13.5 \\
\hline NWS-14 & $\mathrm{Al}$ & 12.8 & 12.8 & 12.8 \\
\hline NWS-14 & $\mathrm{Ca}$ & 14.6 & 14.5 & 14.6 \\
\hline NWS-14 & $\mathrm{Cl}$ & $>9.2$ & $>9.2$ & $>9.2$ \\
\hline NWS-14 & $\mathrm{Cr}$ & $>12.6$ & $>12.6$ & $>12.6$ \\
\hline NWS-14 & I & 9.4 & 9.4 & 9.4 \\
\hline NWS-14 & $\mathrm{K}$ & 9.8 & 9.8 & 9.8 \\
\hline NWS-14 & $\mathrm{Na}$ & 9.5 & 9.5 & 9.5 \\
\hline NWS-14 & NO2 & 9.6 & 9.6 & 9.6 \\
\hline NWS-14 & NO3 & 9.5 & 9.5 & 9.5 \\
\hline NWS-14 & $\mathrm{S}$ & 9.4 & 9.4 & 9.4 \\
\hline NWS-14 & $\mathrm{Si}$ & 13.5 & 13.5 & 13.5 \\
\hline NWS-15 & $\mathrm{Al}$ & 12.7 & 12.8 & 12.8 \\
\hline NWS-15 & $\mathrm{Ca}$ & 14.4 & 14.6 & 14.5 \\
\hline NWS-15 & $\mathrm{Cl}$ & $>9.2$ & $>9.2$ & $>9.2$ \\
\hline NWS-15 & $\mathrm{Cr}$ & $>12.8$ & $>12.8$ & $>12.8$ \\
\hline NWS-15 & I & 9.3 & 9.3 & 9.3 \\
\hline NWS-15 & $\mathrm{K}$ & 9.7 & 9.7 & 9.7 \\
\hline NWS-15 & $\mathrm{Na}$ & 9.6 & 9.5 & 9.6 \\
\hline NWS-15 & $\mathrm{NO} 2$ & 9.6 & 9.5 & 9.6 \\
\hline NWS-15 & $\mathrm{NO3}$ & 9.5 & 9.4 & 9.5 \\
\hline NWS-15 & $\mathrm{S}$ & 9.3 & 9.3 & 9.3 \\
\hline NWS-15 & $\mathrm{Si}$ & 13.5 & 13.5 & 13.5 \\
\hline NWS-16 & $\mathrm{Al}$ & 13 & 13 & 13.0 \\
\hline NWS-16 & $\mathrm{Ca}$ & 14.1 & 14.1 & 14.1 \\
\hline NWS-16 & $\mathrm{Cl}$ & $>9.1$ & $>9.1$ & $>9.1$ \\
\hline NWS-16 & $\mathrm{Cr}$ & $>12.7$ & $>12.7$ & $>12.7$ \\
\hline NWS-16 & $\mathrm{I}$ & 9.2 & 9.2 & 9.2 \\
\hline NWS-16 & $\mathrm{K}$ & 9.8 & 9.8 & 9.8 \\
\hline NWS-16 & $\mathrm{Na}$ & 9.6 & 9.5 & 9.6 \\
\hline NWS-16 & $\mathrm{NO} 2$ & 9.4 & 9.4 & 9.4 \\
\hline NWS-16 & NO3 & 9.5 & 9.5 & 9.5 \\
\hline NWS-16 & $\mathrm{S}$ & 9.3 & 9.2 & 9.3 \\
\hline NWS-16 & $\mathrm{Si}$ & 13.6 & 13.6 & 13.6 \\
\hline NWS-17 & $\mathrm{Al}$ & 12.9 & 12.9 & 12.9 \\
\hline NWS-17 & $\mathrm{Ca}$ & 13.9 & 14.2 & 14.1 \\
\hline NWS-17 & $\mathrm{Cl}$ & $>8.8$ & $>8.8$ & $>8.8$ \\
\hline NWS-17 & $\mathrm{Cr}$ & $>12.5$ & $>12.5$ & $>12.5$ \\
\hline NWS-17 & I & 8.9 & 8.9 & 8.9 \\
\hline NWS-17 & $\mathrm{K}$ & 9.4 & 9.4 & 9.4 \\
\hline NWS-17 & $\mathrm{Na}$ & 9.1 & 9 & 9.1 \\
\hline NWS-17 & $\mathrm{NO} 2$ & 9 & 9 & 9.0 \\
\hline NWS-17 & $\mathrm{NO} 3$ & 9 & 9 & 9.0 \\
\hline NWS-17 & $\mathrm{S}$ & 8.9 & 8.9 & 8.9 \\
\hline NWS-17 & $\mathrm{Si}$ & 13.4 & 13.4 & 13.4 \\
\hline
\end{tabular}


Table D-1. Leach Index Data for the Test Mixes. (continued)

\begin{tabular}{|c|c|c|c|c|}
\hline Identifier & Component & $\begin{array}{c}\text { Leach Index, } \\
\text { Replicate 1 }\end{array}$ & $\begin{array}{c}\text { Leach Index, } \\
\text { Replicate } 2 \\
\end{array}$ & Mean Leach Index \\
\hline NWS-18 & $\mathrm{Al}$ & 12.8 & 12.8 & 12.8 \\
\hline NWS-18 & $\mathrm{Ca}$ & 14 & 13.7 & 13.9 \\
\hline NWS-18 & $\mathrm{Cl}$ & $>9$ & $>9$ & $>9$ \\
\hline NWS-18 & $\mathrm{Cr}$ & $>12.5$ & $>12.5$ & $>12.5$ \\
\hline NWS-18 & I & 9.3 & 9.4 & 9.4 \\
\hline NWS-18 & $\mathrm{K}$ & 9.9 & 10 & 10.0 \\
\hline NWS-18 & $\mathrm{Na}$ & 9.4 & 9.4 & 9.4 \\
\hline NWS-18 & $\mathrm{NO} 2$ & 9.5 & 9.5 & 9.5 \\
\hline NWS-18 & NO3 & 9.3 & 9.3 & 9.3 \\
\hline NWS-18 & $\mathrm{S}$ & 9.3 & 9.3 & 9.3 \\
\hline NWS-18 & $\mathrm{Si}$ & 14 & 13.9 & 14.0 \\
\hline NWS-19 & $\mathrm{Al}$ & 12.7 & 12.8 & 12.8 \\
\hline NWS-19 & $\mathrm{Ca}$ & 14.2 & 14.1 & 14.2 \\
\hline NWS-19 & $\mathrm{Cl}$ & $>8.8$ & $>8.8$ & $>8.8$ \\
\hline NWS-19 & $\mathrm{Cr}$ & $>12.7$ & $>12.7$ & $>12.7$ \\
\hline NWS-19 & I & 8.8 & 8.8 & 8.8 \\
\hline NWS-19 & $\mathrm{K}$ & 9.5 & 9.5 & 9.5 \\
\hline NWS-19 & $\mathrm{Na}$ & 9.4 & 9.4 & 9.4 \\
\hline NWS-19 & $\mathrm{NO} 2$ & 9.1 & 9.1 & 9.1 \\
\hline NWS-19 & NO3 & 9 & 8.9 & 9.0 \\
\hline NWS-19 & $\mathrm{S}$ & 9 & 9 & 9.0 \\
\hline NWS-19 & $\mathrm{Si}$ & 13.7 & 13.6 & 13.7 \\
\hline NWS-20 & $\mathrm{Al}$ & 12.8 & 12.8 & 12.8 \\
\hline NWS-20 & $\mathrm{Ca}$ & 14.3 & 14.4 & 14.4 \\
\hline NWS-20 & $\mathrm{Cl}$ & $>9.1$ & $>9.1$ & $>9.1$ \\
\hline NWS-20 & $\mathrm{Cr}$ & $>12.6$ & $>12.6$ & $>12.6$ \\
\hline NWS-20 & $\mathrm{I}$ & 9.2 & 9.2 & 9.2 \\
\hline NWS-20 & $\mathrm{K}$ & 9.7 & 9.7 & 9.7 \\
\hline NWS-20 & $\mathrm{Na}$ & 9.5 & 9.4 & 9.5 \\
\hline NWS-20 & NO2 & 9.4 & 9.4 & 9.4 \\
\hline NWS-20 & NO3 & 9.4 & 9.3 & 9.4 \\
\hline NWS-20 & $\mathrm{S}$ & 9.2 & 9.2 & 9.2 \\
\hline NWS-20 & $\mathrm{Si}$ & 13.6 & 13.5 & 13.6 \\
\hline
\end{tabular}


SRNL-STI-2013-00499

Revision 0

Appendix E. Least Squares Regression Analyses

E-1 
Exhibit E-1. Summary of Least Squares Regression Analysis of Slurry Temperature Rise Data.

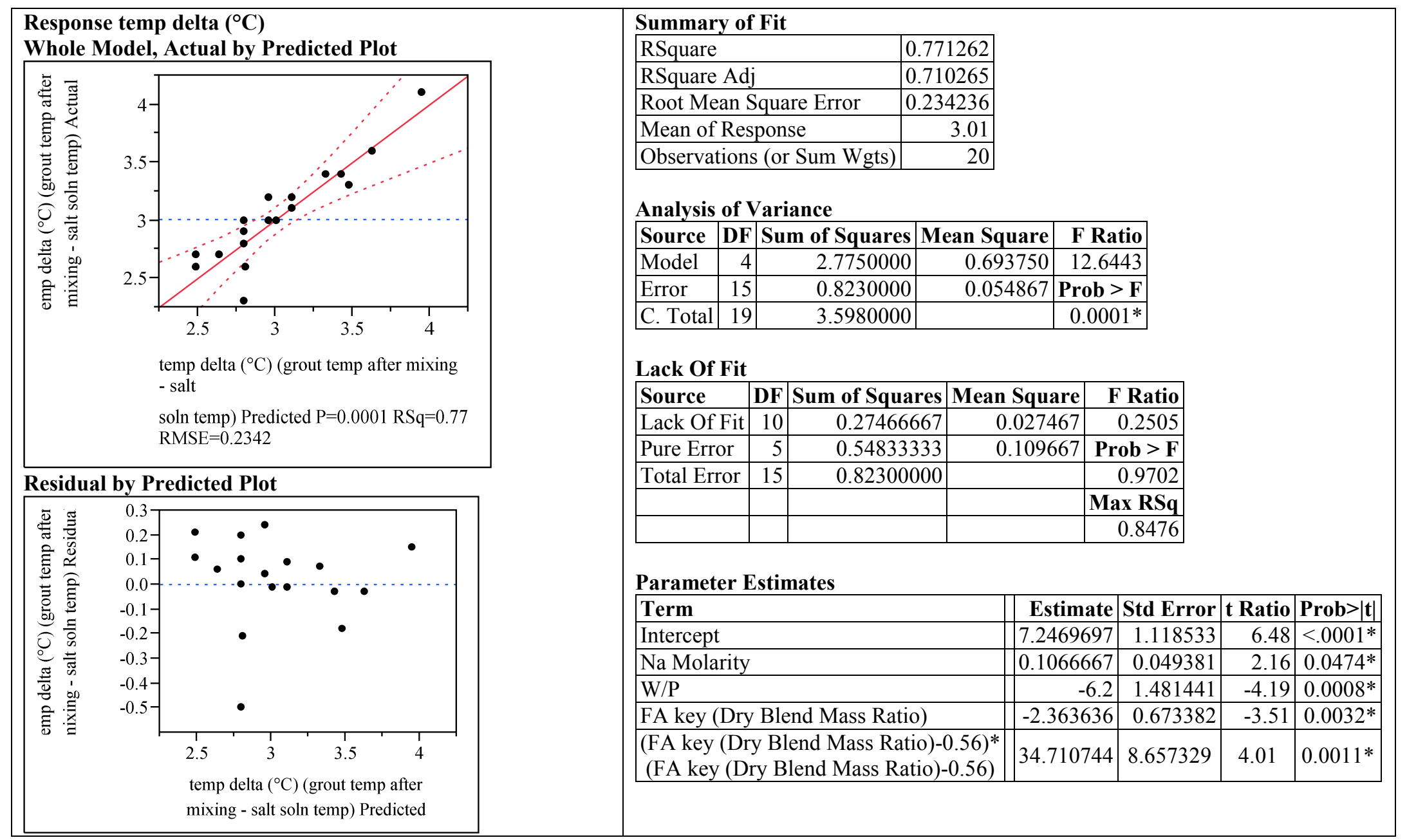


Exhibit E-2. Summary of Least Squares Regression Analysis of Yield Stress Data.

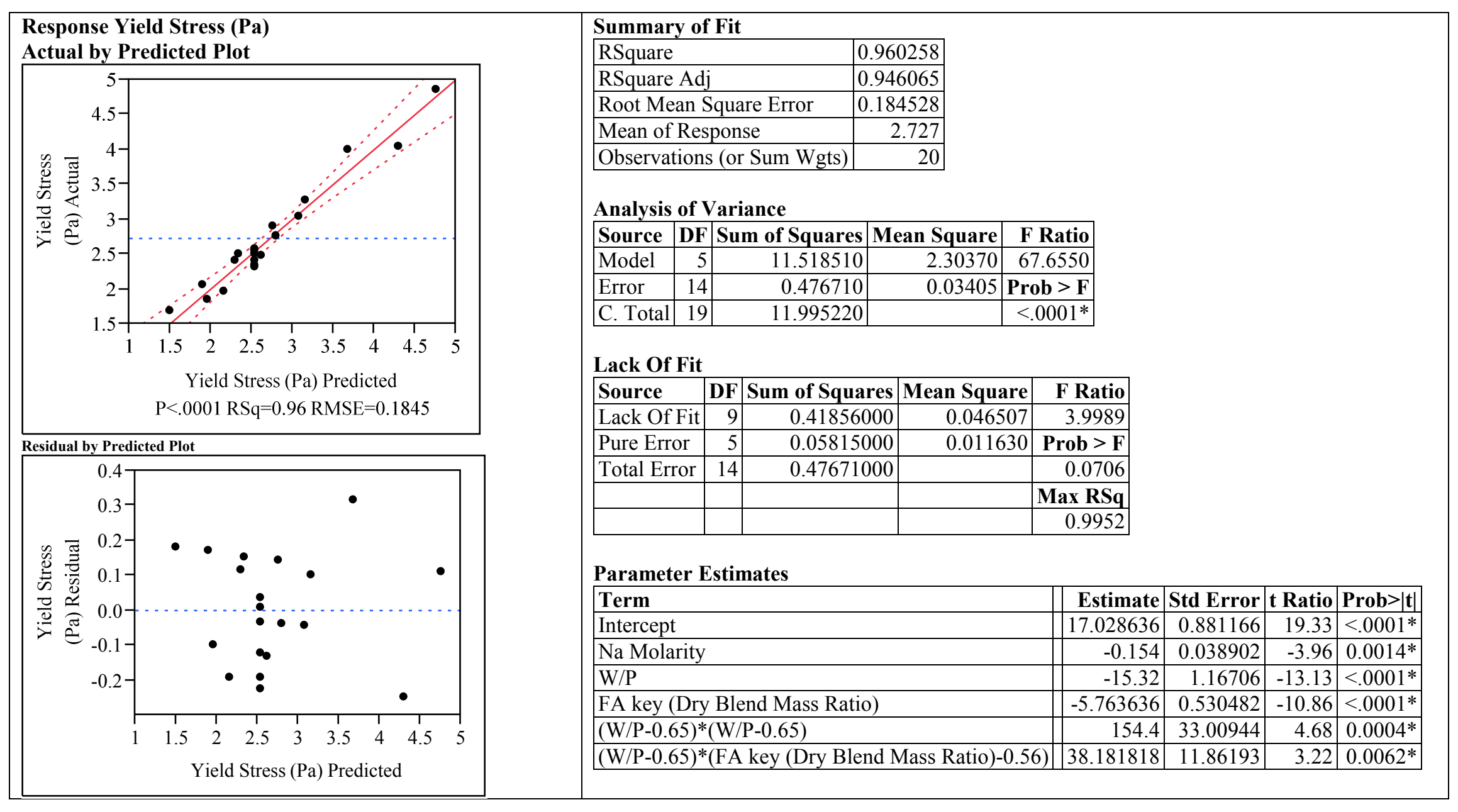


Exhibit E-3. Summary of Least Squares Regression Analysis of Plastic Viscosity Data.

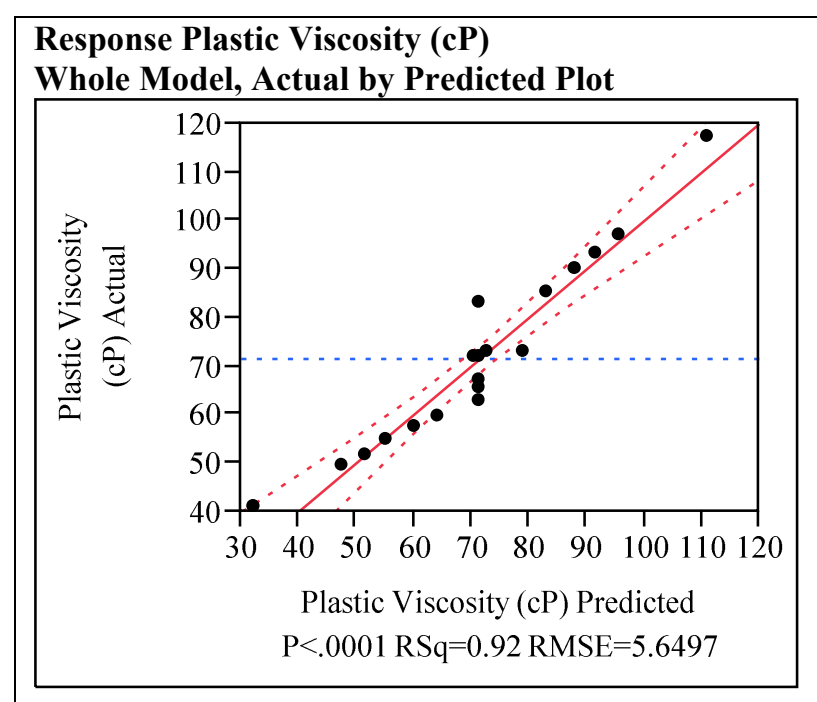

\section{Residual by Predicted Plot}

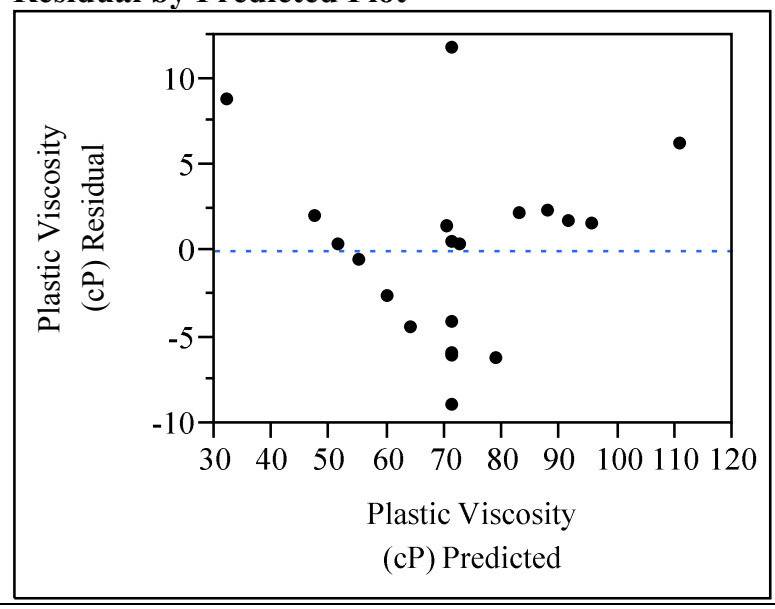

Summary of Fit
\begin{tabular}{|l|r|}
\hline RSquare & 0.921374 \\
\hline RSquare Adj & 0.906632 \\
\hline Root Mean Square Error & 5.649746 \\
\hline Mean of Response & 71.6 \\
\hline Observations (or Sum Wgts) & 20 \\
\hline
\end{tabular}

Analysis of Variance

\begin{tabular}{|l|r|r|r|r|}
\hline Source & DF & Sum of Squares & Mean Square & F Ratio \\
\hline
\end{tabular}

\begin{tabular}{|l|r|r|r|r|}
\hline Model & 3 & 5984.7660 & 1994.92 & 62.4983 \\
\hline Error & 16 & 510.7140 & 31.92 & Prob > F \\
\hline C. Tota & 19 & 6495.4800 & & $<.0001^{*}$ \\
\hline
\end{tabular}

\begin{tabular}{|l|r|r|r|r|}
\hline C. Total & 19 & 6495.4800 & & $<.0001^{*}$ \\
\hline
\end{tabular}

Lack Of Fit
\begin{tabular}{|l|r|r|r|r|}
\hline Source & DF & Sum of Squares & Mean Square & F Ratio \\
\hline Lack Of Fit & 11 & 229.66067 & 20.8782 & 0.3714 \\
\hline Pure Error & 5 & 281.05333 & 56.2107 & Prob $>$ F \\
\hline Total Error & 16 & 510.71400 & & 0.9206 \\
\hline & & & & Max RSq \\
\hline & & & & 0.9567 \\
\hline
\end{tabular}

Parameter Estimates

\begin{tabular}{|l|r|r|r|r|}
\hline Term & Estimate & Std Error & t Ratio & Prob $>|\mathbf{t}|$ \\
\hline Intercept & 145.03 & 26.94925 & 5.38 & $<.0001^{*}$ \\
\hline Na Molarity & 13.48 & 1.191071 & 11.32 & $<.0001^{*}$ \\
\hline W/P & -229.8 & 35.73213 & -6.43 & $<.0001^{*}$ \\
\hline FA key (Dry Blend Mass Ratio) & -69 & 16.24188 & -4.25 & $0.0006^{*}$ \\
\hline
\end{tabular}


Exhibit E-4. Summary of Least Squares Regression Analysis of Fresh Density Data.

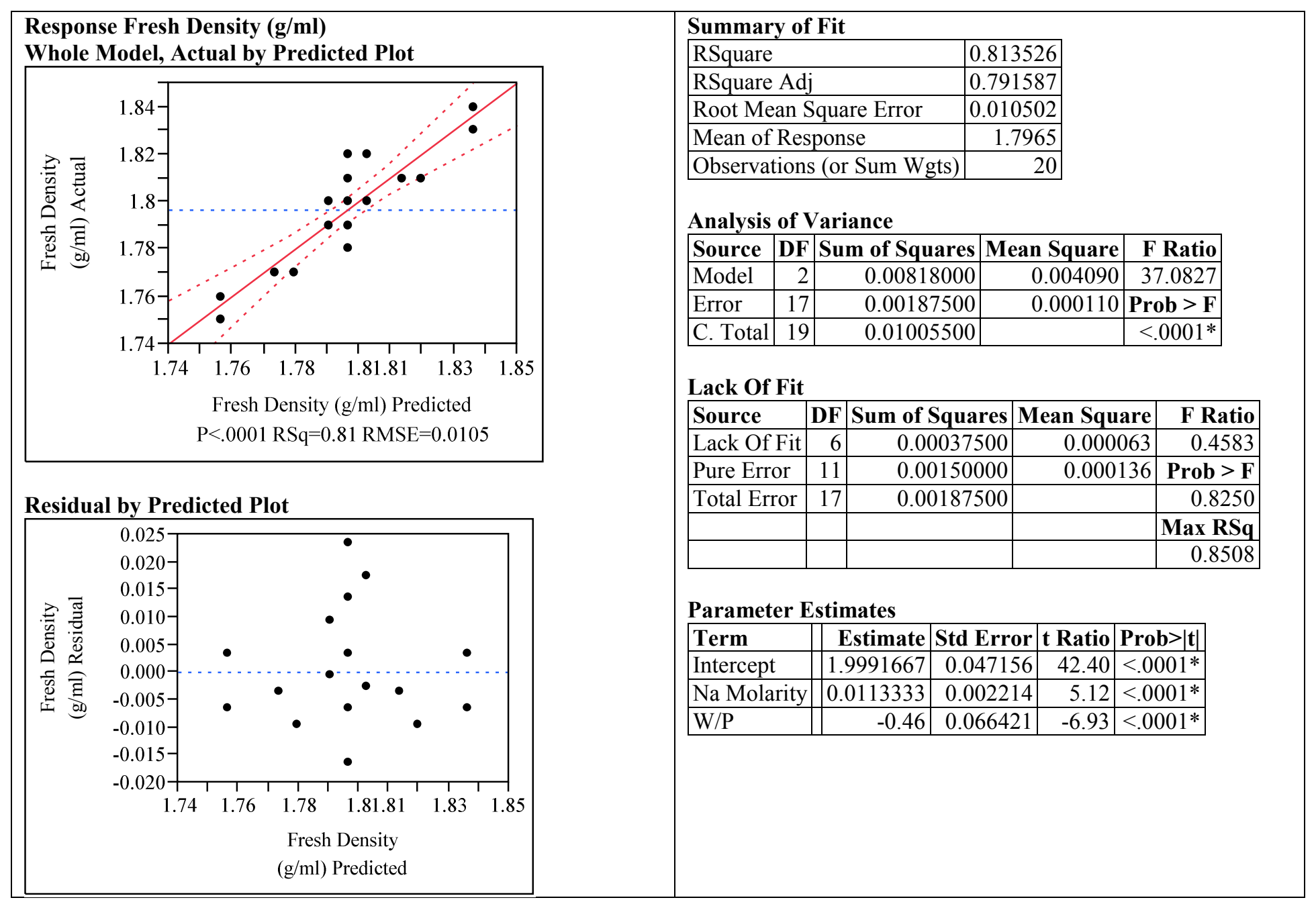


Exhibit E-5. Summary of Least Squares Regression Analysis of Cured Density Data.

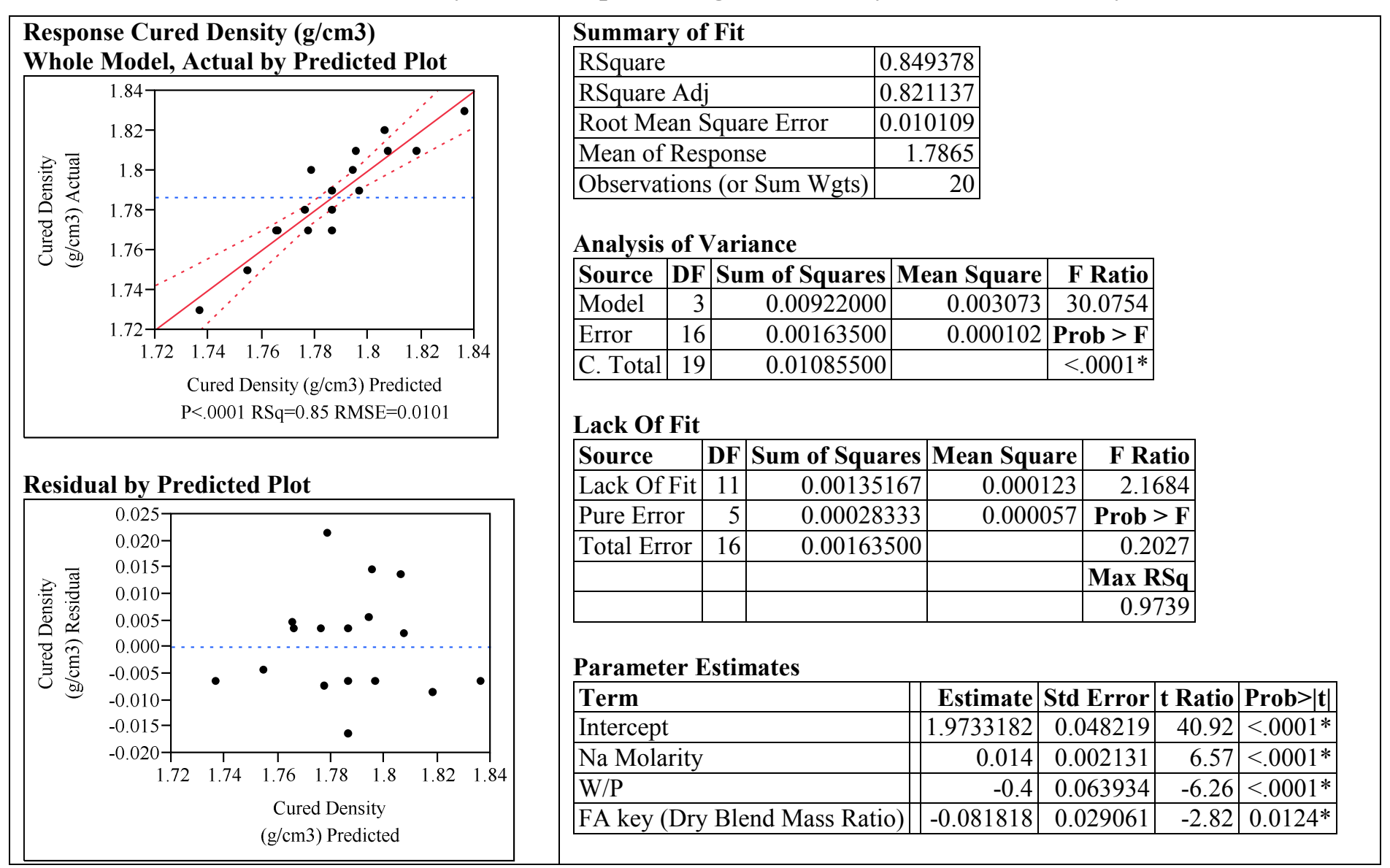


Exhibit E-6. Summary of Least Squares Regression Analysis of Porosity Data.

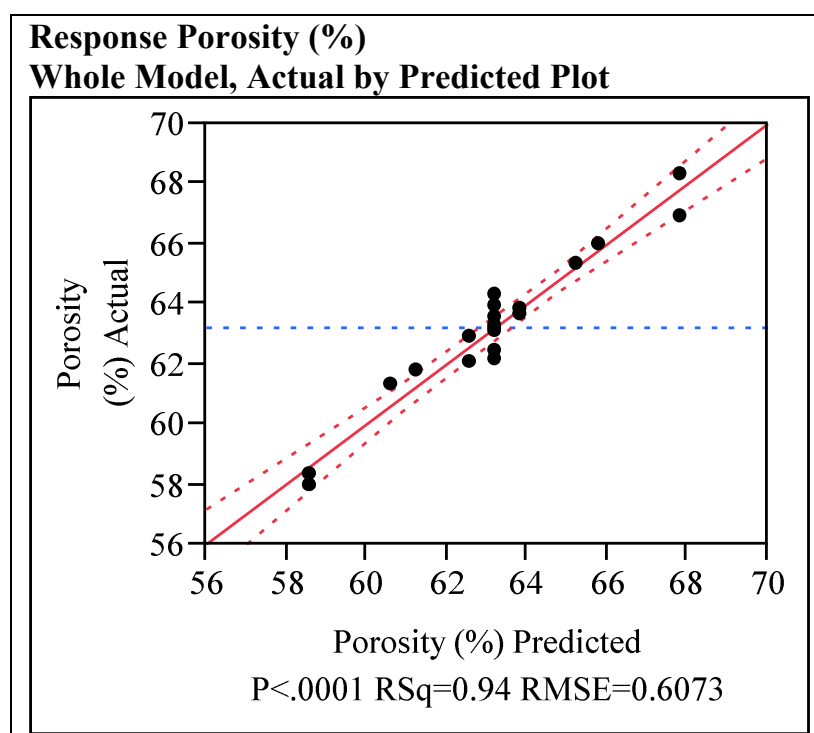

Residual by Predicted Plot

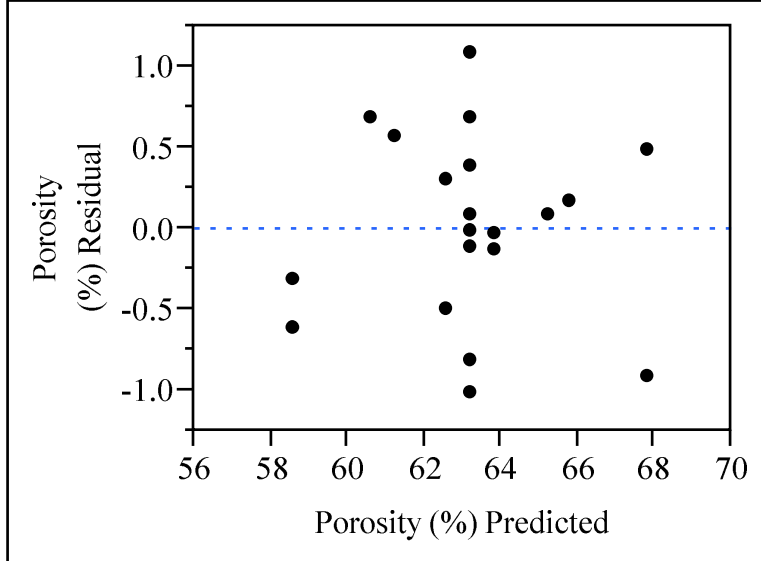

Summary of Fit
\begin{tabular}{|l|r|}
\hline RSquare & 0.944996 \\
\hline RSquare Adj & 0.938525 \\
\hline Root Mean Square Error & 0.607308 \\
\hline Mean of Response & 63.22 \\
\hline Observations (or Sum Wgts) & 20 \\
\hline
\end{tabular}

Analysis of Variance

\begin{tabular}{|l|r|r|r|r|}
\hline Source & DF & Sum of Squares & Mean Square & F Ratio \\
\hline
\end{tabular}

\begin{tabular}{|l|r|r|r|r|}
\hline Model & 2 & 107.72200 & 53.8610 & 146.0346 \\
\hline Error & 17 & 6.27000 & 0.3688 & Prob $>$ F \\
\hline C.
\end{tabular}

\begin{tabular}{l|r|r|r|r|}
\hline C. Total & 19 & 113.99200 & 0.3688 & Prob \\
\hline
\end{tabular}

\section{Lack Of Fit}

\begin{tabular}{|l|r|r|r|r|}
\hline Source & DF & Sum of Squares & Mean Square & F Ratio \\
\hline Lack Of Fit & 6 & 1.4200000 & 0.236667 & 0.5368 \\
\hline Pure Error & 11 & 4.8500000 & 0.440909 & Prob $>$ F \\
\hline Total Error & 17 & 6.2700000 & & 0.7702 \\
\hline & & & & Max RSq \\
\hline & & & & 0.9575 \\
\hline
\end{tabular}

Parameter Estimates

\begin{tabular}{|l||l|l|l|l|}
\hline Term & Estimate & Std Error & t Ratio & Prob $>|\mathbf{t}|$ \\
\hline
\end{tabular}

\begin{tabular}{|l|r|r|r|r|l|}
\hline Intercept & 22.56 & 2.726883 & 8.27 & $<.0001^{*}$ \\
\hline Na Molarity & 1.74 & 0.128032 & 13.59 & $<.0001^{*}$ \\
\hline W/P & 39.8 & 3.840956 & 10.36 & $<.0001^{*}$ \\
\hline
\end{tabular}

$\mathrm{W} / \mathrm{P}$ 
Exhibit E-7. Summary of Least Squares Regression Analysis of Time to Peak Heat Flow Data.

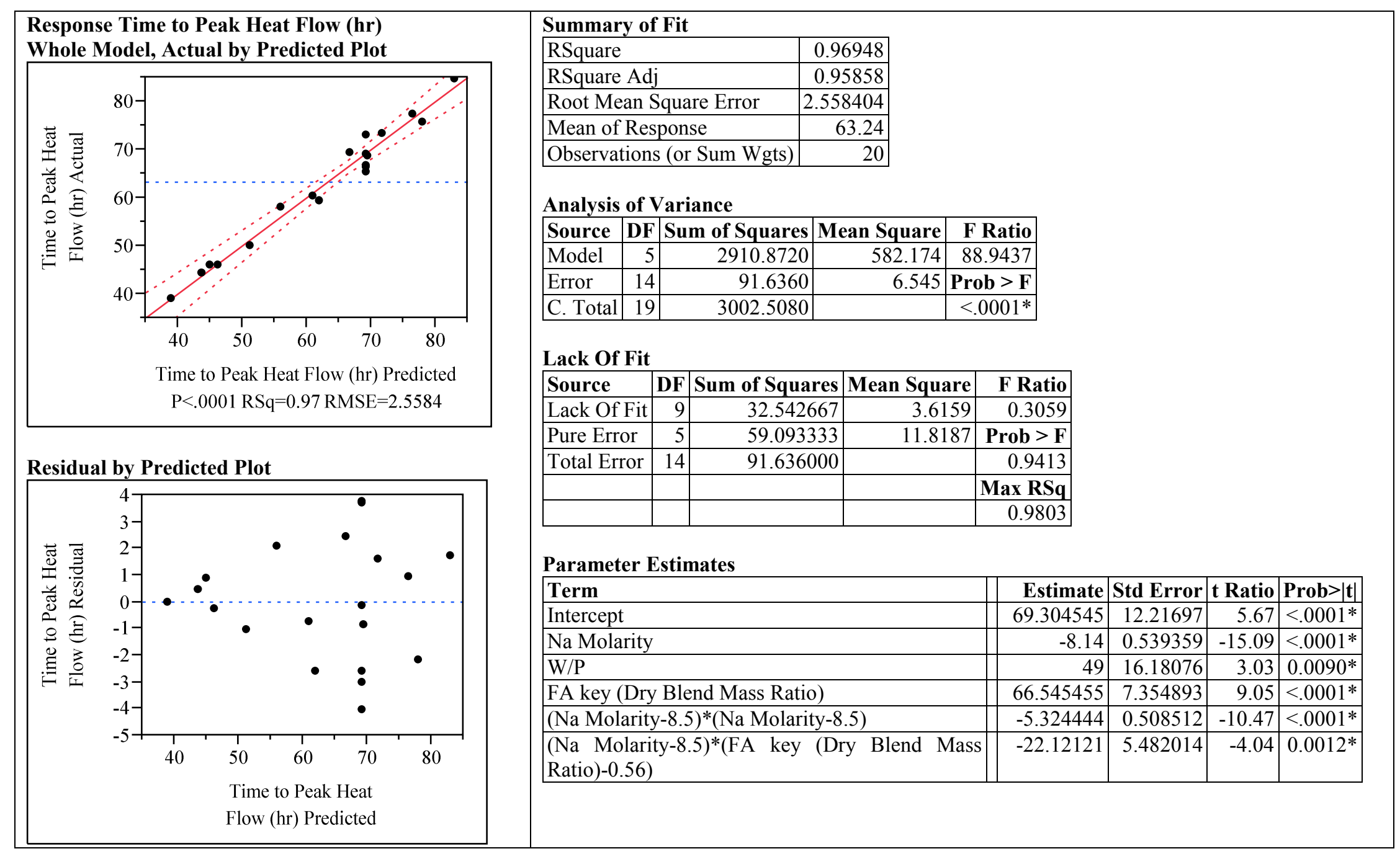


Exhibit E-8. Summary of Least Squares Regression Analysis of Peak Normalized Heat Flow Data.

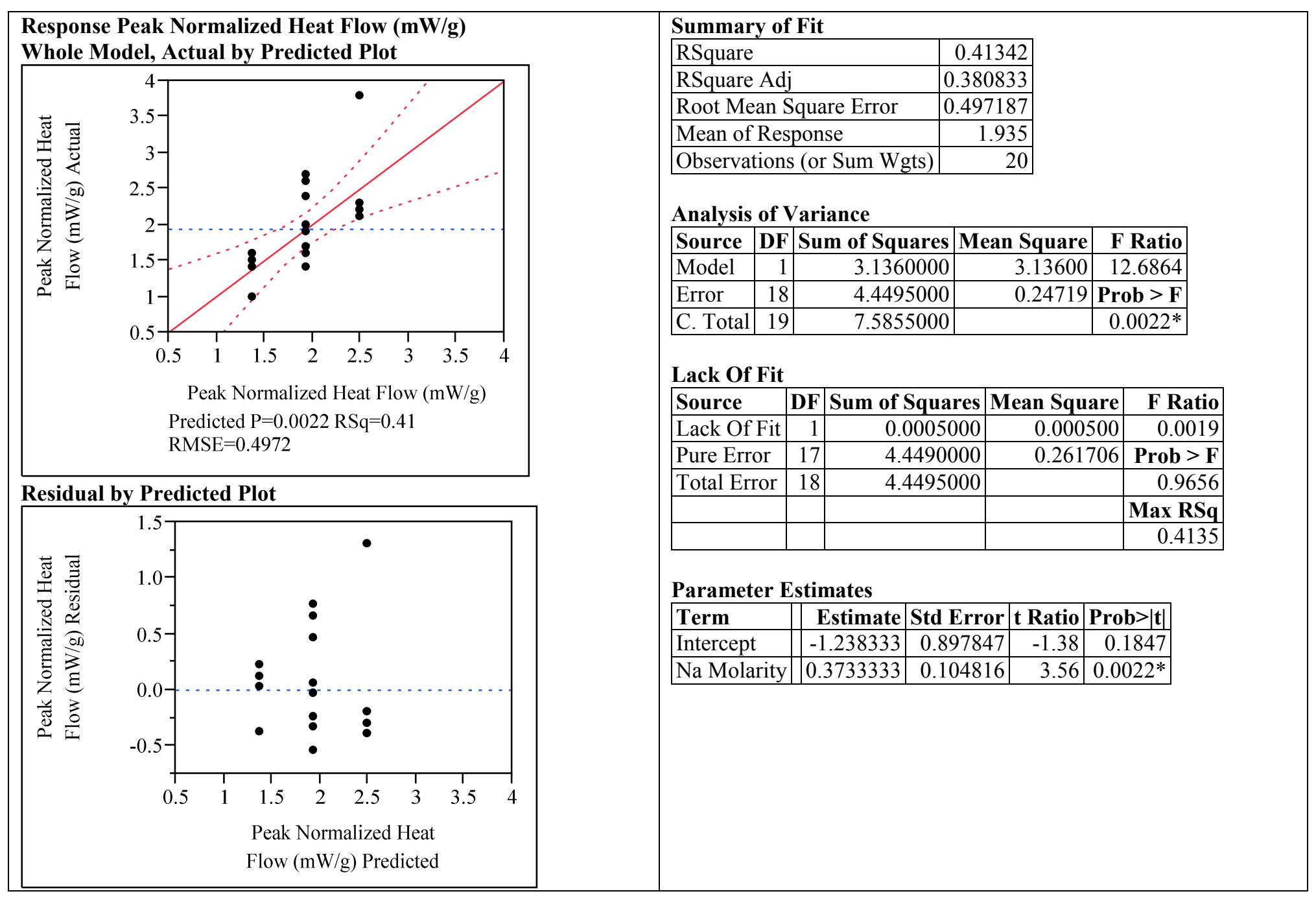


Exhibit E-9. Summary of Least Squares Regression Analysis of Normalized Heat Data.

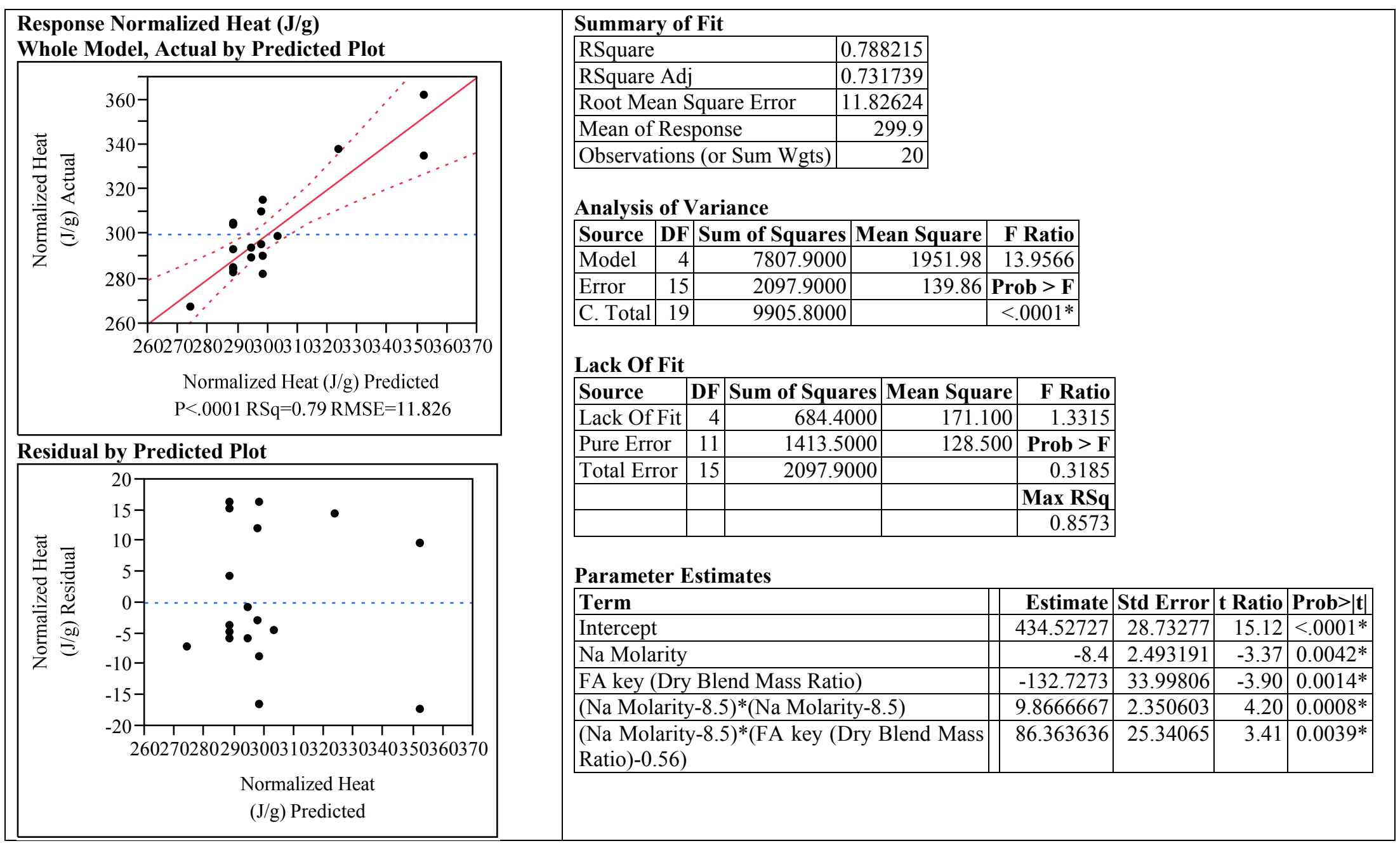


Exhibit E-10. Summary of Least Squares Regression Analysis of 28 Day Compressive Strength Data.

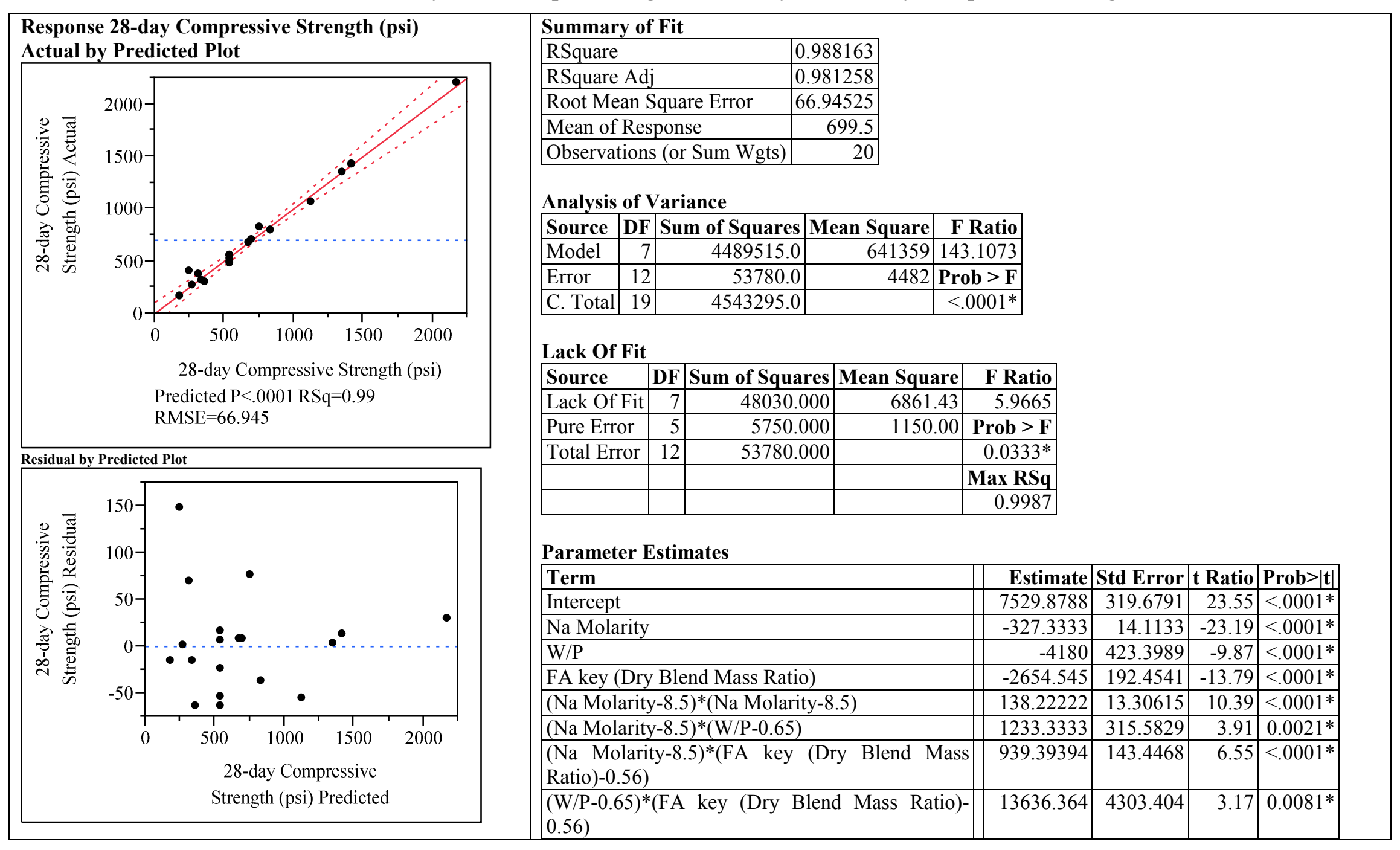


Exhibit E-11. Summary of Least Squares Regression Analysis of 90 Day Compressive Strength Data.

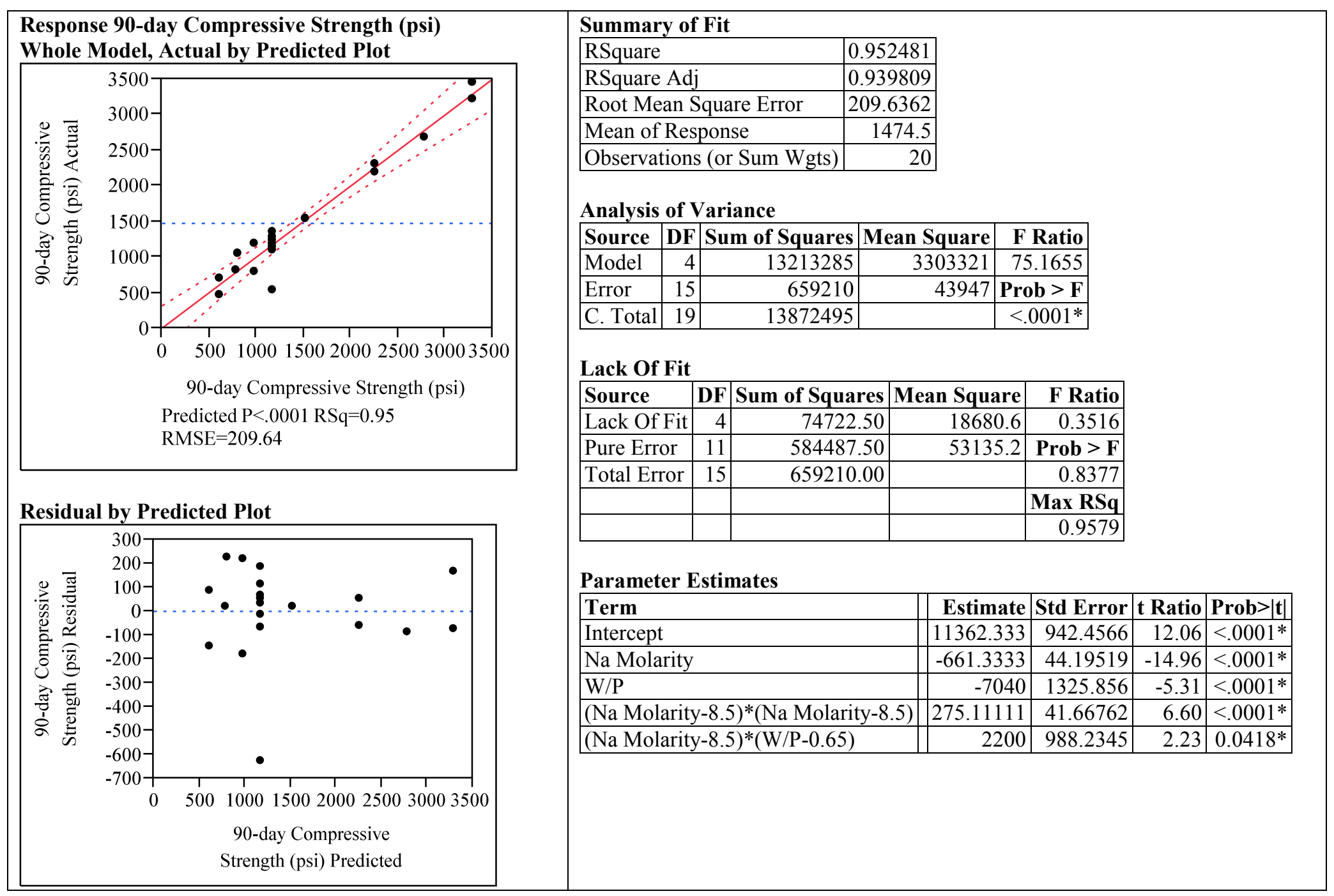


Exhibit E-12. Summary of Least Squares Regression Analysis of Nitrate Leach Index Data.

\begin{tabular}{|c|c|c|c|c|c|c|c|c|c|c|c|}
\hline \multirow{2}{*}{\multicolumn{2}{|c|}{$\begin{array}{l}\text { Response Leach Index NO3 } \\
\text { Whole Model, Actual by Predicted Plot }\end{array}$}} & \multicolumn{10}{|c|}{ Summary of Fit } \\
\hline & & \multicolumn{3}{|l|}{ RSquare } & \multicolumn{2}{|c|}{0.823729} & & & & & \\
\hline \multirow{12}{*}{ 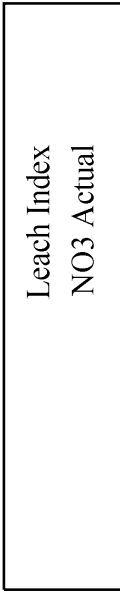 } & \multirow{12}{*}{ 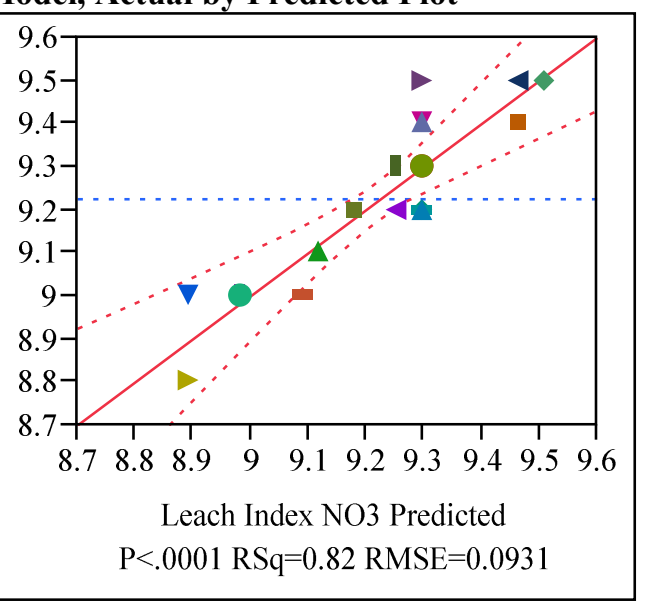 } & \multicolumn{3}{|l|}{ RSquare Adj } & \multicolumn{2}{|c|}{0.776723} & & & & & \\
\hline & & \multicolumn{3}{|c|}{ Root Mean Square Error } & \multicolumn{2}{|c|}{0.093095} & & & & & \\
\hline & & \multicolumn{3}{|c|}{ Mean of Response } & \multicolumn{2}{|c|}{9.225} & & & & & \\
\hline & & \multicolumn{3}{|c|}{ Observations (or Sum Wgts) } & \multicolumn{2}{|r|}{20} & & & & & \\
\hline & & \multicolumn{7}{|c|}{ Analysis of Variance } & & & \\
\hline & & \begin{tabular}{|l|l|} 
Source & DF \\
\end{tabular} & SuI & m of Squares & \multicolumn{2}{|c|}{ s Mean Square } & \multicolumn{2}{|c|}{ F Ratio } & & & \\
\hline & & Model & & 0.60750000 & & 0.151875 & \multicolumn{2}{|c|}{17.5240} & & & \\
\hline & & Error & & 0.13000000 & & 0.008667 & \multicolumn{2}{|c|}{ Prob $>$ F } & & & \\
\hline & & \begin{tabular}{|l|l|} 
C. Total & 19 \\
\end{tabular} & & 0.73750000 & & & \multicolumn{2}{|c|}{$<.0001 *$} & & & \\
\hline & & \multicolumn{7}{|l|}{ Lack Of Fit } & & & \\
\hline & & \begin{tabular}{|l|l} 
Source & 1 \\
\end{tabular} & DF & Sum of Squz & Iares & Mean Squ & are & F Ratio & & & \\
\hline & & \begin{tabular}{|l|} 
Lack Of Fit \\
\end{tabular} & 4 & 0.01125 & 5000 & 0.0028 & 812 & 0.2605 & & & \\
\hline \multirow{2}{*}{\multicolumn{2}{|c|}{ Residual by Predicted Plot }} & \begin{tabular}{|l|} 
Pure Error \\
\end{tabular} & 11 & 0.11875 & 5000 & $0.010^{\prime}$ & 795 & Prob $>$ F & & & \\
\hline & & \multirow[t]{2}{*}{\begin{tabular}{|l|} 
Total Error \\
\end{tabular}} & 15 & 0.13000 & 0000 & & & 0.8972 & & & \\
\hline \multirow{10}{*}{ 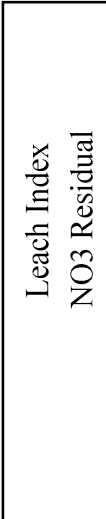 } & 0.25 & & & & & & & Max RSq & & & \\
\hline & $0.20-$ & & & & & & & 0.8390 & & & \\
\hline & $0.15-$ & \multicolumn{10}{|c|}{ Parameter Estimates } \\
\hline & $0.10-$ & \multicolumn{5}{|l|}{ Term } & & Estimate & Std Error & t Ratio & Prob $>|t|$ \\
\hline & $0.05-$ & \multicolumn{5}{|l|}{ Intercept } & & 0.199091 & 0.226181 & 45.09 & $<.0001 *$ \\
\hline & 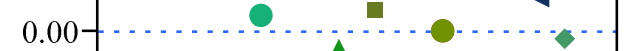 & \multicolumn{5}{|l|}{\begin{tabular}{|l|} 
Na Molarity \\
\end{tabular}} & & 0.02 & 0.019626 & 1.02 & 0.3243 \\
\hline & $-0.05-$ & \multicolumn{5}{|c|}{ FA key (Dry Blend Mass Ratio) } & & 1.909091 & 0.267629 & -7.13 & $<.0001 *$ \\
\hline & $-0.00]$ & \multicolumn{5}{|c|}{$(\mathrm{Na}$ Molarity-8.5)*(Na Molarity-8.5) } & & 0.066667 & 0.018504 & -3.60 & $0.0026^{*}$ \\
\hline & 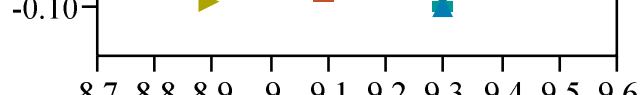 & $\begin{array}{l}\text { (Na Molarit } \\
\text { Mass Ratio)- }\end{array}$ & $\begin{array}{l}\text { ty-8 } \\
-0.56\end{array}$ & $\begin{array}{l}.5)^{*}(\mathrm{FA} \mathrm{key} \\
6)\end{array}$ & y $(D$ & Ory Blend & & 0.454545 & 0.199479 & -2.28 & $0.0377^{*}$ \\
\hline & Leach Index NO3 Predicted & & & & & & & & & & \\
\hline
\end{tabular}




\section{Distribution:}

J. W. Amoroso, 999-W

D. R. Best, 999-W

T. B. Brown, 773-A

D. R. Click, 999-W

A. D. Cozzi, 999-W

W. E. Daniel, 999-W

T. B. Edwards, 999-W

R. E. Eibling, 999-W

S. D. Fink, 773-A

K. M. Fox, 999-W

E. K. Hansen, 999-W

C. C. Herman, 773-A

E. N. Hoffman, 999-W

C. A. Langton, $773-43 \mathrm{~A}$

P. L. Lee, 703-41A

S. L. Marra, 773-A

F. M. Pennebaker, 773-42A

M. M. Reigel, 999-W

W. T. Riley, 999-W

K. A. Roberts, 773-43A

S. P. Simner, $249-8 \mathrm{H}$

S. A. Smith, 705-1C

A. V. Staub, 704-Z

K. H. Subramanian, 241-156H

W. R. Wilmarth, 773-A

Records Administration (EDWS)
S. L. Charboneau, DOE-ORP

J. A. Diediker. DOE-ORP

T. W. Fletcher, DOE-ORP

B. J. Harp, DOE-ORP

C. C. Harrington, DOE-ORP

S. Pfaff, DOE-ORP

A. V. Arakali, WTP

S. M. Barnes, WTP

P. A. Benson, WTP

G. M. Duncan, WTP

S. T. Arm, WRPS

C. Burrows, WRPS

T. W. Crawford, WRPS

W. G. Ramsey, WRPS

R. A. Robbins, WRPS

P. L. Rutland, WRPS

S. A. Saunders, WRPS

D. J. Swanberg, WRPS

M. G. Thien, WRPS

C.A. Brown, PNNL

R. D. Peterson, PNNL

R. J. Serne, PNNL

J. H. Westsik, PNNL 